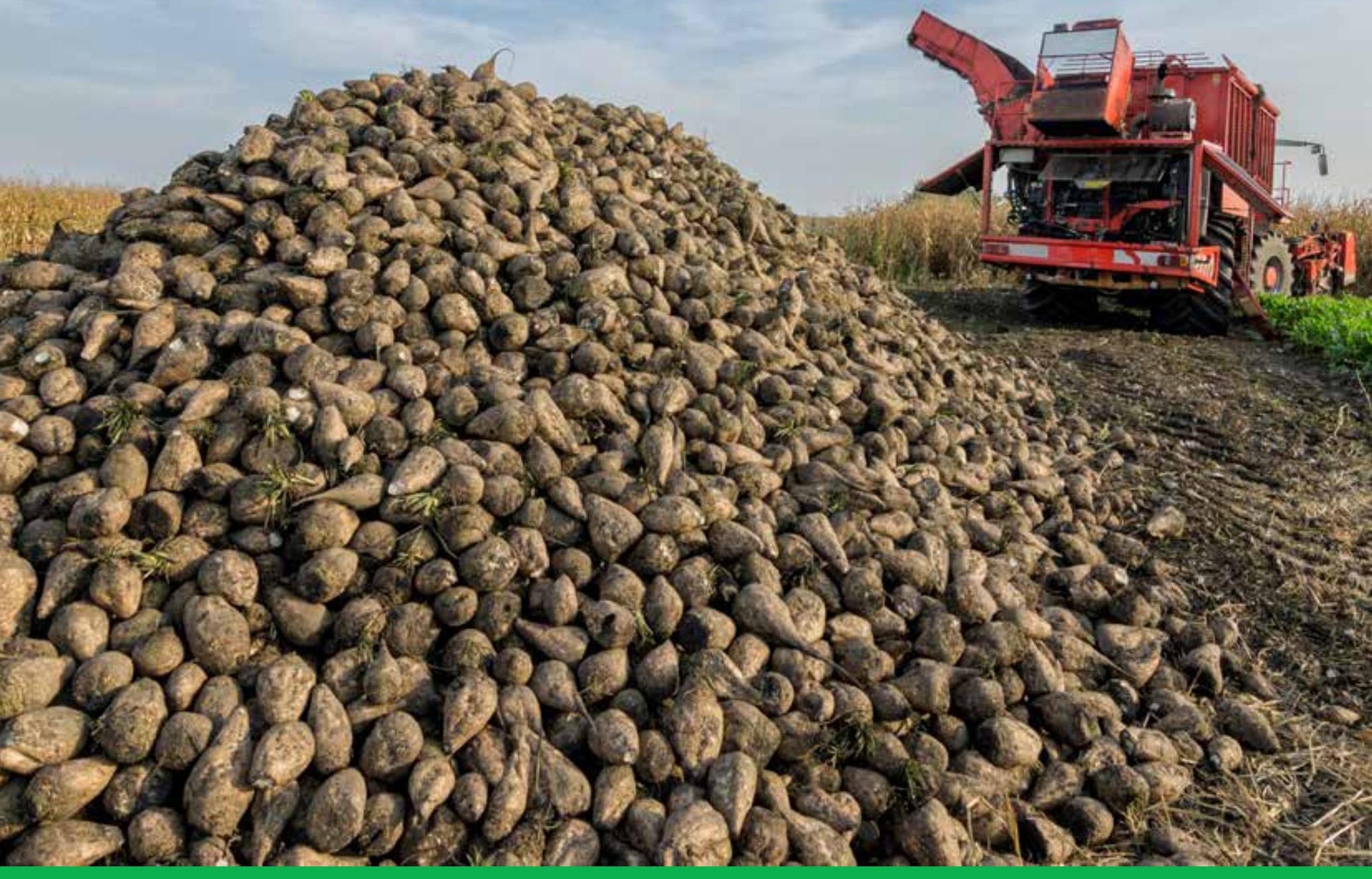

\title{
Impact of coupled EU support for sugar beet growing: More production, lower prices
}





\section{Impact of coupled EU support for sugar beet growing: More production, lower prices}

A.B. Smit, R.A. Jongeneel, H. Prins, J.H. Jager and W.H.G.J. Hennen

This study was carried out by Wageningen Economic Research and was commissioned and financed by Wirtschaftliche Vereinigung Zucker e.V. (WVZ) in Bonn

Wageningen Economic Research

Wageningen, December 2017

REPORT

2017-114

ISBN 978-94-6343-243-6 
Smit, A.B., R.A. Jongeneel, H. Prins, J.H. Jager and W.H.G.J. Hennen o, 2017. Impact of coupled support for sugar beet growing in the EU: More sugar beets and lower sugar beet price. Wageningen, Wageningen Economic Research, Report 2017-114. 62 pp.; 12 fig.; 11 tab.; 16 ref.

Sinds de onderhandelingen over het 'nieuwe GLB' (Gemeenschappelijk Landbouwbeleid van de EU) is het mogelijk vrijwillige gekoppelde steun (voluntary coupled support, VCS) aan de teelt van suikerbieten te geven. Sinds 2015 maken tien en sinds 2017 elf EU-lidstaten daar gebruik van. In 2017 werd het EU suikerquotasysteem afgeschaft. Dat is een grote verandering voor de EU suikersector, die tot meer concurrentie tussen suikerbedrijven leidt en tot sterker variërende suikerprijzen dan voorheen. In een dergelijke dynamische context zijn vragen gesteld over de mogelijke productie- en marktverstorende effecten en de legitimiteit van een VCS-regeling.

In the 2013 negotiations on the 'new CAP' (Common Agricultural Policy), the option of voluntary coupled support (VCS) for sugar beet growing was introduced, which has been implemented from 2015 onwards by ten and from 2017 by eleven Member States. In 2017, a great change took place in the EU sugar sector through the abolishment of the sugar quota system, leading to an increase of competition between sugar companies and more fluctuating sugar prices than before. In such a dynamic context, questions were raised about potentially destabilising production and market effects of a VCS-regulation and about its legitimacy.

Key words: sugar, beets, CAP, Common Agricultural Policy, voluntary coupled support, VCS

This report can be downloaded for free at https://doi.org/10.18174/430039 or at www.wur.eu/economic-research (under Wageningen Economic Research publications).

(C) 2017 Wageningen Economic Research

P.O. Box 29703, 2502 LS The Hague, The Netherlands, T +31 (0)70 3358330 ,

E communications.ssg@wur.nl, http://www.wur.eu/economic-research. Wageningen Economic Research is part of Wageningen University \& Research.

\section{(cc) BY-NC}

For its reports, Wageningen Economic Research utilises a Creative Commons Attributions 3.0 Netherlands license.

(c) Wageningen Economic Research, part of Stichting Wageningen Research, 2017

The user may reproduce, distribute and share this work and make derivative works from it. Material by third parties which is used in the work and which are subject to intellectual property rights may not be used without prior permission from the relevant third party. The user must attribute the work by stating the name indicated by the author or licensor but may not do this in such a way as to create the impression that the author/licensor endorses the use of the work or the work of the user. The user may not use the work for commercial purposes.

Wageningen Economic Research accepts no liability for any damage resulting from the use of the results of this study or the application of the advice contained in it.

Wageningen Economic Research is ISO 9001:2008 certified.

Wageningen Economic Research Report 2017-114 | Project code 2282200296

Cover photo: Shutterstock 


\section{Contents}

Preface $\quad 5$

$\begin{array}{ll}\text { Executive summary } & 6\end{array}$

1

$\begin{array}{ll}\text { Introduction } & 9\end{array}$

1.1 Context 9

$\begin{array}{ll}1.2 \text { Aim of the research } & 10\end{array}$

$\begin{array}{lll}1.3 & \text { Research questions } & 10\end{array}$

1.4 Scope 11

1.5 Contents of the report $\quad 11$

$\begin{array}{ll}\text { Methodology } & 12\end{array}$

2.1 Assessing the competitiveness of sugar beet production in the VCS-MSs 12

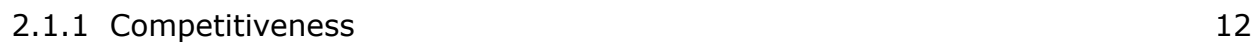

2.1.2 Standard Outputs as a basis for competitiveness analysis $\quad 13$

2.2 Model calculations with an equilibrium displacement model (EDM) 14

2.2.1 The EDM modelling approach $\quad 15$

2.2.2 Model calibration and base year data 16

$\begin{array}{llr}3 & \text { Current situation } & 18\end{array}$

3.1 Large shifts in sugar beet areas in the EU since $2005 \quad 18$

3.2 Sixty relevant regions within the VCS-MSs 19

$\begin{array}{lll}3.3 & \text { VCS-support levels very different in different MSs } & 21\end{array}$

3.4 Large number of small sugar beet growers in VCS-MSs $\quad 24$

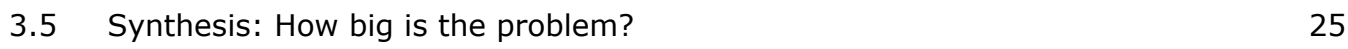

3.5.1 VCS support for sugar beet in perspective $\quad 25$

3.5.2 VCS support changes direct support levels in relevant regions $\quad 26$

$4 \quad$ Sugar beet as a competitive crop $\quad 27$

4.1 Comparison of SOs in different MSs and specifically in VCS-MSs 27

4.1.1 Results of the comparison $\quad 27$

4.1.2 Discussion of the SO-comparison method 29

4.2 Other reasons for VCS support in different countries? 30

4.2.1 Low yields 30

4.2.2 Low prices 31

4.2.3 Low sugar beet farmer incomes $\quad 32$

$\begin{array}{lll}4.3 & \text { Conclusions } & 33\end{array}$

$5 \quad$ Modelling and VCS impact analysis $\quad 34$

$\begin{array}{lll}5.1 & \text { Introduction } & 34\end{array}$

5.2 Coupled support impact simulation $\quad 34$

$\begin{array}{lll}5.3 & \text { Concluding remarks } & 36\end{array}$ 
$\begin{array}{lll}6.1 & \text { Introduction } & 38\end{array}$

6.2 Legal conditions and VCS support implementation 38

6.3 VCS and the basic EU-principle of a level playing field 39

6.4 Exit in 2006 and come back in business with VCS? 39

6.5 VCS effects in 'weak' and stronger regions 40

6.6 VCS application without adverse production and market effects 40

$\begin{array}{lll}6.7 & \text { Differences between sugar beet and other crops? } & 40\end{array}$

$\begin{array}{ll}6.8 \text { Concluding remarks } & 41\end{array}$

$\begin{array}{ll}\text { Conclusions and recommendations } & 42\end{array}$

$\begin{array}{lll}7.1 & \text { Current situation } & 42\end{array}$

7.2 Production costs of sugar beet growing in VCS- and other MSs 42

7.3 Effects of VCS support on sugar beet areas and the EU-sugar market 42

$\begin{array}{lll}7.4 & \text { Legitimacy of national or regional VCS-support } & 43\end{array}$

$\begin{array}{lll}7.5 & \text { Recommendations } & 43\end{array}$

References and websites $\quad 45$

Appendix $1 \quad$ Sugar beet areas in the EU in different MSs over time $\quad 46$

Appendix 2 Voluntary Coupled Support amounts for sugar beet for $\begin{array}{ll}\text { the MSs involved } & 47\end{array}$

Appendix 3 Characteristics of the 60 most relevant regions in the ten VCS-MSs

Appendix 4 Distribution of sugar beet areas per farm in the VCS-MSs (in 2013)

Appendix 5 Distribution of sugar beet areas over area categories in the VCS-MSs (in 2013)

Appendix 6 Sugar beet areas in the VCS-MSs and in the regions in these MSs with the largest area in 2013

Appendix 7 Sugar beet area distribution in the regions in the VCS-MSs with the largest area in 2013

Appendix 8 Standard Outputs (2010) of sugar beets and alternative crops in some important sugar beet production regions (VCS-MSs)

Appendix 9 Sugar beet yields in the EU in 2011 until 2015

Appendix 10 Regional indicators for evaluation of VCS-support in ten VCS-MSs 


\section{Preface}

In the EU, sugar beet is a major arable crop (1.3 million ha in 2015), the largest crop after cereals, rapeseed and potatoes. The EU sugar sector has gone through great changes due the great Sugar Reform in 2006. In 2017, the EU sugar sector went through another great change again through the abolishment of the sugar quota system. In different years, the EU sugar beet area already has increased in anticipation of a quota-free era. Meanwhile, the sugar industry has been working on cost price reduction, anticipating an increase of competition between sugar companies and more fluctuating sugar prices than before.

In the 2013 negotiations on the 'new CAP' (Common Agricultural Policy), the option of voluntary coupled support (VCS) for sugar beet growing was introduced, which has been implemented from 2015 onwards by ten MSs (and from 2017 by eleven MSs). In the dynamic context of quota abolishment, questions could be raised about potentially destabilising production and market effects of such a VCS regulation and about its legitimacy. Wageningen Economic Research studied these questions on request of the Wirtschaftliche Vereinigung Zucker e.V. (WVZ) in Bonn. This report provides the answers to the questions raised after studying the regulation and the data and modelling the effects of VCS on sugar beet production and price.

We want to thank WVZ for their request and for the excellent cooperation with the WVZ office and the supervising 'Arbeitsgruppe Marktordnung'.

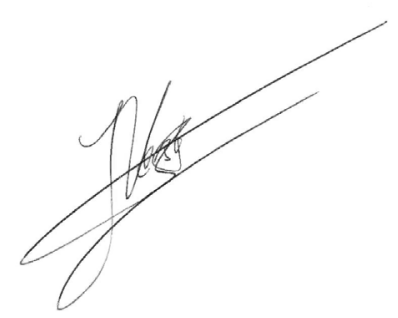

Prof.dr.ir. J.G.A.J. (Jack) van der Vorst General Director Social Sciences Group (SSG)

Wageningen University \& Research 


\section{Executive summary}

Introduction - dynamics in EU sugar beet growing since 2005

In the EU, sugar beet is a major arable crop (1.3 million ha in 2015), the largest crop after cereals, rapeseed and potatoes. The EU is the biggest beet sugar producer in the world. Before the Sugar Reform in 2006, almost every EU Member State (MS) had sugar beet producers. During this reform, several MSs sold their sugar quotas and sugar beet growing in those MSs came to an end.

On 30 September 2017, the EU quota system came to an end. The competitive sugar beet growers and sugar beet factories in the EU have anticipated on that event and already increased their sugar beet area in the spring of 2017 to 1.7 million ha. The EU will probably become a net sugar exporting block again and sugar beet and sugar prices are expected to fluctuate and to decrease. This market effect could be affected negatively due to the voluntary coupled support (VCS) for sugar beet growing, which was adopted by eleven MSs of the Union: Poland, Czech Republic, Italy, Spain, Romania, Croatia, Slovakia, Hungary, Finland, Lithuania (since 2017) and Greece. The newest CAP Reform of 2013 made it possible to support sugar beet growing through coupled payments starting in 2015 in the case that the sugar sector faces difficulties (EU Regulation 1307-2013). The maximum area in the EU as a whole for VCS support of sugar beet growing is 497,200 ha (EU, 2014).

\section{Research questions}

In this report, two main questions are raised:

1. How strong is the effect of VCS in sugar beet growing on the production and prices of sugar beets in the EU? Does it affect the relative competitive power of sugar beet growing MSs with and without VCS and the level playing field in the EU sugar sector?

2. Is it legitimate to adopt and implement VCS in sugar beet growing, at least in the way that it is currently carried out?

\section{Methodology}

These research questions were answered through 1) data collection on e.g. sugar beet areas and Standard Output (SO; this is the value for the sales of a crop, standardised over time for a region and is used in this study as a proxy for gross margins, as those data are not available) of sugar beet and alternative crops in the VCS-MSs and in other MSs; these data provide insight into the competitive power of sugar beet in different MSs; 2) model calculations on sugar beet production and prices using an equilibrium displacement model (EDM), which allows for assessing the impact of VCS on sugar beet production at MS level and how this impacts the sugar market (price, demand).

Big changes in sugar beet areas in the last decade

Sugar beet areas in many MSs have significantly changed since 2005. Between 2005 and 2007, a major sugar reform took place in the EU and, as a consequence, the total sugar beet area in the EU dropped from 2.2 to 1.8 million ha. This decrease continued until 2015, so that in that year only 1.3 million ha sugar beet remained, a decrease of 40\% compared to 2005. However, in 2016 the sugar beet area in the EU increased to 1.4 million ha, in anticipation of the abolishment of the sugar quota system in 2017, when 1.7 million ha of sugar beet were registered.

Different, sometimes high, levels of Voluntary Coupled Support in ten MSs

In 2015 , the ten VCS-MSs were expected to receive VCS amounts varying between $€ 90$ and $€ 610$ per ha or $€ 2-20$ per tonne of sugar beet. In reality, the amounts were even higher, because the ten VCSMSs (excluding Lithuania) harvested 390,000 ha area of sugar beet in total compared with a potential area of 497,000 ha; the MSs involved decided to use the maximum VCS amounts and increased the VCS payment per ha of sugar beet. From 2016 onwards, the harvested area will be closer to the potential area. The VCS implies an effective price subsidy varying from about 5 to $50 \%$ of the price paid by the sugar company. VCS changes the amounts of direct payments per ha of sugar beet. Depending on the area of sugar beet per region and the VCS level in the MSs, VCS amounts are not 
evenly distributed over the 60 major sugar beet growing regions in the VCS-MS. Four regions received more than 10 million euro in 2015, three in Poland and one in Spain. On the other hand, 28 regions received less than 1 million euro, among which Finland, Italy and Greece.

On average, the following observations were made:

- In the VCS-MSs, there is a relatively small sugar beet area per grower compared to the other sugar beet growing MSs

- They have relatively low sugar beet yields per ha.

Conclusion: Sugar beet growing is less profitable in the VCS-MSs and they benefit less from economies of scale compared to the rest of the EU.

Defending VCS, one could say that 'only' 4.1 billion (or 9\%) of the total direct payments in 2015 (45.4 billion euro) were paid as coupled support; for sugar beet this was only $0.4 \%$ of the annual amount. A share of $0.4 \%$ seems a relatively small figure, but an average VCS-amount of 354 euro/ha is relatively high compared to the direct payments per ha.

Sugar beet as a competitive crop throughout the EU

To assess the competitiveness of sugar beet with alternative crops, i.e., cereals and rapeseed, Standard Output data were compared. Focusing on the individual MSs, the Standard Output (SO) of sugar beets was always at least 700 euro/ha higher than that of cereals and at least 600 euro/ha higher than that of rapeseed, not taking into account VCS. Including VCS, the differences with both alternative crops were mostly higher than 1,000 euro/ha, except for Finland. On average, the difference between SO sugar beet and SO cereals in the VCS-MSs (1,175 euro/ha) is already higher without VCS payment than in five non-VCS-MSs included in this study (Belgium, France, Germany, the Netherlands and the United Kingdom: 1,106 euro/ha). Including VCS, this difference with both cereals and rapeseed is higher for the VCS-MSs than for the non-VCS-MSs. Thus, sugar beet is a competitive crop in all VCS-MSs compared to cereals and rapeseed, even without a VCS premium.

A deeper analysis of the data of the different VCS-MSs showed that there is apparently no relationship between sugar beet yields and the amount of VCS per ha. On average, the sugar beet prices were not significantly lower in the VCS-MSs than in the non-VCS-MSs (34.2 and 36.0 euro/tonne). For the VCS group as a total, the average income was significantly lower (14,000 euro per farmer per year) than in the other five MSs.

VCS leads to a higher sugar beet production and a lower sugar beet price

The impact of VCS on EU sugar beet production has been simulated using an Equilibrium Displacement Model (EDM) based on a number of assumptions and expert estimates. On average, as a result of the VCS, EU sugar beet production has been estimated to increase by about $1.3 \%$, which generated an induced price decline of about 4.5\%. Sugar beet growers in MSs that apply VCS in general benefit, because they receive a higher payment per ha of sugar beet than without VCS. Sugar beet growers in MSs that do not apply the VCS instrument are negatively affected, because of the induced price decline. Aggregating all effects there is a net gain at EU-28 level for the sugar beet growers, which amounts to about 83 million euro. MSs that apply VCS gain 215.9 million euro, whereas the MSs not applying VCS face a loss of 132.7 million euro. The simulated results provide an insight into the order of magnitude of the impacts of VCS on the EU sugar sector and their distribution over MSs, conditional on a number of assumptions that had to be made to be able to make the quantitative calculations.

Doubts about the legitimacy of the voluntary coupled support as it is currently applied Voluntary coupled support is an instrument which generates different impacts on EU policy objectives. On the one hand it can contribute to sustain production in regions where production is in decline or facing difficulties. As such, it has a social function and may also contribute to the stewardship function of agriculture; sugar beet helps to broaden the crop rotation and, as a consequence, to maintain or improve the yields of the other crops, which is also a part of the greening (diversification) policy of the EU, included in the CAP. On the other hand, voluntary coupled support, when unevenly applied, may hamper the idea of the single market and negatively affect a level playing field. The wording in the legislation suggests a targeted rather than a generic application of voluntary coupled support to 
sectors. However, the application of voluntary coupled support to sugar beets, as well as to other sectors has generally been applied in a country-wide way, including all producers. This has been facilitated by the area ceilings granted to MSs, which are so generous that they allow for the inclusion of a MS's whole sugar beet production. As a result, MSs are not enforced to prioritise between producers who are more and less in need of this type of support. As such an evaluation of the implementation of VCS as it has been applied is needed to assess whether the instrument has been properly used so far and when this is questioned to come with proposals how to better apply the instrument. 


\section{Introduction}

\section{$1.1 \quad$ Context}

In the EU, sugar beet is a major arable crop (1.3 million ha in 2015), the largest crop after cereals, rapeseed and potatoes. The EU is the biggest beet sugar producer in the world. Before the Sugar Reform in 2006, almost every EU Member State (MS) had sugar beet producers. During this reform, several MSs sold their sugar quotas and sugar beet growing in those MSs came to an end.

On 30 September 2017, the EU quota system came to an end. The competitive sugar beet growers and sugar beet factories in the EU have anticipated on that event and already increased their sugar beet area in the spring of 2017 to 1.7 million ha. The EU will probably become a net sugar exporting block again and sugar beet and sugar prices are expected to fluctuate and to decrease. This market effect could be affected negatively due to the voluntary coupled support (VCS) for sugar beet growing, which was adopted by eleven member states (MSs) of the Union: Poland, Czech Republic, Italy, Spain, Romania, Croatia, Slovakia, Hungary, Finland, Lithuania and Greece. ${ }^{1}$ The newest CAP Reform of 2013 made it possible to support sugar beet growing through coupled payments starting in 2015 in the case that the sugar sector faces difficulties (EU Regulation 1307-2013). According to this regulation, MSs are allowed to use part of their national envelope for direct payments for coupled support in certain clearly-defined cases. The resources that may be used for any coupled support should be limited to specific sectors or regions in a MS where specific types of farming or agricultural sectors are particularly important for economic, environmental and/or social reasons. The 'particular situations' refer to sectors that 'undergo certain difficulties' (cf. Article 52(3)) and to the extent necessary to 'create an incentive to maintain current levels of production in the sectors or regions concerned' (cf. Article 52(5)).

Coupled support shall take the form of an annual payment and shall be granted within defined quantitative limits and be based on fixed areas and yields (cf. Article 52 (6)). MSs are allowed to employ up to $8 \%$ of their national ceilings for such coupled support, or $13 \%$ where the level of coupled support exceeds $5 \%$ in at least one year during the period 2010-2014 or where farmers received a single area payment prior to 31 December 2014. Further, to maintain the protein-based autonomy of the breeding sector, MSs that decide to use at least $2 \%$ of their national ceilings to support the production of protein crops are allowed to increase those percentages by upwards of two percentage points. In some cases, where it can be demonstrated that a certain sector or region is in particular need and upon approval by the Commission, MSs can use more than $13 \%$ of their national ceiling.

MSs define both the types of agricultural output, sectors and regions to be covered by VCS, and the level of support. Based on MS notifications (August 2015), five sectors gather more than $84 \%$ of the VCS budget: beef \& veal, milk \& milk products, sheep \& goats, protein crops, and fruit \& vegetable. VCS is implemented by at least 15 MSs for each of these sectors (Table 1.1). Three sectors, notably beef \& veal, milk \& milk products and sheep \& goats, comprise nearly $75 \%$ of the VCS budget. As a proportion of the value of production (evaluated at producer prices), sheep \& goats, rice, beef \& veal, and sugar beets benefit most from a relatively high degree of support. The maximum area for VCS support of sugar beet growing is 497,200 ha (EU, 2015).

\footnotetext{
1 Lithuania also adopted VCS for sugar beet in 2017, which is not fully included in the analysis in this report.
} 
Table 1.1 Amounts allocated to VCS by sector in 2015 (million euros)

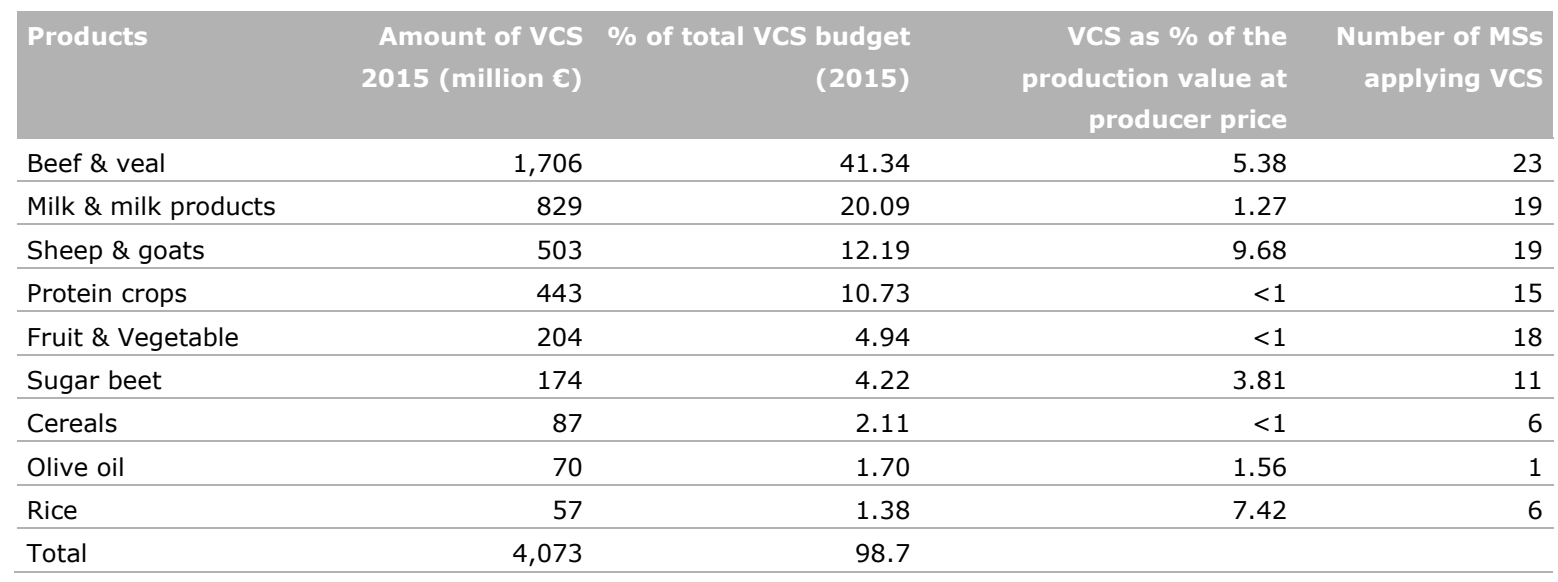

Source: DG AGRI, 2016 (sectors with a VCS share <1\% of total VCS are left out); the number of MSs applying VCS in sugar beet growing has increased from 10 to 11 in 2017.

The combined effects of the quota abolition and the VCS will lead to changes in competitive power of the sugar (beet) sectors within and between different MSs. Lower sugar beet margins will decrease the competitive power of sugar beet compared to other crops. If this situation becomes more or less structural, the supply of sugar beets to certain sugar plants will decrease, weaken their economic stability through higher relative costs of production. VCS can soften this effect, but is not generally and uniformly applied throughout the EU, changing the competitive relations within the EU. Among the ten so-called 'VCS-states' or 'VCS-MSs', the support per ha ranged from 90 euro in Finland to 610 euro in Romania (EU, 2016). As a consequence of the differences in support between these ten MSs and the other MSs and also within the group of ten MSs, the competitive power of MSs will change. Moreover, the price reducing effect of the quota abolishment will increase even more through stimulating sugar beet growing by the VCS-support (Smit and De Bont, 2011). The VCS support could soften this price-reducing effect in the VCS-MSs. It is unclear how the implemented VCS support affected the sugar beet sector including the sugar industry in VCS-MSs and in MSs without VCS support.

\subsection{Aim of the research}

The study is commissioned by the Wirtschaftliche Vereinigung Zucker e.V. (Association for Sugar Sector Business, WVZ) in Bonn. WVZ wants to stimulate a good, fact-based discussion in the EU about the effects of the VCS support and whether such a regulation is legitimate. They state that if the regulation itself or its practical application has negative effects on the growers without VCS support or negative, unwanted side-effects, then the EU should adapt the regulation. The EU motto 'a level playing field' should be restored as much as possible and allow only for small exceptions. These exceptions should then be defendable on the basis of production cost calculations.

This study should independently contribute to a rational discussion, supply data and facts and analyse the VCS-support regulation in depth.

\subsection{Research questions}

The key questions of WVZ were:

1. Which data and facts are available about the sugar beet areas in the EU and the VCS-support levels in the ten VCS-MSs?

2. How high are the production costs of sugar beet growing in these countries and in the other sugar beet growing MSs? 
3. Which effects does the VCS support for sugar beet growing have on the sugar beet areas in the ten VCS-MSs and in the other sugar beet growing MSs without VCS support, and on the EU sugar market?

4. To what extent is national or regional VCS support legitimate?

Question 4 was broken down in the following sub-questions:

a. Are coupled payments consistent with the basic principles of a common EU sugar market?

b. During the 2006 Reform, subsidies were paid for leaving the beet and sugar production. Does the coupled support not counteract those measures?

c. The CAP regulation requires that payments are coupled to strict conditions (no increase of sugar beet area; payments should only stabilise the cultivation). Were these conditions met?

d. Why is it important to restrict the VCS payments to carefully described critical cases?

e. Are there reasons to defend a different approach of payments with sugar beets compared to other cultures or products? E.g.:

i. The question which effects hindering of competition in the internal market have on the competitive power of exports of individual MSs/producers:

ii. The question whether MSs without VCS payments experience negative effects, since sugar beets have to compete with other crops.

\subsection{Scope}

In this report, the following scope was applied:

1. Data collection and scenario calculations were focused on sugar beet and sugar. Other crops were only taken into account in estimations on the competitive power of sugar beet compared to other relevant crops in different member states and regions;

2. Data collection and scenario calculations were only calculated for regions with current sugar beet cultivation, not for regions with potential cultivation;

3. Data collection from FADN (Farm Accountancy Data Network from the EU) was applied on the latest release of this dataset, being 2013;

4. Data were only collected form statistical sources, not from field work in different MSs with or without VCS;

5. Indirect effects of VCS on e.g. regional economy were only estimated in a qualitative way, not quantitatively.

\subsection{Contents of the report}

The structure of this report is as follows. Chapter 2 describes the methodologies used in this study. The current situation in (mainly) the ten VCS-MSs is described in Chapter 3 (facts and figures), followed by an analysis of the competitiveness of sugar beet compared to other, alternative crops in different MSs and regions (Chapter 4). The impact of the VCS-support for sugar beet on the production of sugar beet and the market situation of sugar in the EU is analysed with an equilibrium displacement model, which is described in Chapter 5. Chapter 6 describes legitimacy aspects of the VCS as applied in the VCS-MSs. Chapter 7 contains the conclusions and recommendations of this study. Finally, a reference list and a number of appendices with detailed information are presented. 


\section{Methodology}

\subsection{Assessing the competitiveness of sugar beet production in the VCS-MSs}

\subsubsection{Competitiveness}

Competitiveness is a relative as well as an absolute concept which focuses in this case on profitability of crops. The relative profitability of crops can be assessed with indicators like gross margins. Higher gross margins indicate a higher profitability and thus a higher competitiveness in the cropping plan of farmers. There is also an absolute profitability. A crop is only selected by a farmer when a certain trigger value of profitability is expected. The crop needs to add substantially to the income of the farmer and its returns must at least cover the direct and operational costs.

In assessing competitiveness, the production curve has to be taken into account (Figure 2.1). The production curve (in red) gives the potential combinations of (in this case) winter wheat and sugar beet, i.e. the hectares of both crops within the available area at the farm. Assume point $A$ as a starting point. When the area of sugar beet is increased to point $B$, then the farmer has to take the opportunity costs into account. The increased benefits from the additional sugar beet area should compensate for the loss of benefits from winter wheat due to a decreased area of winter wheat. The competitiveness between both crops, expressed as the ratio between increased benefits through an increased sugar beet area and the loss through a decreased winter wheat area, depends on the relative prices of both crops (orange lines in Figure 2.1). In point $A$, the relative price ratio for sugar beet compared to winter wheat (orange line 1 ) is lower than in point $B$ (where orange line 2 has the same angle as the production curve). Thus, competitiveness depends on what happens at the margin and marginal profitability can differ from the average profitability.

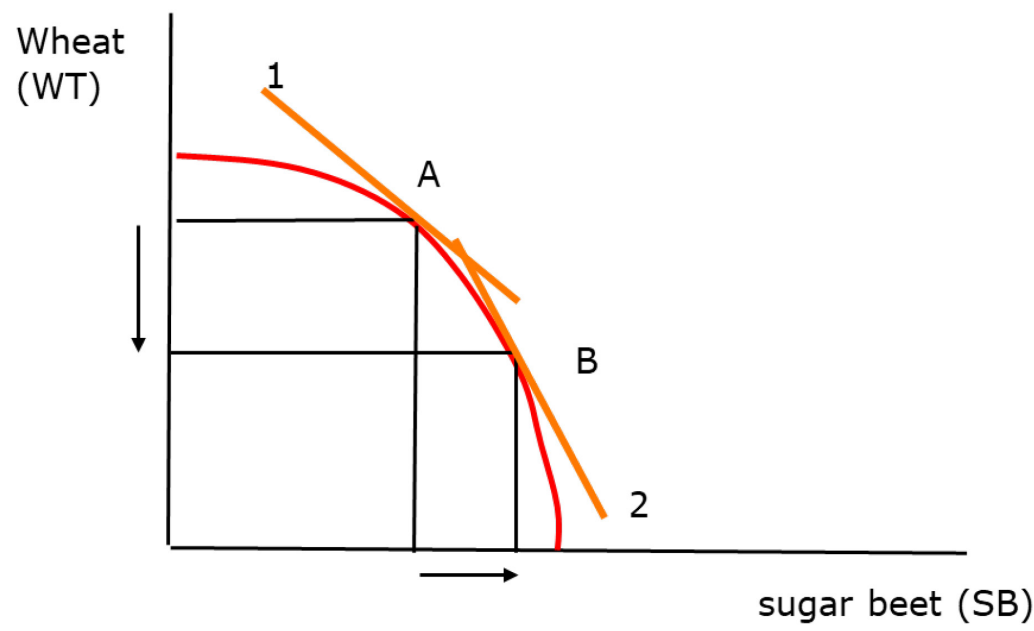

Figure 2.1 Competiveness of sugar beet versus winter wheat at different points of the production curve (derived from general economic theory)

The aggregate response of farmers to changes in the competitiveness of sugar beet compared to alternative crops in a region leads to a supply effect or changes in sugar beet areas in that region. The competitiveness can change through price changes, e.g. as a result of the abolishment of sugar quota or the application of coupled support. From the concept of competitiveness as explained in Figure 2.1, 
it follows that there is a difference between different farms in the way they respond to the change in competitiveness:

- Farms with high yields and no room to expand will react only little;

- Farms with lower yields and room to expand will react stronger.

In the assessment of changes in competitiveness, not only the absolute level of different crop margins is relevant, but also the differences in margin between sugar beet and relevant alternative crops. Farmers will only be interested in a change in cropping plan when the replacement of e.g. winter wheat through sugar beet is expected to give a multi-year and significant increase of returns. Changes in cropping plan can require investments and lead to extra risks. In general, sugar beet growing requires more knowledge than winter wheat growing and correlates with higher risks e.g. through frost damage or harvesting problems in wet autumns. The perception of individual farmers of those aspects will influence his responsiveness to changes in competitiveness of sugar beet compared to other crops.

In the next section, it is explained how the competiveness of sugar beet compared to other crops was assessed in this study. That assessment is based on average figures. However, as explained above, an assessment with average figures is in fact a simplification. This was solved through the modelling study as described in Chapter 5.

\subsubsection{Standard Outputs as a basis for competitiveness analysis}

The best indicator to compare the competitiveness of crops is the gross margin, defined as returns minus direct costs. However, data on sugar beet margins in the different MSs are not (yet) available from open databases like FADN or Eurostat. As an alternative, Standard Output data (SO) can be used as a second best option:

$\mathrm{SO}=$ total returns of a crop $=$ yield $*$ price

Thus, variable costs are not included in this comparison. However, SOs vary more between farmers/regions/MSs (Hanse et al., 2010). SOs for different crops and livestock are made available in Eurostat per MS and specifically for many regions. ${ }^{2}$ However, the latest set is the one of 2010, which gives average values over 2008 - 2012. The assessment of SOs is carried out throughout the EU following a strict protocol with five-year averages, which assures the user of a certain reliability and credibility of the SO-dataset.

As an example, a comparison between sugar beet, winter wheat and rapeseed in Niedersachsen and Schleswig-Holstein is shown (Table 2.1). The margin of sugar beet was lower in Niedersachsen than in Schleswig-Holstein. However, the margins of the alternative crops were even lower. In Niedersachsen, the differences in margin between sugar beet on one side and winter wheat and rapeseed on the other were 570 and 970 euro/ha, respectively. For Schleswig-Holstein, these differences were 480 and 880 euro/ha, respectively. The differences were larger in Niedersachsen than in Schleswig-Holstein, indicating that sugar beet has a stronger competitiveness compared to winter wheat and rapeseed in Niedersachsen than in Schleswig-Holstein, although the crop margin is lower. A comparison of SOs gives differences of 810 and 1,010 euro/ha in Niedersachsen and 640 and 840 euro/ha in SchleswigHolstein, leading to the same conclusions on competitiveness. In conclusion, the competitiveness of sugar beet compared to other crops was in Niedersachsen (slightly) better than in Schleswig-Holstein, despite its lower margin. It does not matter whether total output or margin is evaluated. The overall differences between crops are equal under the condition that the difference in variable costs of crops is equal between regions. For neighbouring regions, such an assumption seems quite reasonable. In this study comparisons of SOs between crops are mainly carried out within MSs or regions, making levels of direct costs between different MSs or regions less important.

2 http://ec.europa.eu/eurostat/web/agriculture/so-coefficients 
Table 2.1 Calculation and comparison of margins and SOs for sugar beet, winter wheat and rapeseed in two regions in Germany, based on data from 2010

\begin{tabular}{|c|c|c|c|c|c|c|c|}
\hline \multirow[t]{2}{*}{ Indicator } & \multirow[t]{2}{*}{ Unit } & \multicolumn{3}{|c|}{ Niedersachsen } & \multicolumn{3}{|c|}{ Schleswig-Holstein } \\
\hline & & Sugar beet & $\begin{array}{l}\text { Winter } \\
\text { wheat }\end{array}$ & Rapeseed & Sugar beet & $\begin{array}{l}\text { Winter } \\
\text { wheat }\end{array}$ & Rapeseed \\
\hline Price & euro/tonne & 35 & 160 & 400 & 35 & 160 & 400 \\
\hline Output & euro/ha & 2,450 & 1,280 & 1,440 & 2,520 & 1,440 & 1,680 \\
\hline Direct costs & euro/ha & 1,000 & 600 & 800 & 1,000 & 600 & 800 \\
\hline Margin & euro/ha & 1,450 & 880 & 640 & 1,520 & 1,040 & 880 \\
\hline \multicolumn{8}{|c|}{$\begin{array}{l}\text { Difference with } \\
\text { sugar beet }\end{array}$} \\
\hline
\end{tabular}

Source: Eurostat.

Based on the concept of competitiveness and the example for two German regions, competitiveness was evaluated on the basis of the difference in SO between the sugar beet production and the cultivation of cereals and rapeseed. This difference was calculated for the most important sugar beet production regions in the VCS-MSs and in some non-VCS-MSs. At maximum seven regions per MS were selected, the ones with the largest areas of sugar beet in that specific MS. This selection is shown in Map 3.1.

The following steps were taken:

1. SO data were collected for sugar beet for MSs and regions.

2. Cereals (common wheat, durum wheat and barley) and rapeseed were selected as most common alternative crops for sugar beet. Most arable farms already grow at least one of these crops. They relatively easily fit in in most cropping plans and do not require a lot of investments or special skills. ${ }^{3}$

As far as possible the same regions in the VCS-MSs were selected as shown in Map 3.1 and SOs for sugar beet and the alternative crops were compared, completed with some average data on differences in direct and operational costs. A limitation of the SO approach is that the SOs of wheat and rapeseed can be higher on sugar beet growing farms than elsewhere. As such the differences given in the analysis may be somewhat overestimated in regions with a relatively high diversity in soil characteristics, specifically in the ability to grow sugar beet. As for this study there was no access to individual farm FADN data (but only to farm group data) and FADN farm group data suffers from the similar limitations as the SO approach, the choice for this latter approach has been made for the farm level assessment.

\subsection{Model calculations with an equilibrium displacement model (EDM)}

The impact of the VCS payments in ten MSs, including the reform of the EU's sugar policy (abolition of the quota system), was estimated with a stylised equilibrium displacement model (EDM). The analysis in particular focused on the supply side and sugar beet production by the EU arable sector, whereas the processing and demand for quota and non-quota sugar were included in a more aggregated way.

\footnotetext{
3 Sugar beet and rapeseed compete in the cropping plan for rotational effects: the two crops are sensitive to the same nematode species. Therefore, the total area of both crops cannot exceed $25 \%$ of the cropping area. Potatoes were also considered as an alternative crop. However, in the VCS-MSs potatoes have a relatively low SO compared to MSs like Germany, France and the Netherlands, with high-yielding ware and seed potatoes. Potato growing demands special skills of the farmer and in many cases high investments in buildings and equipment for storage, sorting and packaging. Moreover, potato growing can be limited by the cropping plan.
} 
In the following of this section first EDMs are briefly introduced, and the mechanism of how VCS affects the supply (production) of sugar beets is explained. Subsequently, information is provided about the calibration of the EDM model and the data that have been used (including base year choice). Also the main uncertainties and limitations of the EDM-modelling approach are indicated.

\subsubsection{The EDM modelling approach}

To assess the VCS market impacts, a counterfactual needs to be generated. For this a model has been developed, which is subsequently used to run simulations of the market impacts with and without VCS being implemented. In order to analyse the impact of voluntary coupled support applicable to sugar beets, an equilibrium displacement modelling (EDM) approach has been used. EDM models have a prominent place in applied policy analysis (Wohlgenant, 2011). The class of EDM models contains models that are technically speaking a set of behavioural equations, including exogenous shifters, expressed in elasticity form. An advantage of such models is that they allow the researcher to focus on the important elasticities (e.g. the sugar beet own price supply elasticities) and the relative importance of supply (e.g. the voluntary coupled support price equivalent mark-ups). Moreover, the approach allows us to use elasticities from previous research in the analysis, without having to econometrically estimate all the equations applied in the economic analysis. As EDM models rely on a linear approximation approach, the researcher does not have to be concerned with the exact functional form of the behavioural equations (at least to the extent that simulated equilibrium changes are deemed to be small). In case of the VCSanalysis, this assumption is likely to hold. EDM models have been applied in a lot of policy analysis studies (e.g., Sumner and Wohlgenant 1985; Gardner 1987; Sumner 2005) and by the USDA (including an application to the US sugar beet sector; see box 2.1 EDM modelling in US agricultural policy analysis).

The challenge in modelling the EU sugar beet sector is that due to the quota regime that applied till October 2017, there has been limited information available about the supply curve. Because the empirical information available dates from the time that the sugar quota regime was still in place, an additional question was at which point at their supply curves MSs are producing.

In order to solve this issue, we constructed the year 2017 as a base year, where (at the harvest time of sugar beets) the quota no longer applies. As a consequence, all quota rents are nil at that moment and marginal costs will coincide with the observed national prices. So, the 2017 base year has been assumed to be a year at which all MSs are at their supply curves (i.e. supply is not constrained by quota restrictions). Because in 2017 the VCS already applies, it is assumed that the relevant incentive price for sugar beet growers is the price which at planting time they expected to prevail in the market at harvest time (2017 campaign) plus, when applicable, the voluntary coupled support applicable to sugar beets (evaluated at a per tonne of sugar beet equivalent).

\section{Box 2.1 EDM modelling in US agricultural policy analysis}

Within the USDA, development of the Equilibrium Displacement Mathematical Programming Model (EDMP) started in response to the passage of the FAIR-Reform Act of 1996. This 1996 Farm Act fundamentally changed the traditional economic incentives in commodity policies by decoupling most Government commodity payments from the levels of individual farmers' production of the commodities, by eliminating acreage reduction programmes, and by no longer limiting production eligible for support to a producer's historic production base. The effects of these changes in economic incentives were to render temporarily obsolete all econometric policy simulation tools estimated under the previous policy regime. The first published article using EDMP assessed the likely effects of the 1996 Farm Act on production, prices, net farm incomes, and farm asset values in the Great Plains. This analysis included the impacts of direct payments, accounting for their impacts on production (via the use of coupling factors). Subsequent applications of the EDMP framework evaluated the effects of market of a broader set of policy issues, including resistance to genetically modified grains and the implications of demand and supply elasticities for the distribution of rents in supply chain industries.

Source: Harrington and Dubman (2008) 
The impact analysis of the VCS on the supply of sugar beets could then be simulated by running a counterfactual scenario, where the VCS is set to nil for all MSs. The impact of VCS could be determined by comparing the simulated equilibrium with the 2017 base year situation.

For a graphical illustration see Figure 2.2, which represents the impact of VCS for a MS with a VCS arrangement (right panel) and without a VCS arrangement (left panel). Each MS is assumed to have linear (inverse) upward sloping supply curve for sugar beet production (see $S_{m c}$ curves in Figure 2.2). In the model, VCS is implemented as a subsidy to supply, which effectively lowers the production costs (represented by a downward shift of the supply curve). ${ }^{4}$ Assuming the price is initially equal to $\mathrm{P}^{\mathrm{s}}$, VCS will lead to an increase in sugar beet production in those MSs that apply VCS, with the supply increase being a function of the magnitude of the VCS per tonne of sugar beet produced.

In the model this is not the end stage yet, as the increase in supply will induce a price decline, which is necessary to create a new market equilibrium in which supply equals demand. This price decline is indicated in the figure by the shift of the price from Ps to P1. The magnitude of this price decline is determined by the responsiveness of the demand to an increase in EU sugar beet production. ${ }^{5}$ The price decline will affect all sugar beet growers in the EU independently whether they receive VCS (right panel) or not (left panel). As a consequence of this induced price decline, supply will adjust (MSs will 'walk down' on their supply curve) with the new production levels being Q1. As compared to the initial production levels (see Q0), the country without VCS support will face a net decline in production, whereas the MSs in which sugar beet producers receive VCS will still have an increase in sugar beet production.

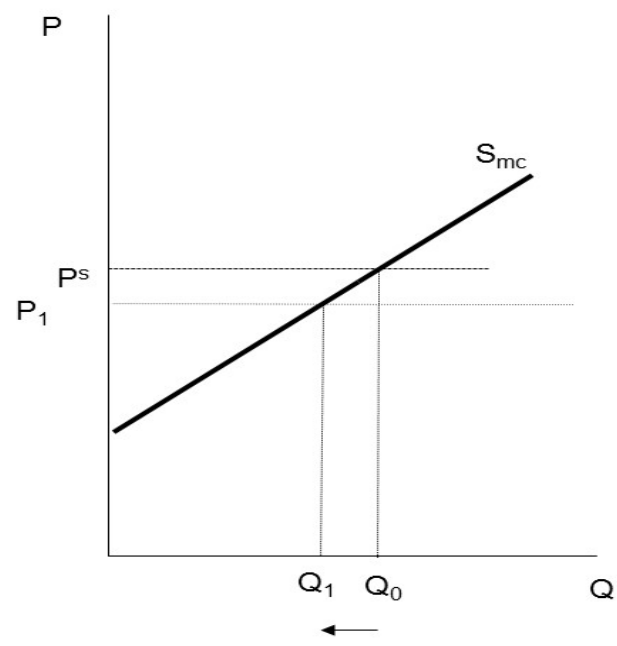

(a) MS without VCS

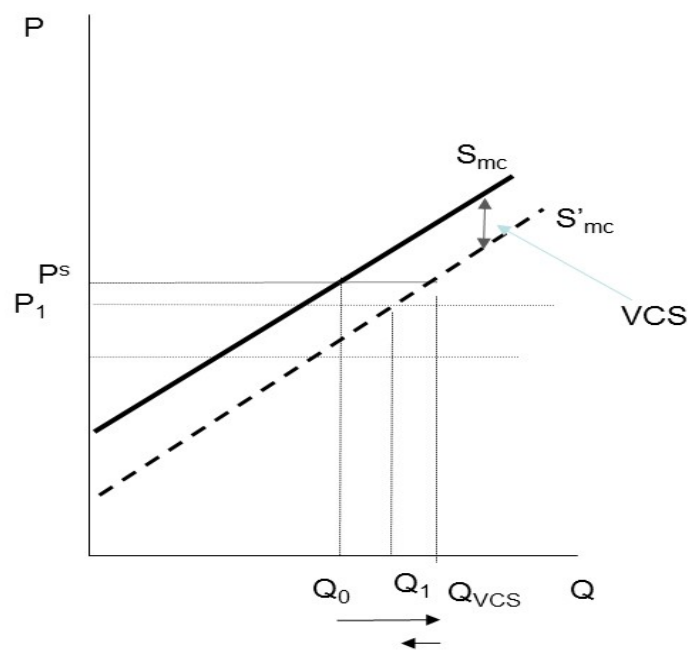

(b) MS with VCS

Figure 2.2 The potential impacts of VCS on MSs' sugar beet production

\subsubsection{Model calibration and base year data}

The EDM model has been calibrated to 2016/17 base year data (see Table 5.1 in Chapter 5 for a detailed overview). The prices have been estimated using available data. The price for industrial sugar beets (estimated at $€ 26 /$ tonne) has been used as the minimum price for sugar beets throughout the EU. The calculated prices include the impact of the VCS as this has been estimated to apply to the participating MSs (using 2015 information). The supply elasticities have been partly based on estimates and information that was available from the literature (Burrell et al., 2014, Nolte et al., 2012, Buysse et al., 2007, Gohin and Bureau, 2006) and partly estimated. Their values range from 0.1 (Belgium) to 0.9 (Italy), with the average value being 0.34 . The demand elasticity for sugar beet has been estimated to be -0.3 (also based on the literature; Burrell et al., 2014).

\footnotetext{
4 This approach is equivalent to the assumption that sugar beet growers get an effective price which is equal to the market price for sugar beets plus a mark-up due to the VCS (expressed in terms of a sugar beet price equivalent).

5 Although the aggregate EU demand for sugar beet is not presented in Figure 2.2, it is included in the model.
} 
It should be noted that calculations made using the EDM tool are subject to several uncertainties, which were mainly due to the lack of information with respect to the supply curves. As indicated above, based on the literature and expert information, supply elasticities were estimated which may not sufficiently reflect the situation under the new policy regime (quota abolition). Other sources of some uncertainty are related to the estimated sugar beet prices and VCS sugar beet price equivalent support rates, which among other things depend on estimated sugar beet yields per hectare and sugar content rates.

Moreover, the EDM modelling approach assumes no market imperfections along the supply chain (so potential impacts of contractual arrangements that affect supply have been neglected). The simulated outcomes that will presented later (see Chapter 5) are conditional on these assumptions. 


\section{Current situation}

\subsection{Large shifts in sugar beet areas in the EU since 2005}

According to CEFS (2016), 1,313,697 ha of sugar beet were harvested in the EU in 2015/2016.

Figure 3.1 shows the share of the ten largest sugar beet growing MSs in the total EU sugar beet area, with France, Germany and Poland covering more than half of the EU area. Each of them had a sugar beet area of more than 170,000 ha. In contrast, nine MSs had a sugar beet area smaller than 25,000 ha: Denmark, Finland, Sweden, Greece, Hungary, Slovakia, Croatia, Romania and Lithuania.

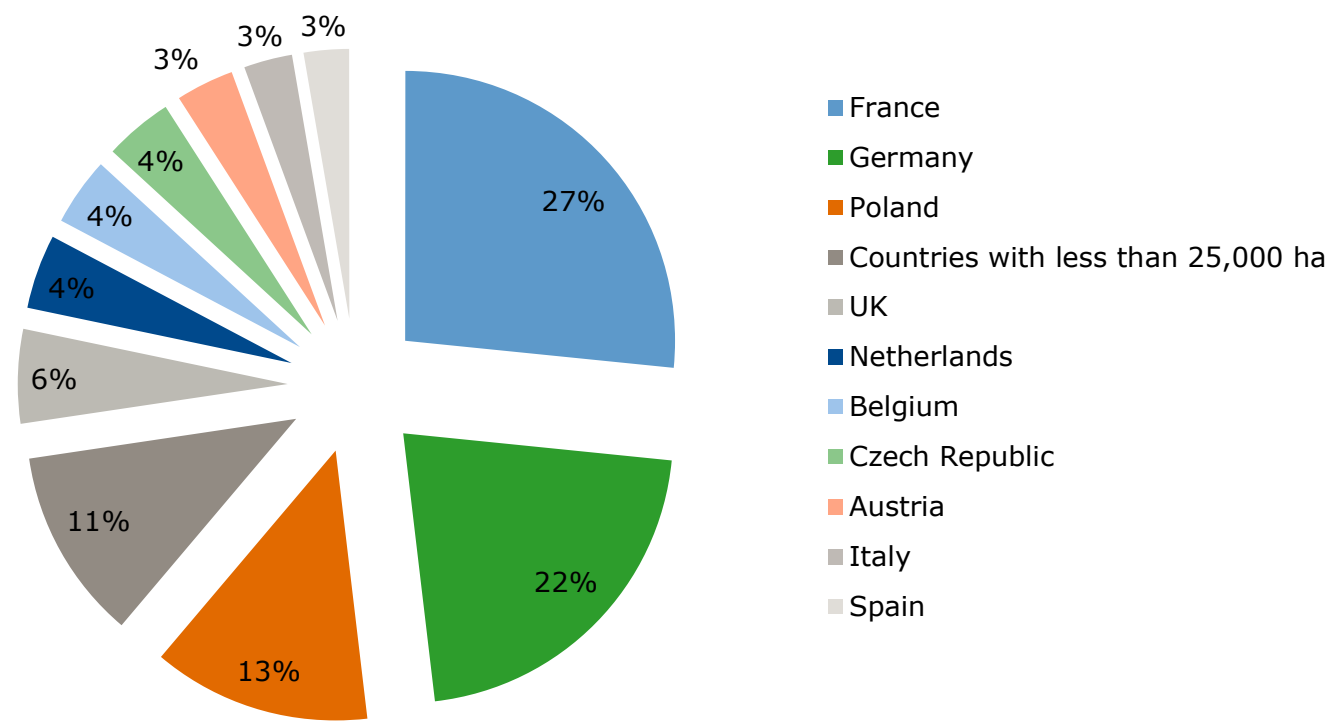

Figure 3.1 Share of sugar beet areas of MSs in the total sugar beet area in the EU

Sugar beet areas in many MSs have significantly changed since 2005 (Figure 3.2). More detailed information on the development in sugar beet areas in the EU since then is given in Appendix 1. Between 2005 and 2007, a major sugar reform took place in the EU and, as a consequence, the total sugar beet area in the EU dropped from 2.2 to 1.8 million ha. This decrease continued until 2015, the one-but-last year in the overview, so that in that year only 1.3 million ha of sugar beet remained, a decrease of $40 \%$ compared to 2005 . During the Reform, some countries, like Bulgaria, Slovenia and the Republic of Ireland, abandoned sugar beet growing totally or almost totally. However, in 2016 the sugar beet area in the EU increased to 1.4 million ha, possibly in anticipation of the abolishment of the sugar quota system in 2017, when 1.7 million ha of sugar beet were registered.

Focusing on the ten VCS-MSs, the total sugar beet area in these countries dropped between 2005 and 2007 from 839 to 581 thousand ha and then further to 410 thousand ha in 2016, a decrease between 2005 and 2016 of more than 50\%, which is a much stronger decrease than on average in the EU. As a consequence, the share of the ten VCS-MSs in the EU sugar beet area decreased from 37\% in 2005 to $29 \%$ in 2016 . In Greece, the sugar beet area nearly decreased to nil (5,000 ha). The relative importance of the VCS-MSs as a whole and individually is expressed in Figure 3.3. Poland was by far the most important sugar beet producer in this group of sugar beet growing countries with $14 \%$ of the total EU area of sugar beet. The Czech Republic, Spain, Italy and Romania made up for $11 \%$ in total, so that Poland, the Czech Republic, Spain and Italy together were responsible for a quarter of the EU sugar beet area in 2016. 


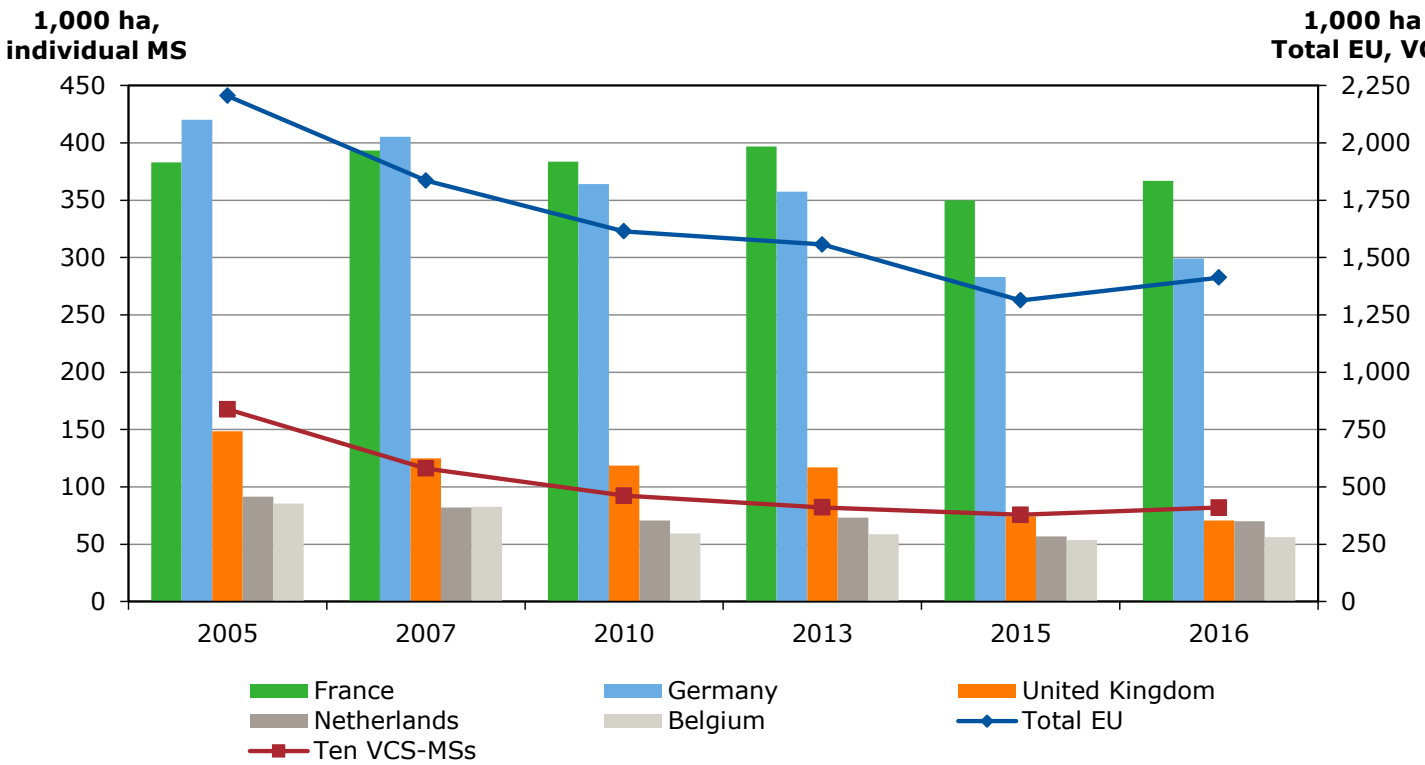

Figure 3.2 Total sugar beet areas in the EU, in the ten VCS-MSs and in the five largest sugar beet producing MSs outside the VCS-MSs in 2005, 2007, 2010, 2013, 2015 and 2016 Sources: Eurostat; DG Agri, 2016, adapted by Wageningen Economic Research.

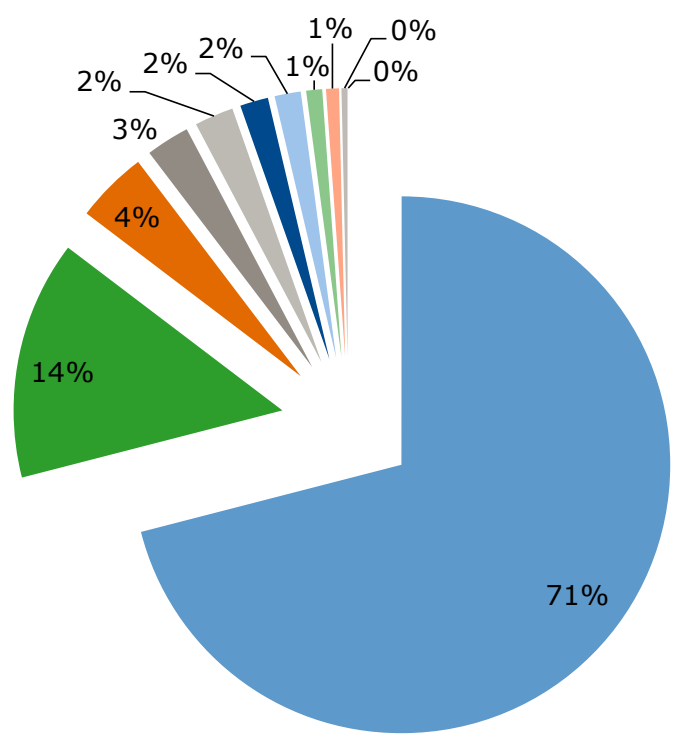

- Other MSs
" Poland
- Czech Republic
-Spain
Italy
- Romania
Slovakia
- Hungary
- Finland
- Greece
Croatia

Figure 3.3 Relative importance of the ten VCS-MSs in the EU sugar beet area in 2016 Source: DG Agri (2016), adapted by Wageningen Economic Research.

\subsection{Sixty relevant regions within the VCS-MSs}

Map 3.1 gives information on the 60 major sugar beet areas in these regions. More detailed information on the names of the regions and their statistical data on sugar beet areas is given in Appendix 6. Large areas of sugar beet can be found in Poland, Spain, Czech Republic, Slovakia, Italy and Romania. Map 3.2 shows the number of sugar beet growers in these 60 regions. Comparing Maps 3.1 and 3.2, average sugar beet area per grower differs across the 60 regions. Appendix 7 gives data on the distribution on sugar beet area per farm per category of sugar beet area in the 60 regions, both in absolute and in relative figures. 


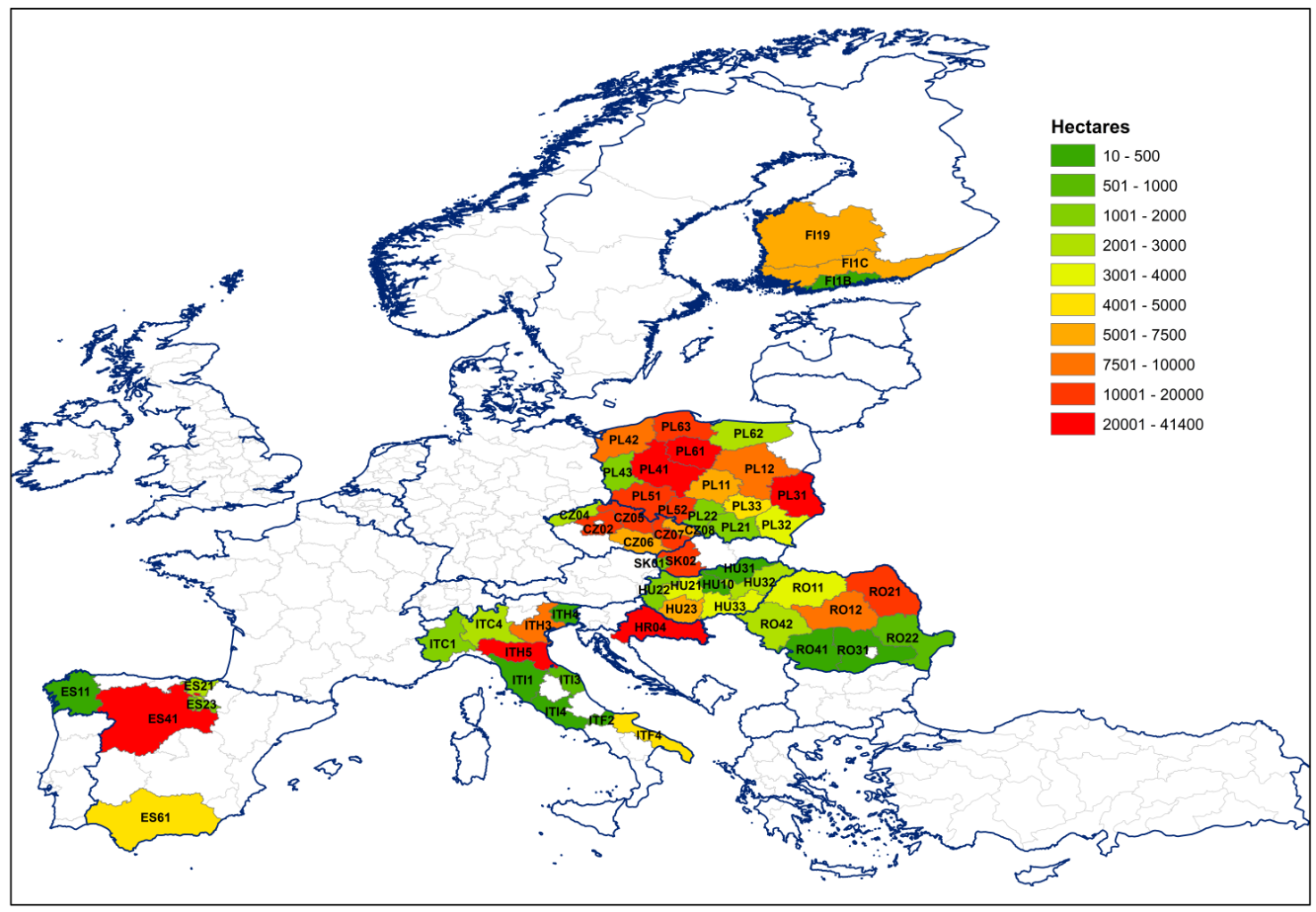

Map 3.1 Areas of sugar beet in 60 regions of the VCS-MSs in 2013 (total ha per region)

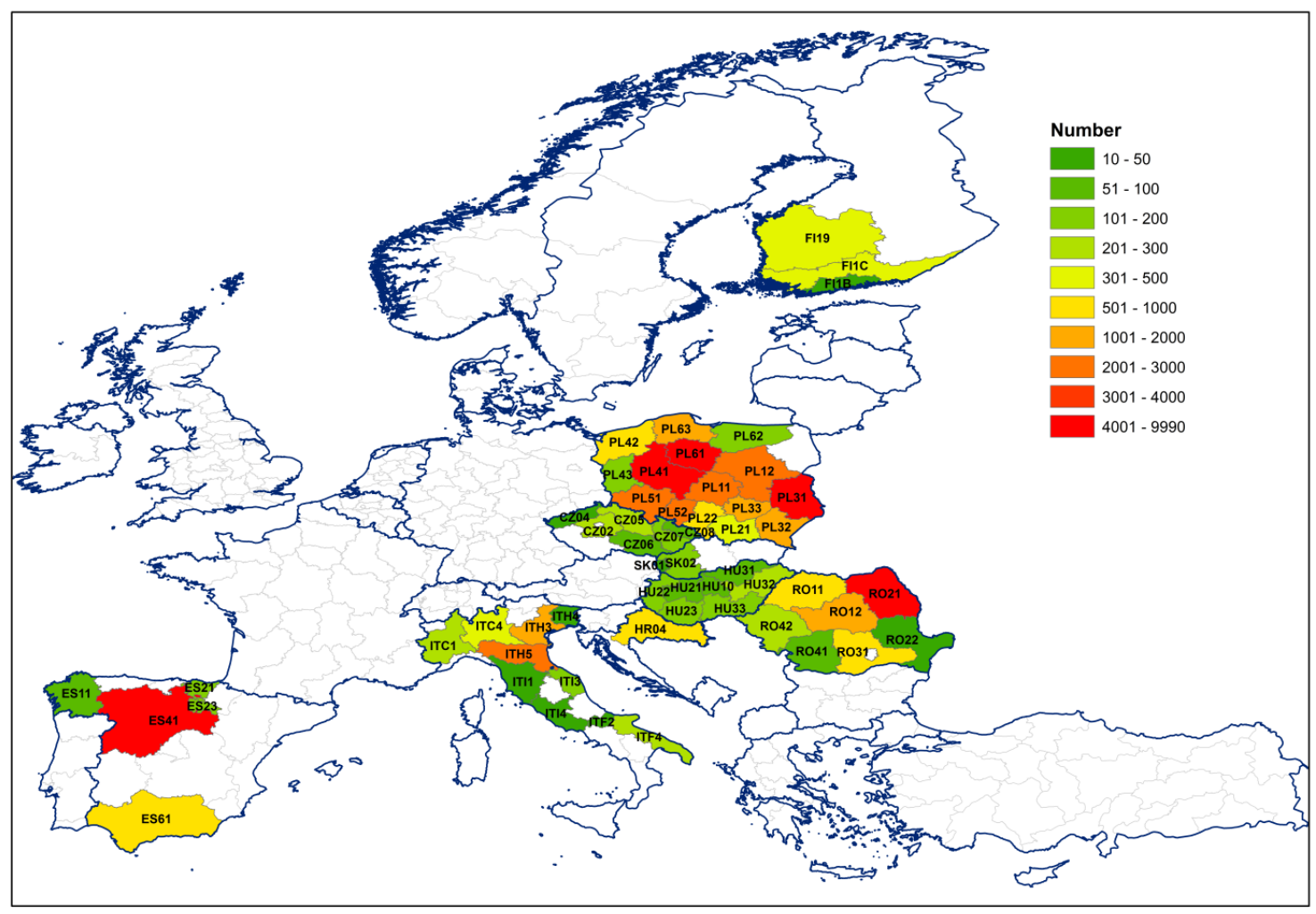

Map 3.2 Number of sugar beet growers in 60 regions of the VCS-MSs in 2013 (totals per region) 


\subsection{VCS-support levels very different in different MSs}

In 2015, the ten VCS-MSs were expected to receive VCS-amounts varying between $€ 90$ and $€ 610$ per ha or $€ 2-20$ per tonne of sugar beet (Figure 3.4; Appendix 2). However, the amounts presented were based on the maximum VCS-amount in a MS divided over the maximum sugar beet area for VCS-support in that MS. But in 2015, for all ten VCS-MSs, the harvested area of sugar beet was 390,000 ha and the potential area 497,000 ha (Appendix 1). The MSs involved decided to use the maximum VCS-amounts in their MS and raised the VCS-payment per ha of sugar beet (Table 3.1). In some MSs, this led to a significant increase, e.g. in Greece (from 374 to 523 euro/ha), Italy (from 276 to 442 euro/ha), in Poland (from 384 to 502 euro/ha) and, most remarkably, in Romania (from 600 to 784 euro/ha). Only in Slovakia, there was a small decrease of the VCS-payment per ha.

The measure to increase the VCS-amount per ha of sugar beet in case of under-utilisation of the maximum sugar beet, gives the impression that the VCS-amounts per ha were not only applied to compensate for a calculated loss. Political reasons seem to play a role as well. However, for a longterm analysis of the impact of VCS in sugar beet growing, the data on the support as planned in 2014 (i.e. 60-610 euro/ha) were used, expecting that in some years' time the maximum sugar beet area under the VCS-regulation would be reached due to the attractive support rates. Further analysis on the issue is given in chapter 4 .

The VCS implies an effective price subsidy varying from about 5-50\% of the sugar beet price paid by the sugar companies (Table 3.1, based on the national sugar beet prices in 2015/2016 and the regional sugar beet yields in the same year). In Finland and Croatia this subsidy was less than $10 \%$. In most other MSs the subsidy was $20 \%$ or more, with Italy and Romania on the top with about 30 and $45 \%$, respectively, or, in absolute figures 10-20 and 15-18 euro per tonne, respectively. The estimated total payment per ha, calculated as the direct payment per ha plus the VCS-payment (if applicable), was for Croatia and Finland at a comparable level as for Germany and France. Romania has a special position having a high level of support of more than 400 euro per hectare, which is higher than that of the other nine VCS-MSs. When the total payment is considered, also Greece has a remarkably high total ha-payment, mounting up to 750 euro/ha of sugar beets. ${ }^{6}$

The 60 most important sugar beet growing regions in the VCS-MSs with their VCS-payments per ha are shown in map 3.3. For further analysis in Chapters 3 and 4, we have focused on these regions. In 2015/2016, 24.5 million tonnes of sugar beet were processed in the VCS-MSs; 22.7 million of these or $93 \%$ grew in the 60 regions selected. In that year, the EU processed 110 million tons of sugar beet in total, of which $22 \%$ in the VCS-MSs. Large amounts of sugar beets were especially grown in Spain, Greece and different regions in Poland (map 3.4).

As shown in Figure 3.4, VCS changes the amounts of direct payments per ha of sugar beet. Depending on the area of sugar beet per region and the VCS-level in the MSs, VCS-amounts are shown not to be evenly distributed over the 60 regions (Map 3.5). Four regions received more than 10 million euro in 2015, three in Poland and one in Spain. On the other hand, 28 regions received less than 1 million euro, among which Finland, Italy and Greece.

Appendix 1 shows besides sugar beet areas per MS in different years the applicable quantitative limit for the area of sugar beet to be supported with VCS. The maximum area has not been fully used in all VCS-MSs except for Slovakia, where the beet area was 2,000 ha higher than the VCS area. For all ten VCS-MSs, the harvested area of sugar beet in 2015 was 390,000 ha and the potential area 497,000 ha. However, in 2016, the sugar beet area in these MSs was 405,000 ha excluding Croatia, of which no data were available for 2016. Assuming an area of 16,000 ha in Croatia for 2016, i.e. the same area as in 2015, the total sugar beet area in 2016 would be 421,000 ha, still leaving 76,000 ha of 'white spots'. These white spots were relatively large in Greece (8,000 ha out of 13,400 ha) and

\footnotetext{
6 The total payments per ha are given for a complete overview of the payments. However, the focus in this report is on VCS payments, which have a different nature and, as a consequence, different effects than (uncoupled) direct payments. Therefore, VCS and direct payments are only partly comparable.
} 
Hungary (7,000 ha out of 20,200 ha) and in absolute terms also in Italy (29,000 ha out of 62,300 ha). The area of white spots has decreased between 2015 and 2016.

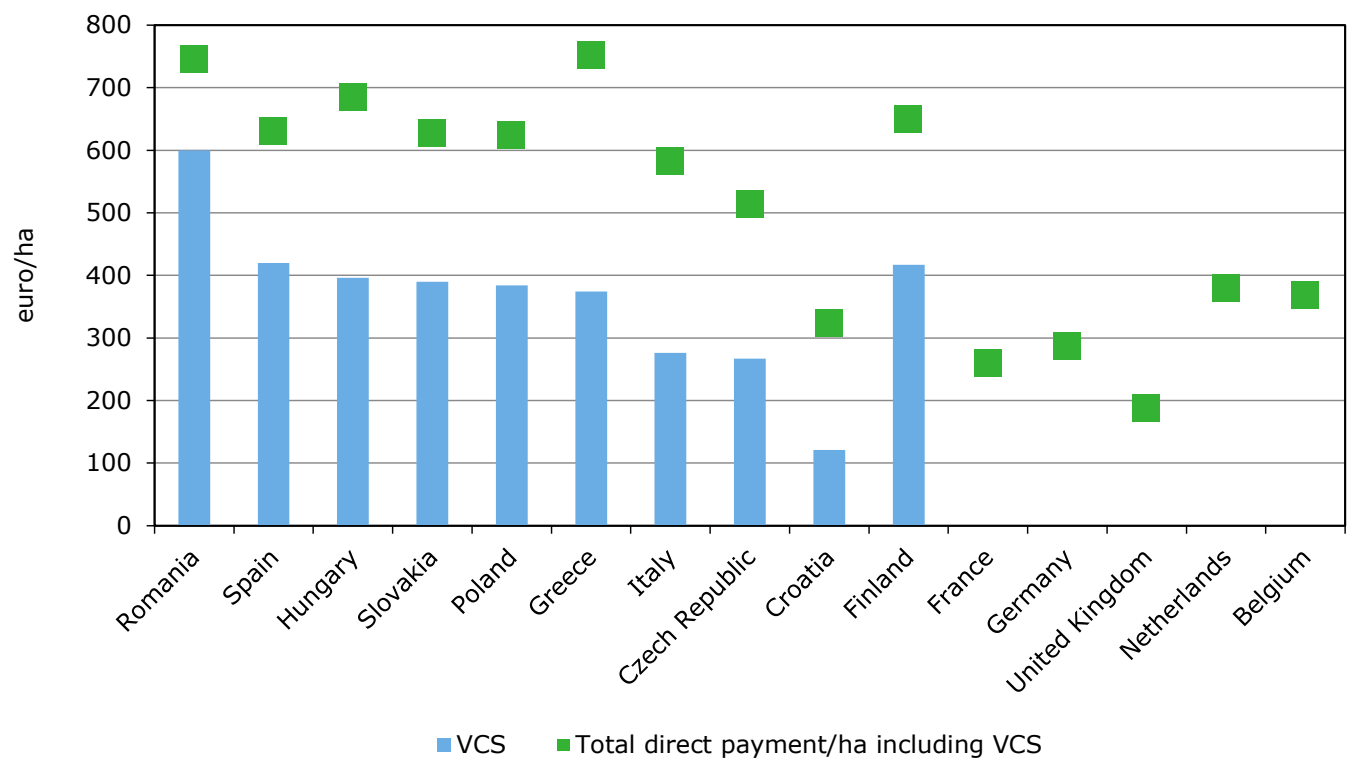

Figure 3.4 VCS payments (in 2015) and average total direct payments including VCS-support (in 2013) per ha of sugar beets in the VCS-MSs and the five largest sugar beet growing MSs without VCS a) a) For Finland, the VCS amount includes an additional coupled premium for sugar beet growing of 350 euro/ha.

Source: EP (2013) and EC (2015), adapted by Wageningen Economic Research.

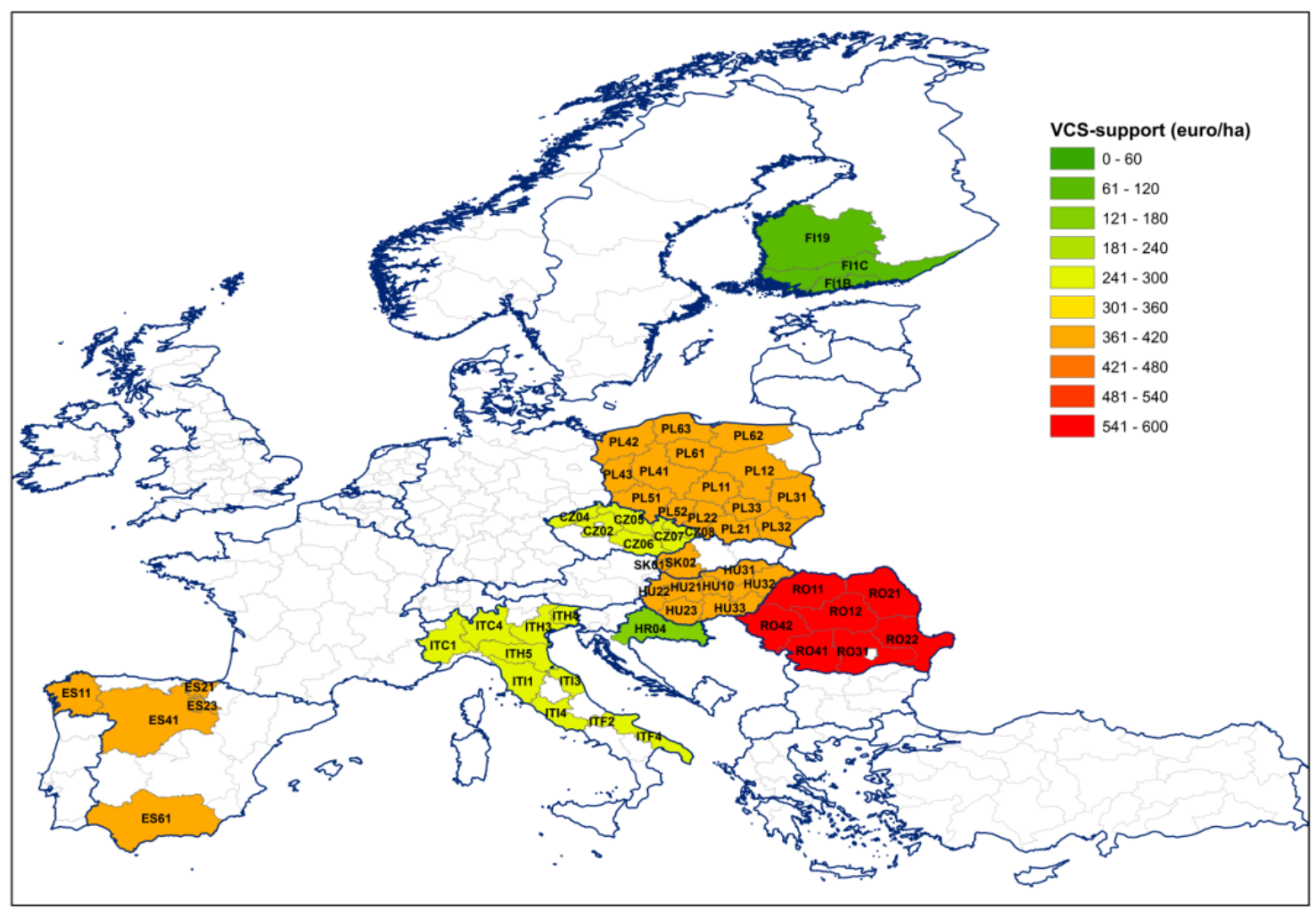

Map 3.3 VCS support per ha in the sixty most important sugar beet growing regions of the ten VCS-MSs in 2015 
Table 3.1 Maximum VCS-amounts per MS in million euro and average share of VCS support per tonne of sugar beet in 2015/2016. The list of MSs is shown from lower to higher total VCS payments for sugar beet available per MSs

\begin{tabular}{|c|c|c|c|c|c|c|c|}
\hline MS & $\begin{array}{r}\text { National VCS- } \\
\text { amount } \\
\text { (million euro) }\end{array}$ & $\begin{array}{r}\text { Sugar beet } \\
\text { price paid to } \\
\text { growers } \\
\text { (euro/tonne) } \\
\text { a) }\end{array}$ & $\begin{array}{r}\text { VCS } \\
\text { 'planned' } \\
\text { (euro/ha) } \\
\text { b) }\end{array}$ & $\begin{array}{r}\text { VCS 'real' } \\
\text { (euro/ha) } \\
\text { c) }\end{array}$ & $\begin{array}{r}\text { Average } \\
\text { sugar beet } \\
\text { yield } \\
\text { (tonne/ha) } \\
\text { d) }\end{array}$ & $\begin{array}{r}\text { VCS } \\
\text { (euro/tonne) } \\
\text { e) }\end{array}$ & $\begin{array}{r}\text { Share of } \\
\text { VCS- } \\
\text { support } \\
(\%) f)\end{array}$ \\
\hline Finland g) & 1 & 31.1 & 67 & 81 & 29.4 & $1.6-1.9$ & $5-6$ \\
\hline Croatia & 3 & 27.8 & 121 & 201 & 47.6 & 2.3 & 8 \\
\hline Greece & 5 & 26.3 & 374 & 523 & 37.2 & $5.8-6.7$ & $22-25$ \\
\hline Lithuania & & & & & 49.7 & & \\
\hline Hungary & 8 & 36.1 & 396 & 522 & 47.2 & $6.5-8.0$ & $19-22$ \\
\hline Slovakia & 8 & 32.6 & 390 & 370 & 50.0 & $6.1-7.0$ & $18-22$ \\
\hline Czech Republic & 17 & 31.2 & 267 & 289 & 55.5 & $4.3-4.7$ & $14-15$ \\
\hline Spain & 17 & 35.0 & 420 & 475 & 96.9 & $4.6-6.0$ & $13-17$ \\
\hline Italy & 17 & 44.2 & 276 & 442 & 48.7 & $10.5-19.7$ & $24-37$ \\
\hline Romania & 18 & 36.0 & 600 & 784 & 37.5 & $15.3-17.6$ & $42-49$ \\
\hline Poland & 81 & 28.6 & 384 & 502 & 48.1 & $6.1-8.3$ & $21-26$ \\
\hline
\end{tabular}

a) Sugar beet price paid to the growers, not including VCS-premium;

b) VCS amounts per ha as originally planned in the VCS-scheme (Appendix 2);

c) VCS amounts per ha as really paid after correction of sugar beet areas under the maximum areas (DG Agri, 2017);

d) Sugar beet yields were calculated from data on sugar yields per ha and sugar content; for Romania, a sugar content of $16 \%$ was assumed because of missing data;

e) Calculated as the 'planned' VCS support per ha of sugar beet divided by the average yield level. The yield level is different for different regions within a MS, so that a range is indicated. In regions with higher average yield levels, the VCS amount per tonne of beet is lower and vice versa;

f) VCS support per tonne of sugar beet compared with the sugar beet price paid in 2015/2016 (excluding the VCS payments). Ranges in calculated results are due to differences in productivity between regions within the MSs;

g) Finland is authorised to provide a national support payment of up to 350 euro/ha to its sugar beet growers since its EU accession in 1995 . According to EP Regulation 1308/2013 Art. 214 this payment is for sugar beet only. Direct payments in general are not affected (excluded).

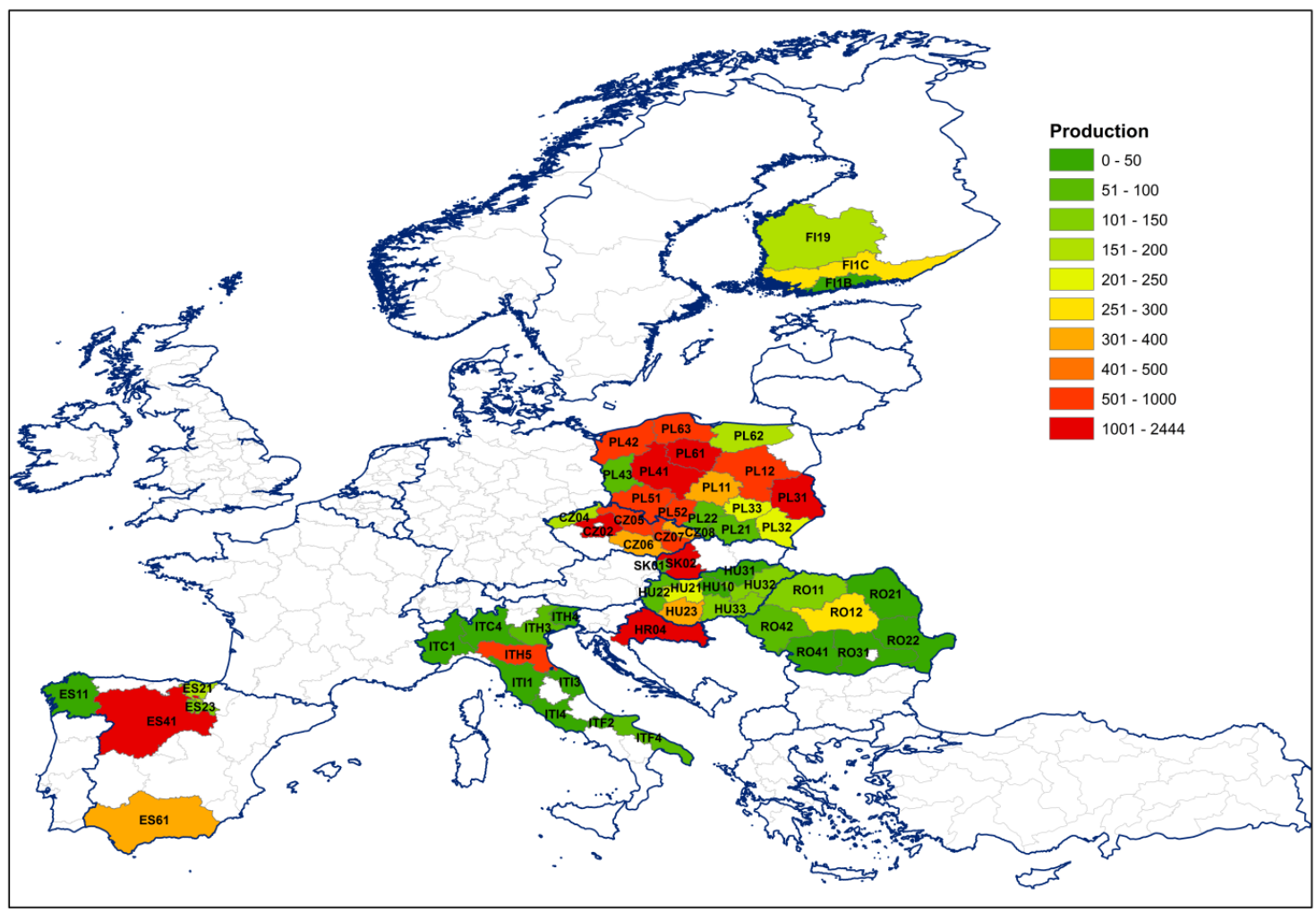

Map 3.4

Total sugar beet production in 60 regions of the VCS-MSs $(* 1,000$ tonnes of sugar beet) in 2015 


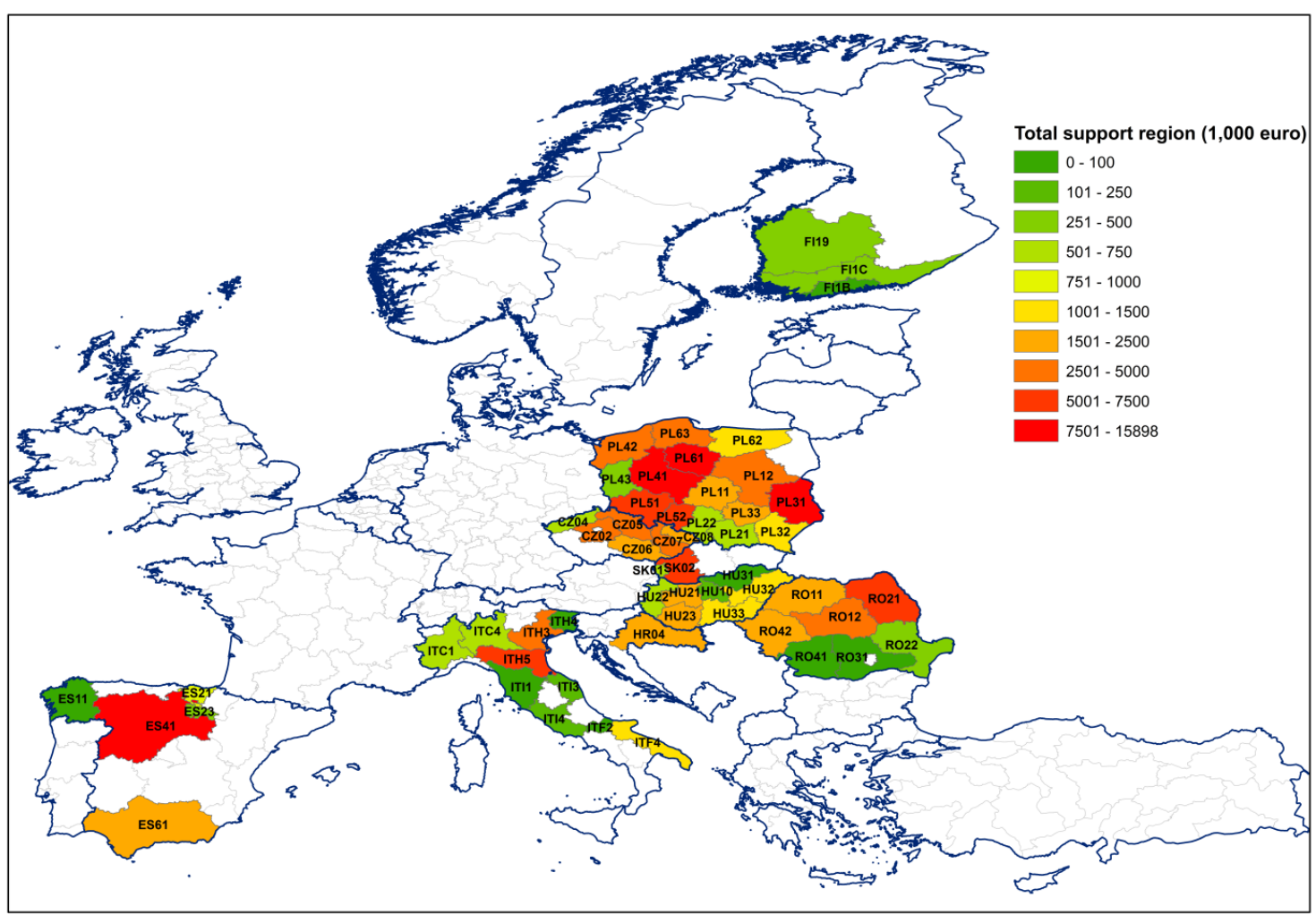

Map 3.5

Total amount of VCS for sugar beet received per region in the VCS-MSs in 2015

\subsection{Large number of small sugar beet growers in VCS-MSs}

The VCS-MSs counted in 2013 more than 70,000 sugar beet growers, being 45\% of the total number of EU sugar beet growers (more than 150,000 growers; Appendix 3). The number of growers per MS and the size distribution were very different among MSs. Poland held more than half of the sugar beet growers in the VCS group: more than 40,000, with the highest share of growers in the size class 1020 ha of sugar beet. Slovakia on the other hand counted 190 growers in 2013, of which 180 grew more than 100 ha of sugar beet. On average, VCS-MSs tended to have lower sugar beet areas per farm compared to other MSs (Table 3.2). As a consequence, in the VCS-MSs, lower shares of total sugar beet area were found in categories with higher sugar beet area per farm (Table 3.3).

Table 3.2 Sugar beet farm size distribution in the VCS-MSs compared with the EU in total (in 2013; more detailed data in Appendix 4)

\begin{tabular}{lccccccc} 
Group of MSs & \multicolumn{1}{c}{} & \multicolumn{2}{c}{ Distribution of sugar beet area per farm (ha) } & Total \\
\cline { 2 - 6 } & $<20$ & $20-29.9$ & $30-49.9$ & $50-99.9$ & $>100$ & 7 & 100 \\
\hline Total VCS-MSs & 59 & 13 & 12 & 9 & 20 & 24 & 100 \\
\hline Total EU & 31 & 10 & 14 & &
\end{tabular}

Source: Eurostat, adapted by Wageningen Economic Research.

Table 3.3 Total sugar beet area per sugar beet farm size category in the VCS-MSs compared with the $E U$ in total (in 2013; more detailed data in Appendix 5)

\begin{tabular}{lccccccc} 
Group of MSs & \multicolumn{5}{c}{ Distribution of sugar beet area over area classes (ha) } \\
\cline { 2 - 6 } & $<20$ & $20-29.9$ & $30-49.9$ & $50-99.9$ & 100 \\
Total VCS-MSs & 14 & 8 & 11 & 14 & 53 \\
\hline Total EU & 5 & 4 & 8 & 18 & 65 \\
\hline
\end{tabular}

Source: Eurostat, adapted by Wageningen Economic Research. 


\subsection{Synthesis: How big is the problem?}

The overall picture from the analysis is as follows:

- There are 60 regions in ten VCS-MSs with significant sugar beet areas;

- In these regions sugar beets are grown under very different climatic conditions, varying from dry and hot in Spain, Italy and Greece, partly compensated for with irrigation or growing winter beets (in Spain), to cold and rainfed (Finland and parts of Poland);

- In the ten MSs, 71,000 sugar beet growers were involved or $45 \%$ of the total number of growers in the EU;

- In 2015, they produced 24.5 million tonnes of sugar beet or $22 \%$ of the EU-production. In that year, the ten VCS-MSs harvested 410,000 ha sugar beet in total (29\% of the total EU area), whereas the potential area for VCS was 497,000 ha. In 2016 , the harvested area was estimated at 421,000 ha, so that 76,000 ha were still 'white spots'. These white spots were relatively large in Greece $(8,000$ ha out of 13,400 ha) and Hungary $(7,000$ ha out of 20,200 ha) and in absolute terms also in Italy (29,000 ha out of 62,300 ha).

- In the VCS-MSs, the average sugar beet area per grower is smaller than in the other sugar beet growing MSs and they have lower sugar beet yields per ha. ${ }^{7}$

\subsubsection{VCS support for sugar beet in perspective}

Figure 3.5 shows the share of VCS of the total Direct Payments in 2015. This share was not only applied to sugar beets, but also to other sectors as shown in Table 1.1. In that year, 4.1 billion (or $9 \%$ ) of the total direct payments (45.4 billion euro) were paid as coupled support.

In 2015 , the maximum area for coupled support for sugar beet was 497,200 ha. However, only 410,000 ha of sugar beet was really registered for VCS. The maximum amount of support was 176 million euro (or 354 euro per ha), which was $4.3 \%$ of the total VCS envelope or $0.4 \%$ of the Direct Payments in that year. Defending VCS, one could say that this figure was 'only' $0.4 \%$, which seems a relatively small amount. However, an average VCS amount of 354 euro/ha is relatively high compared to the direct payments per ha, as shown in Figure 3.4.

In 2015 , the 60 selected regions received 151 million euro of VCS or $86 \%$ of the available amount Appendix 3).

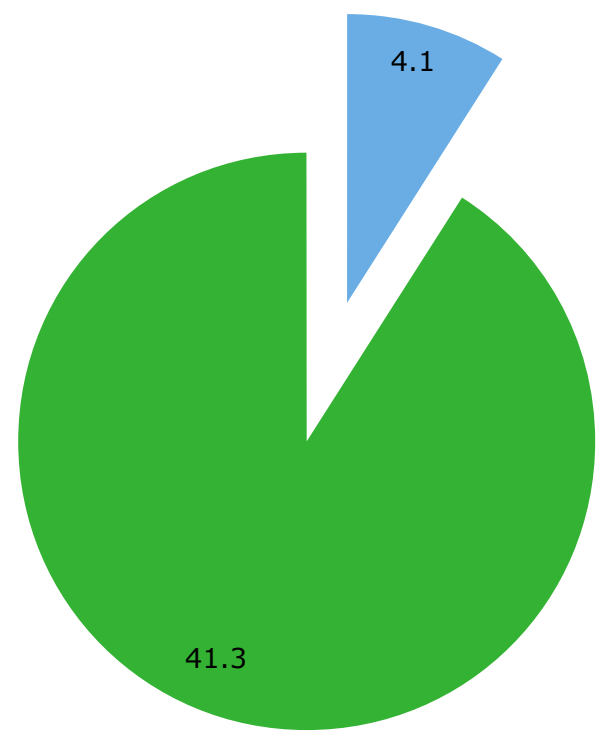

Direct Payments

- Voluntary Coupled Support

Figure 3.5 Share of VCS from the Direct Payment budget (45.4 billion euro, 2015)

Source: http://ec.europa.eu/agriculture/sites/agriculture/files/direct-support/directpayments/docs/voluntary-coupled-support_en.pdf

\footnotetext{
7 In general, sowing and harvesting on farms with relatively small sugar beet areas are carried out by contract workers or cooperatives. This can be planned in an efficient way, in many cases even more efficiently than on larger farms using their own sowing and harvesting equipment. Therefore, a smaller sugar beet area does not always lead to a lower profitability per ha.
} 


\subsubsection{VCS support changes direct support levels in relevant regions}

As shown in Figure 3.4, a VCS support of 354 euro per ha significantly changes the ha support per ha of sugar beet. A VCS for sugar beet will increase the average overall payments per ha in regions with relatively large sugar beet areas and possibly decrease the average overall payments per ha in regions with small or no sugar beet areas (apart from possible other VCS options adopted for other sectors). Thus, adopting a VCS can lead to changes in the regional distribution of direct payments within MSs. The reverse side of the medal is, that the general level of direct payments decreases when part of the budget is allocated to VCS. The higher the share of VCS in a MSs, the more VCS payments have to be compensated for by lower direct payments. Adopting a VCS scheme will certainly affect regional economies and most probably also sugar beet areas, which will be further elaborated on in Chapters 4 and 5 .

The picture for the 60 major sugar beet growing areas in 2015 is:

- Four regions received more than 10 million euro (three in Poland, one in Spain);

- In 28 regions less than 1 million euro was received (mainly in Finland, Italy and Greece).

- Within MSs there are large differences in total VCS paid.

Although all VCS-MSs, except for Slovakia, stayed in 2015 under the restrictions of maximum areas and amounts, it remains to be seen whether they do so in future. 


\section{$4 \quad$ Sugar beet as a competitive crop}

\subsection{Comparison of SOs in different MSs and specifically in VCS-MSs}

\subsubsection{Results of the comparison}

Table 4.1 gives a list of SO-data in the five non-VCS-MSs with the highest sugar beet production. For most MSs, cereals and rapeseed are the two major competitors in the cropping plan, which were therefore included in this analysis. The values per crop were different for the five MSs, but in all cases the SO of sugar beet was at least 900 euro/ha higher than the SO of cereals and rapeseed. The average SOs of sugar beet, cereals and rapeseed in $2010^{8}$ were 2,500, 1,400 and 1,300 euro per ha, respectively. The direct and operational costs of sugar beet are probably 500 euro/ha higher than for cereals and rapeseed (KWIN, 2015; FADN), but will not close the gap in SOs of more than 900 euro/ha. As a consequence, farmers in the five MSs will try to maximise the sugar beet area within the limits of sugar quota or delivery contracts, soil quality and rotational limits.

Table 4.1 Standard Outputs of sugar beets and alternative crops in non-VCS-MSs

\begin{tabular}{lrrr} 
MS & \multicolumn{2}{c}{ So (euro/ha) of crop: } \\
\cline { 2 - 4 } Belgium & Sugar beet & Cereals & Rapeseed \\
\hline France & 2,932 & 1,680 & 1,019 \\
\hline Germany & 2,540 & 1,292 & 1,272 \\
\hline Netherlands & 2,362 & 1,341 & 1,443 \\
\hline United Kingdom & 3,150 & 1,530 & 1,180 \\
\hline NoN-VCS a) & 2,255 & 1,408 & $\mathbf{1 , 4 0 4}$ \\
\hline
\end{tabular}

Unweighted averages over the five MSs.

Source: Eurostat, adapted by Wageningen Economic Research.

In Table 4.2 (and Figure 4.1), a similar list for the VCS-MSs is given. Additionally, this table contains the VCS support per ha sugar beet and the sum of SO and VCS-support per ha of sugar beet. In the VCS-MSs the SO of sugar beet is on average 1,950 euro/ha, which is more than 500 euro/ha lower than in the non-VCS-MSs. ${ }^{9}$ When the VCS is included in the payments per ha, on average 330 euro/ha, then the difference with the Non-VCS-MSs is only 230 euro/ha. On average, sugar beet growing in the VCS-MSs can compete with sugar beet growing in the non-VCS-MSs.

At the same time, the SOs for cereals and rapeseed are in the VCS-MSs lower than in the five MSs without VCS (except for cereals in Italy; the high SO-value there may be caused by the (higher) price of durum wheat). As a consequence, the difference in SO between sugar beet on one side and cereals and rapeseed on the other is bigger in the VCS-MSs (always higher than 700 euro and higher than

\footnotetext{
8 For a fully up-to-date analysis, price decreases since 2010 have to be taken into account: 1 ) The sugar price in the period 2013-2017 was on average 462 euro/tonne compared to 594 euro/tonne in the period 2008-2012, a decrease of $15 \%$; 2) the average cereal price decreased from 192 euro/tonne in the period 2008-2012 to 168 euro/tonne in the period 2013-2017 a decrease of $12.5 \%$. As a consequence, the difference between the SOs of sugar beet and cereals may have decreased a little, but not so strong that the analysis and conclusions of this section would significantly change.

9 Spain, Italy and Greece have an SO value comparable or even higher than the five non-VCS-MSs but may have higher irrigation costs (subsidies on irrigation not taken into account).
} 
600 euro/ha, respectively $)^{10}$ than in the five MSs without VCS. For cereals, the difference in the VCSMSs was 1,140 excluding VCS and 1,505 euro/ha including VCS. For rapeseed, the difference in the VCS-MSs was 1,118 excluding VCS and 1,483 euro/ha including VCS. For the non-VCS-MSs, these differences were 1,106 and 1,211 euro/ha for cereals and rapeseed, respectively. Assuming that the direct and operational costs are 500 euro/ha higher for sugar beet than for cereals and rapeseed, sugar beet is still competitive compared to these alternatives. The gross margins taking into account both direct and operational costs are on average 600 euro/ha higher without VCS and almost 1,000 euro/ha including VCS. Then, provision of VCS support to sugar beet growing is not required to make sugar beet a competitive crop compared to the alternatives.

Table 4.2 Standard Outputs sugar beets and alternative crops in VCS-MSs including Lithuania

\begin{tabular}{|c|c|c|c|c|c|c|c|}
\hline \multirow[t]{3}{*}{ MS } & \multicolumn{5}{|c|}{ SO (euro/ha) of crop: } & & \\
\hline & \multirow[t]{2}{*}{ So sugar beet } & \multirow{2}{*}{$\begin{array}{r}\text { VCS sb } \\
\text { a) }\end{array}$} & \multirow{2}{*}{$\begin{array}{r}\text { so sb incl ves } \\
\text { b) }\end{array}$} & \multirow{2}{*}{$\begin{array}{r}\text { So Cereals } \\
\text { c) }\end{array}$} & \multicolumn{3}{|c|}{ SO Rapeseed Difference with SO incl VCS } \\
\hline & & & & & & Cereals & Rapeseed \\
\hline Croatia & 1,819 & 121 & 1,940 & 934 & 965 & 1,006 & 975 \\
\hline Czech Republic & 1,993 & 267 & 2,260 & 826 & 1,060 & 1,434 & 1,200 \\
\hline Finland d) & 936 & 67 & 1,353 & 561 & 450 & 792 & 903 \\
\hline Greece & 2,494 & 374 & 2,868 & 406 & 1,224 & 2,462 & 1,644 \\
\hline Hungary & 1,937 & 396 & 2,333 & 774 & 859 & 1,559 & 1,474 \\
\hline Italy & 2,963 & 276 & 3,239 & 1,529 & 630 & 1,710 & 2,609 \\
\hline Lithuania & 1,750 & 77 & 1,827 & 681 & 731 & 1,146 & 1,096 \\
\hline Poland & 1,647 & 384 & 2,031 & 871 & 941 & 1,160 & 1,090 \\
\hline Romania & 1,245 & 600 & 1,845 & 530 & 613 & 1,315 & 1,232 \\
\hline Slovakia & 1,662 & 390 & 2,052 & 831 & 955 & 1,221 & 1,097 \\
\hline Spain & 2,778 & 420 & 3,197 & 811 & 592 & 2,386 & 2,605 \\
\hline vCS-MSs e) & 1,947 & 330 & 2,277 & 807 & 829 & 1,505 & 1,483 \\
\hline NON-VCS-MSs f) & 2,510 & 0 & 2,510 & 1,404 & 1,299 & 1,106 & 1,211 \\
\hline
\end{tabular}

a) The VCS support per ha (the 'planned' amount; see Section 3.2);

b) The sum of the SO 2010-value and the VCS support per ha;

c) Some MSs (Greece, Spain, Finland, Italy and Lithuania) had also VCS payments for cereals, but these never exceeded 60 euro per ha;

d) For Finland, the value 'SO sb incl VCS' includes an extra coupled support of sugar beet growing (apart from VCS) of 350 euro/ha;

e) Unweighted averages over the MSs in the list excluding Lithuania;

f) Unweighted averages over the MSs in Table 4.1.

Source: Eurostat, adapted by Wageningen Economic Research.

The conclusion of this analysis is that sugar beet is a competitive crop in all VCS-MSs compared to cereals and rapeseed, even without a VCS premium (see also Figure 4.1). The only exception is Finland, where a relatively small VCS of 67 euro/ha plus an additional coupled premium for sugar beet growing of 350 euro/ha improved its competitiveness towards cereals and rapeseed. For the other VCS-MSs, the introduction of VCS could not be explained from the current SOs for sugar beet, cereals and rapeseed. It is not likely, that farmers would have given up growing sugar beet and that sugar factories would have received less sugar beets when the VCS would not have been adopted.

\footnotetext{
${ }^{10}$ The only exception to this picture is Finland, where the differences with cereals and rapeseed were only 375 and 486 euro/ha without VCS, respectively, and 792 and 903 euro/ha including VCS and additional coupled support. Nevertheless, assuming the same difference in direct and operational costs of 500 euro/ha, sugar beet is even here more competitive than cereals and rapeseed. Finland applied a 'planned' VCS of 56 euro/ha in cereal growing, but that does not significantly change the competitive power of sugar beet compared to cereals.
} 


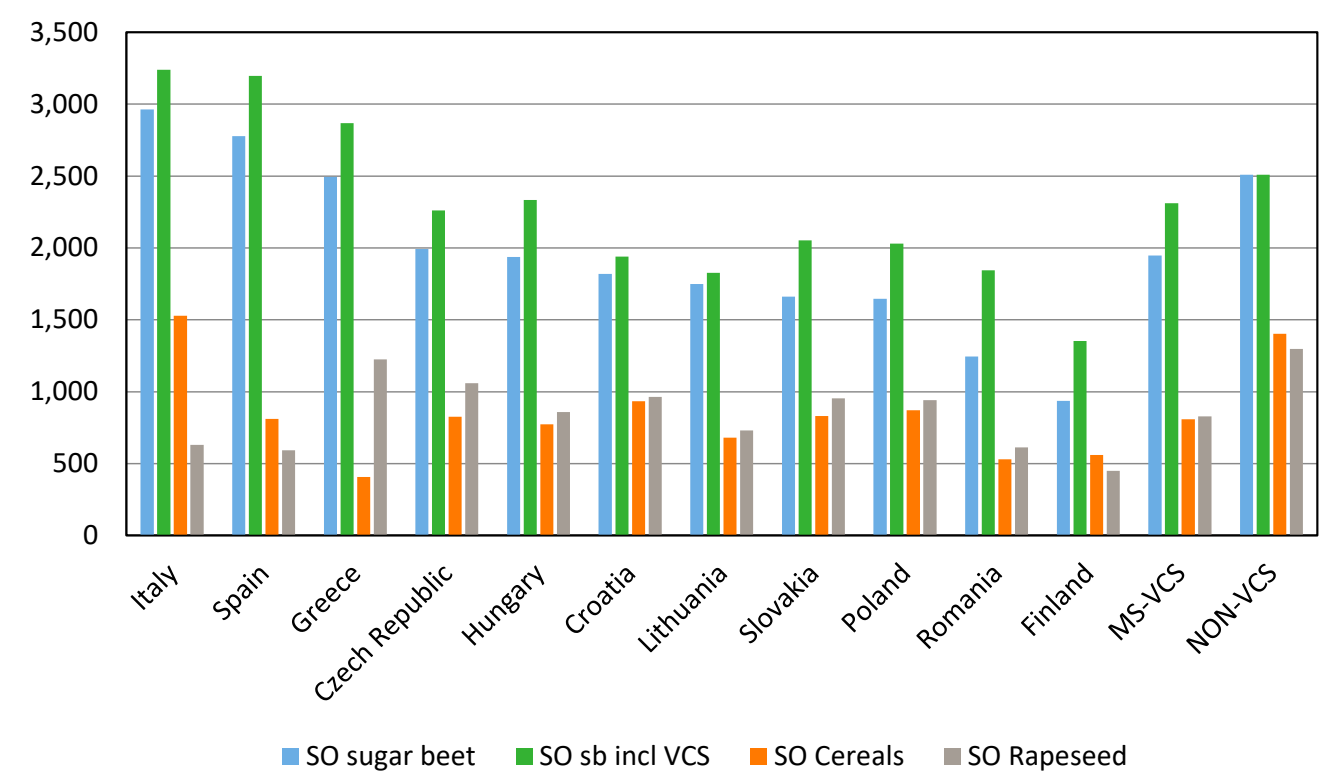

Figure 4.1 Standard Output values of sugar beet, both without and with VCS, and cereals and rapeseed a)

a) MSs-VCS and NON-VCS give unweighted averages for the ten VCS-MSs and the five MSs without VCS, respectively.

Sources: Eurostat and EC (2015).

A more extensive comparison of SOs is given in Appendix 8, focusing on the main sugar beet growing regions within the VCS-MSs. The picture is similar as above. In some countries or regions, potato could be a serious alternative for sugar beet. However, in practice both crops can be perfectly combined at arable farms. There will not be much competition between these crops due to rotational limits of both crops (maximum intensity of both crops is one-in-four years). Where the soil (few stones, enough depth), the slope of the land (not too steep) and the water availability (not too dry) permit potato growing, sugar beet growing will also be profitable. Cereals and rapeseed will lose the competition with sugar beet and potato.

\subsubsection{Discussion of the SO-comparison method}

\section{Standard Output}

The results regarding the competitiveness of sugar beets in the concerning MSs are highly dependent on the accuracy of the calculated level. The advantages of the use of the Standard Outputs are evident: in the first place, they are calculated by a clear instruction, in order to prevent differences in meaning of the values between crops or MSs. A second advantage is that the Standard Output value is available for nearly all possible crops. That also implies that the standard value of sugar beets is calculated by the same rule as for the alternative crops. The third advantage is that the Standard Output is available on a regional level. This implies that the Standard Output of sugar beets can be compared with the Standard Output of the alternative crops, under comparable regional conditions. The fourth advantage is that the Standard Output is calculated as a five year average, leading to an acceptable stability of the value during time, corrected for occasional price or yield fluctuations.

There are also some difficulties in using the Standard Output as an indicator for the competitiveness. A better indicator would be the Standard Gross Margin of the crops. In the gross margin the direct crop costs, like cost of seed, fertiliser and crop protection, are discounted. In this study, is it implicitly assumed that the direct crop costs do not significantly differ within a region. A second disadvantage is that the SO values are somewhat outdated. The last available values is the SO 2010, based on the years 2008-2012. The next standards (SO 2013) will not be available before 2018. For Greece, the SO 2010 is not published. That is why for Greece the SO 2007 is used in the calculations. Another practical problem is the value of the Standard Outputs per region are barely verifiable, as the underlying yields and prices are not given. 
As indicated in Chapter 2 (Methodology), an alternative would have been to use FADN data on returns per ha of crop of sugar beet growing farms. Relative to that approach the SO approach followed here may lead to a slight overestimation of the differences for regions characterised by a relatively high diversity in soil characteristics, specifically regarding their ability to grow sugar beets.

\section{Irrigation}

In a number of regions, a part of the sugar beets are irrigated to achieve higher yields. The amount of irrigation depends on several circumstances, e.g. the local drought and the availability of water. In the Mediterranean MSs irrigation of sugar beets is more applied than elsewhere. In Greece and Spain $80 \%$ to $90 \%$ of the sugar beets are irrigated. In Italy this is the case for about $40 \%$ of the area. The applied method to judge the competitiveness is valid under the condition that the direct costs of the crops between the MSs is similar. Strictly seen the Standard Output should be corrected by the costs of irrigation to make a fair comparison. For several reasons such a correction is not applied:

1. The costs of irrigation are very unclear. They differ from region to region and from farm to farm due to differences in price of water, availability of water, intensity of irrigation per ha, and the type of equipment.

2. In some regions water is free, while in other regions the authorities levy a tax on the use of groundwater.

3. If sugar beets are irrigated, this is often also the case for many alternative crops. This levels out possible differences in competitiveness. In general, for potatoes more irrigation is applied than for sugar beets; cereals and rape seed are generally less irrigated.

Sugar beets grown as a second crop

In Spain part of the sugar beets are grown in wintertime, between two summer crops. In this study it is assumed that winter growing of sugar beets is indeed a favourable activity, but it does not have a significant effect on the competitiveness. On one hand the economy is effected advantageously due to saving the costs of land. On the other hand the yield of the previous and the following crop can be lower as a result of respectively compulsory earlier harvesting or later sowing of the crops.

\subsection{Other reasons for VCS support in different countries?}

\subsubsection{Low yields}

Figure 4.2 shows the same data as Figure 3.4 but now the productivity (in tonnes of sugar beet per ha) has been added, providing the following observations:

- Croatia has low yields and a low VCS amount;

- Romania and Finland have low yields and high VCS amounts;

- Spain had high yields and a high VCS amount.

For the ten VCS-MSs as a whole, there is apparently no relationship between sugar beet yields and the amount of VCS per ha. Romania could have a reason to increase the profitability of sugar beet, but an amount of 600 euro per ha is relatively high, especially when yields are low (up to $50 \%$ of the returns; see Table 3.1). More detailed data on the sugar beet yields throughout the EU are given in Appendix 8. Low yields do not seem to be a widely used reason for the height of the VCS support. 


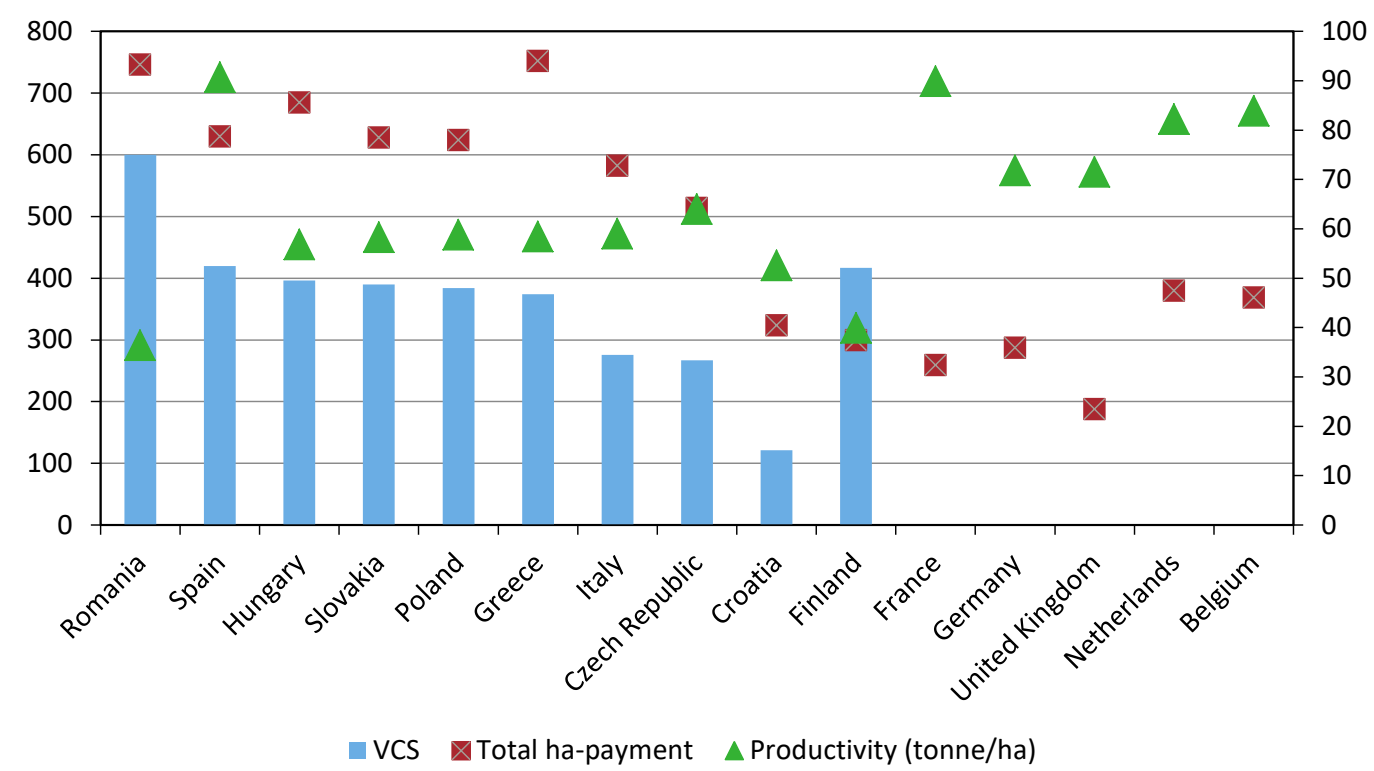

Figure 4.2 VCS payments (in 2015), average total direct payments (in 2013) and productivity (averages 2011 - 2015) per ha sugar beets in different MSs (the VCS-MSs and the largest sugar beet growing MSs outside the VCS) a)

a) For Finland, the VCS amount is including an additional coupled premium for sugar beet growing besides the VCS support sec.

Sources: EC (2015) and EP (2013).

\subsubsection{Low prices}

Another reason to grand VCS could be a lower price of sugar beet in the VCS-MSs. Table 4.3 shows the average sugar beet prices over the period 2010 - 2015. The average sugar beet price strongly varies between MSs, both in the group of VCS-MSs and in the five Non-VCS-MSs in this comparison. France and Greece had the lowest sugar beet prices (27 euro/tonne), the Netherlands and Italy the highest (50 and 43 euro/tonne, respectively). ${ }^{11}$ On average, the sugar beet prices were not significantly lower in the VCS-MSs than in the non-VCS-MSs (34.2 and 36.0 euro/tonne). So, low prices do not seem to be a reason for VCS support.

Table 4.3 Average sugar beet prices (2010-2015) in the VCS and five non-VCS-MSs

\begin{tabular}{llll} 
VCS-MS & Price sugar beet (euro/tonne) & Non-VCS-MS & Price sugar beet (euro/tonne) \\
Croatia & 34.1 & Belgium & 28.4 \\
\hline Czech Republic & 30.3 France & 37.7 \\
\hline Finland & 34.6 Germany & 49.6 \\
\hline Greece & 27.0 & The Netherlands \\
\hline Hungary & 36.3 United Kingdom & 37.6 \\
\hline Poland & 31.7 & \\
\hline Romania & 36.2 & \\
\hline Slovakia & 36.5 & \\
\hline Spain & 31.8 & \\
\hline Italy & 43.0 & \\
\hline Lithuania & 34.1 & \\
\hline Average VCS-MSs a) & 34.2 & Average non-VCS-MSs a)
\end{tabular}

a) Non-weighed averages over ten and five MSs, respectively (Lithuania excluded).

Source: Eurostat, adapted by Wageningen Economic Research.

\footnotetext{
${ }^{11}$ In Italy, a national price subsidy was granted (unlike the Netherlands, where the sugar beet price benefited from the good results of Cooperative Cosun in their potato, cichory and other daughter companies).
} 


\subsubsection{Low sugar beet farmer incomes}

A third reason could be that farmers in certain MSs have such low incomes, that they could go bankrupt, leaving the sugar industry without sugar beet supply. Figure 4.3 shows large differences in family farm income in the MSs studied, both in the VCS and in the non-VCS-group. The average income in the period 2011-2015 was for Spain, Hungary, Italy and Czech Republic at the same level as in France (20,000 euro). For the other VCS-MSs, the income was indeed relatively low $(12,000$ euro at maximum) compared with the unweighted average income in the five non-VCS-MSs (36,000 euro per year). But also for the VCS group as a total, the average income was significantly lower $(14,000$ euro) than in the other five MSs. Therefore, low income could be a reason for different VCSMSs to care of the income position of their farmers. However, for a complete picture of the income situation, more details on the exact composition of the income data and other sources of income at the family farms involved would be required. But still if the total income situation would be structurally insufficient, there are serious doubts whether a coupled support measure is an appropriate instrument to solve the income problem, as is further elaborated on in chapter 6 .

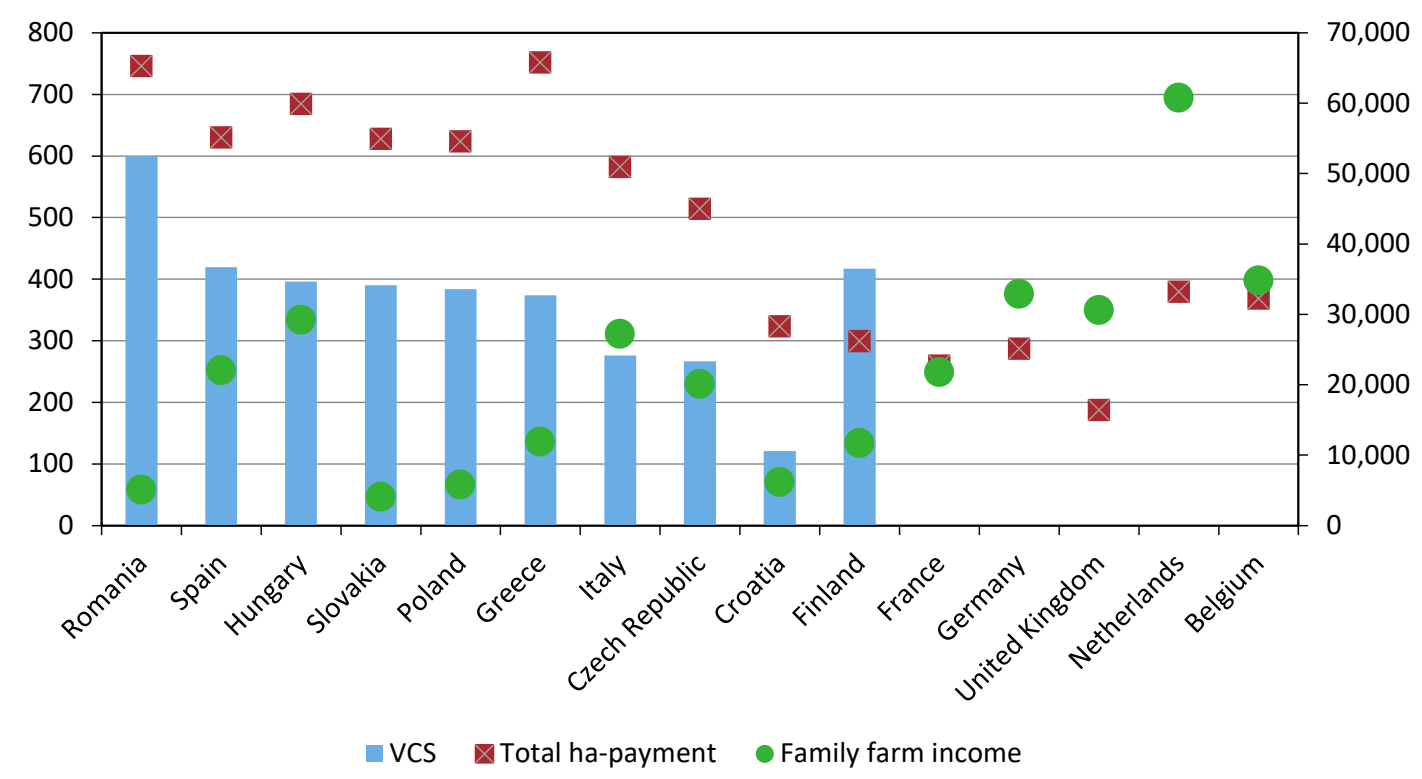

Figure 4.3 VCS-payments (in 2015) and average total direct payments (in 2013) per ha of sugar beet and family farm income of arable farmers (averages over 2011-2015) in different EU MSs (the VCS-MSs and the largest sugar beet growing MSs outside the VCS).

For Finland, the VCS amount is including an additional coupled premium for sugar beet growing besides the VCS support sec.

Sources: EC (2015), EP (2013) and Eurostat, adapted by Wageningen Economic Research.

An overview of the different indicators in this analysis, focusing on the 60 main sugar beet growing regions within the VCS-MSs is given in Appendix 10. In this overview, stronger and weaker regions can be discerned. In stronger regions, sugar beets have higher (than average) yields per ha, higher SOs, larger sugar beet areas and higher farm family incomes. When a MS decides to adopt VCS for sugar beet growing, regions with relatively large sugar beet areas will receive most of the support, expressed as the share of the total VCS envelope allocated to sugar beet production. Since VCS support is a part of the total envelope of direct payments in Pillar 1 of the CAP, when MSs grant coupled support the level of decoupled support per ha will decrease. As such the granting of voluntary coupled support to specific products will affect all regions in that it lowers the height of the basic payment per hectare. As a consequence, adopting VCS for sugar beet will lead to a regional shift of direct payments towards regions with relatively large areas of sugar beet.

Regions with relatively large sugar beet areas appear to have in general also high sugar beet yields. The conditions for sugar beet growing are apparently favourable in these regions. The cropping 
intensity of sugar beet in these regions may already be so high, that those regions will not necessarily be the ones with the highest growth in sugar beet area due to the introduction of VCS. In regions with lower sugar beet yields, there may be more land for increased sugar beet cultivation and a certain VCS amount per ha may have a relatively greater impact on an increased or stabilised sugar beet area in those regions than in the high-yielding regions. That is in accordance with the VCS background. However, in case the cropping intensity still leaves space for expansion of the sugar beet area, then the sugar beet area is likely to increase most in high-yielding regions.

\subsection{Conclusions}

- The sugar beet yields in the VCS-MSs are mostly lower than in the five non-VCS-MSs;

- The sugar beet prices are comparable in and outside the VCS-MSs;

- As a consequence, the Standard Output of sugar beet within the VCS-MSs is on average lower than in the other MSs;

- However, the differences between the SO of sugar beet on one side and the SOs of the alternative crops (cereals and rapeseed) in the VCS-MSs are on average larger than in the non-VCS-MSs;

- Even when assuming 500 euro/ha higher direct and operational costs for sugar beet than for cereals and rapeseed, sugar beet is a strong competitive crop in all VCS-MSs, except for Finland;

- According to Eurostat, the incomes of field crop farmers in VCS-MSs are relatively low, certainly when compared with the non-VCS-MSs. If this picture is correct and complete, then the question is if a VCS for a in itself competitive crop is the correct and legitimate measure to take;

- No relationship between sugar beet yields and the amount of VCS per ha was found. 


\section{$5 \quad$ Modelling and VCS impact analysis}

\section{$5.1 \quad$ Introduction}

This chapter focuses on assessing the production and market impacts of voluntary coupled support. In order to evaluate the impact of the voluntary coupled support provided by MSs, a situation with and without such support needs to be compared.

The structure of this chapter is as follows. The coupled support impact simulation results are presented and discussed in Section 5.2. Section 5.3 provides concluding remarks and lists some of the limitations of the research.

\subsection{Coupled support impact simulation}

As explained in Chapter 2, an EDM approach was applied to simulate the effects of VCS in sugar beet growing. The data for the calibration of the model are presented in Table 5.1.

Figure 5.1 presents the simulated changes in sugar beet production due to VCS, i.e. the production with VCS-support minus the production without the VCS support. As the figure shows in terms of magnitude, Polish sugar beet production is the one which is most positively affected by the VCS. The increase in the effective price of sugar beets due to VCS is about $€ 8 /$ tonne, or an increase of about $30 \%$ of the price that would have prevailed without this support. Poland is one of the EU's big sugar beet producers, having a share of about $13 \%$ in the total sugar beet area in the EU. Other MSs with an increase in sugar beet production include Italy, Czech Republic, Hungary and Romania. For the other MSs, the simulated increases in production due to the VCS support are however, more limited, even though the VCS rates (e.g. Romania) may be even higher than that of Poland. The reason is that the shares in EU production of all other MSs applying VCS are substantially lower than that of Poland.

The increase in sugar beet supply due to the VCS leads to an induced price decline (Figure 5.2). On average, this induced price decline varies between $3.5 \%$ and 5.5\%. For the VCS-MSs, the support rates usually dominate the induced counteracting price decline effect. For MSs without VCS support, the sugar beet growers face a negative price impact. This induces the sugar beet growers in these countries to reduce their supply in accordance with their supply curves. As Figure 5.2 shows this leads to reductions in the supply of sugar beets in France, Germany and the Netherlands by 250, 184 and 74 thousand tonnes respectively. In terms of the production of sugar beets in these MSs, these reduction amounts on average less than $1 \%$. 
Table 5.1 Overview of quota and production data used to calibrate EDM

\begin{tabular}{|c|c|c|c|c|c|c|c|c|}
\hline MS & $\begin{array}{l}\text { Sugar quota } \\
\text { (ton) }\end{array}$ & $\begin{array}{c}\text { Isoglucose } \\
\text { production } \\
\text { (tonne) }\end{array}$ & $\begin{array}{l}\text { Sugar yield } \\
\text { 2016-17 } \\
\text { (tonne/ha) }\end{array}$ & $\begin{array}{c}\text { Sugar beet } \\
\text { area } 2016- \\
17\end{array}$ & $\begin{array}{c}\text { Sugar } \\
\text { production } \\
\text { campaign } \\
2016-17 \\
(1,000 \\
\text { tonnes) }\end{array}$ & $\begin{array}{c}\text { Sugar } \\
\text { content ( } 5 \\
\text { yr average) } \\
\%\end{array}$ & $\begin{array}{c}\text { Prices } \\
\text { (calculated, } \\
\text { euro/tonne } \\
\text { ) }\end{array}$ & $\begin{array}{l}\text { Own price } \\
\text { supply } \\
\text { elasticities }\end{array}$ \\
\hline Belgium & 676,235 & 114,580 & 11.4 & 56.4 & 643.0 & 13.2 & 28.00 & 0.06 \\
\hline Bulgaria & & 89,198 & & & 0.0 & 6.5 & 28.00 & 0.50 \\
\hline Croatia & 192,877 & & 11.0 & 18.8 & 206.8 & 8 & 31.82 & 0.50 \\
\hline Czech Republic & 372,459 & & 11.9 & 52.3 & 622.4 & 10.2 & 36.52 & 0.50 \\
\hline Denmark & 372,383 & & 12.2 & 32.7 & 398.9 & 12.7 & 31.00 & 0.23 \\
\hline Germany & $2,898,256$ & 56,638 & 12.3 & 310.4 & 3817.9 & 11.4 & 36.00 & 0.22 \\
\hline Greece & 158,702 & & 6.0 & 5.3 & 31.8 & 6.6 & 34.96 & 0.50 \\
\hline Hungary & 105,420 & 250,266 & 9.4 & 13.7 & 128.8 & 7.8 & 35.19 & 0.50 \\
\hline Ireland & & & & & 0.0 & & 26.00 & 0.50 \\
\hline Italy & 508,379 & 32,493 & 7.8 & 32.4 & 252.7 & 11.2 & 33.49 & 0.90 \\
\hline Latvia & & & & & & & 26.00 & 0.23 \\
\hline Lithuania & 90,252 & & 9.7 & 14.7 & 142.6 & 9.5 & 32.25 & 0.23 \\
\hline Netherlands & 804,888 & & 13.1 & 66.8 & 875.1 & 13.7 & 36.00 & 0.33 \\
\hline Poland & $1,405,608$ & 42,861 & 10.3 & 202.9 & 2089.9 & 9.6 & 35.54 & 0.50 \\
\hline Sweden & 293,186 & & 10.8 & 30.1 & 325.1 & 10.6 & 27.00 & 0.23 \\
\hline United Kingdom & $1,056,474$ & & 12.7 & 70.6 & 896.6 & 13 & 34.00 & 0.11 \\
\hline Total & $13,529,618$ & 720,441 & & & & & & \\
\hline Total VCS-MSs & $3,539,933$ & 447,524 & & & & & & \\
\hline
\end{tabular}

Source: Quota information derived from EU legislation; yields and sugar contents based on Eurostat and CEFS statistics, prices based on Eurostat and own elaboration; supply elasticities based on literature and expert information (see also Methodology-chapter (2) for further details).

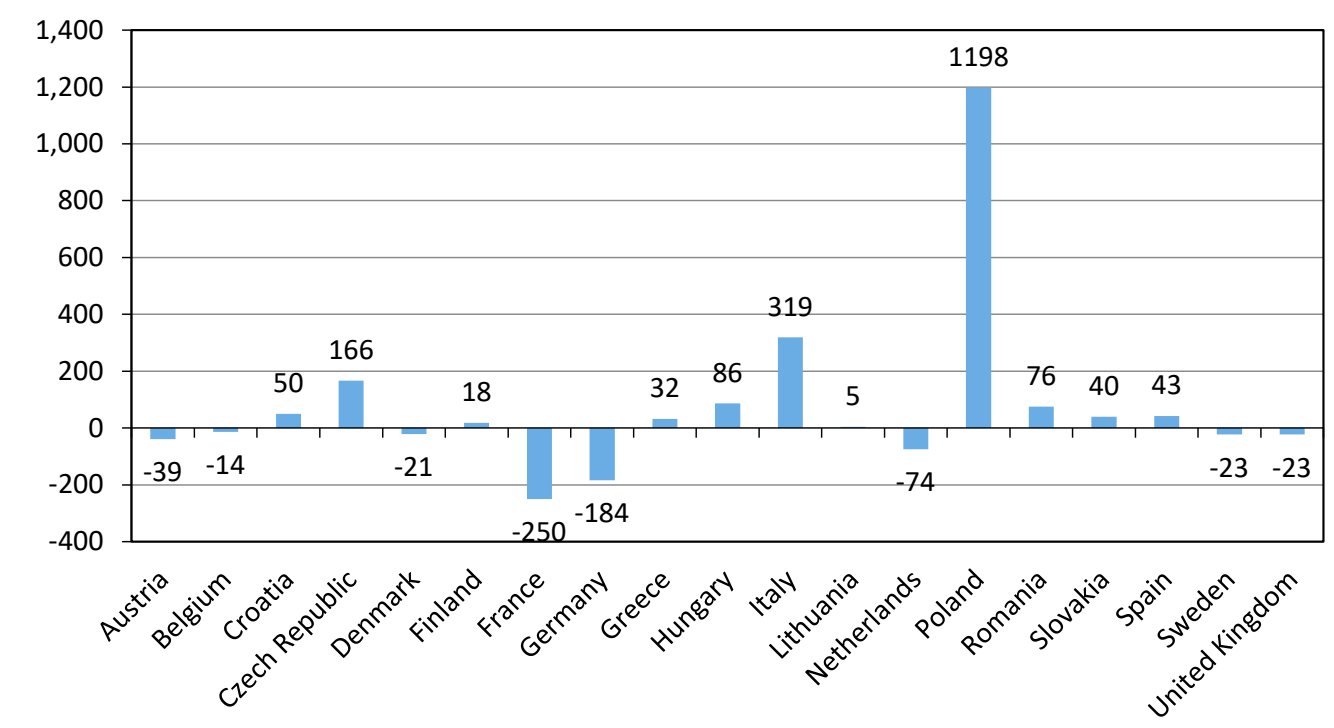

Figure 5.1 Simulated impact of VCS on EU sugar beet production, i.e. the production volume in the scenario with VCS support minus production volume in the scenario without VCS support (thousand tonnes)

Source: own model calculations. 


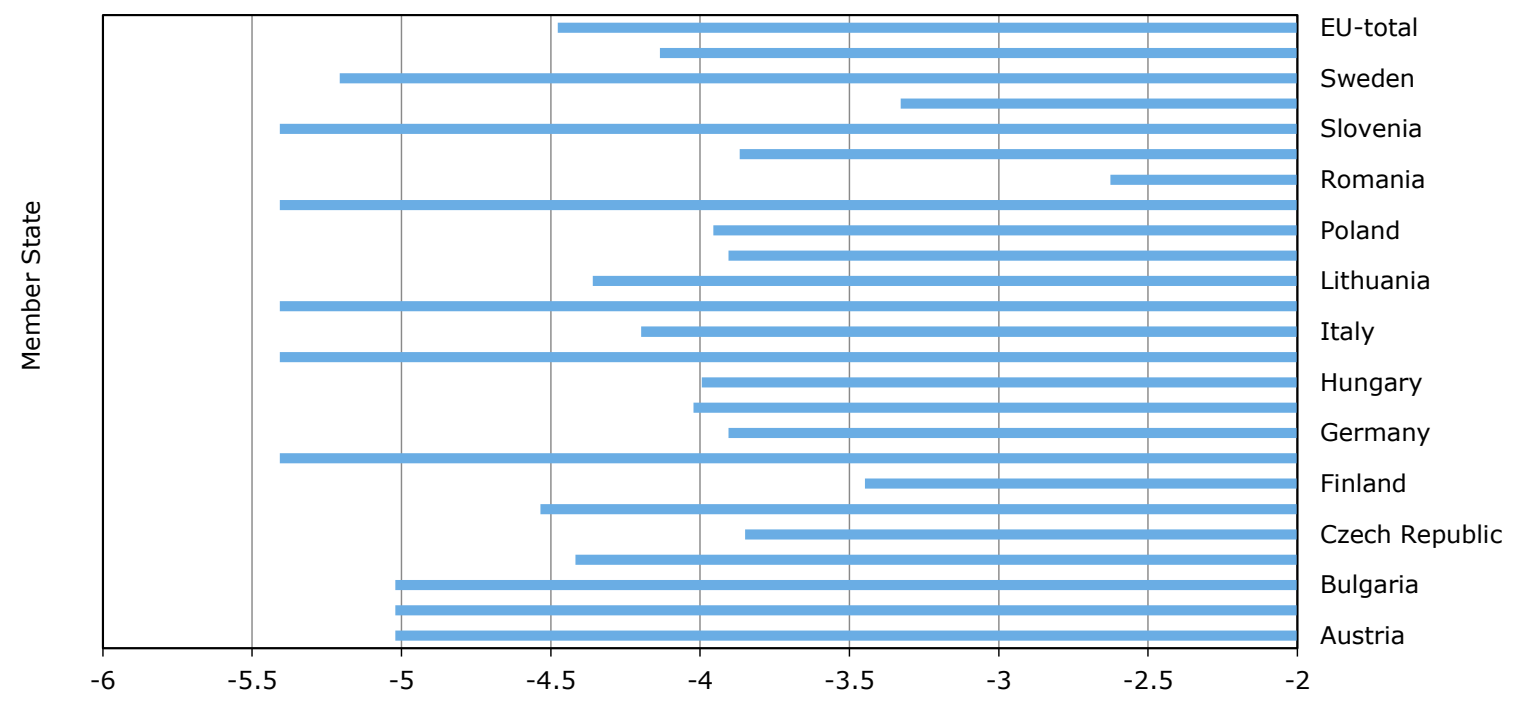

Percentage sugar beet price change

Figure 5.2 Simulated sugar beet price decline due to VCS at Member State level

It should be noted that the simulated calculations have a stylised character and are subject to several uncertainties (see Section 2.2.2 for details).

The monetary impacts are calculated in Table 5.2, where the total change is decomposed in three different impacts:

1. The revenue loss due to the price decline induced by the VCS (no change in production);

2. The revenue change due to the change in production due to VCS (which is likely to be negative for non-VCS-MSs and positive for VCS-MSs);

3. The revenue gain due to the VCS payments farmers receive.

At EU-28 level, the three effects of VCS are a 150.7 million euro loss, a 53.8 million euro gain and a 179.4 million euro gain respectively. Aggregating all effects the net gain at EU 28 level is about 85.4 million euro. VCS-MSs gain 219.1 million euro, whereas the non-VCS-MSs face a loss of 133.7 million euro (equivalent to 85.4-291.7 million euro). The MS gaining most is Poland ( +118 million euro) and the MS losing most is France ( -55.7 million euro). Germany loses about 38.3 million euro due to negative impacts of VCS on its sugar sector. ${ }^{12}$

\subsection{Concluding remarks}

On average, as a result of the VCS EU sugar beet production has been estimated to increase by about 1.3 percent, generating an induced price decline of about 4.5 percent. Sugar beet growers in VCS-MSs in general benefit, because of the additional payment or subsidy per tonne of sugar beet produced. Sugar beet growers in non-VCS-MSs are negatively affected, because of the induced price decline. The sum of all effects is a net gain at EU-28 level for the sugar beet growers, which amounts about 85 million euro. VCS-MSs gain 219 million euro, whereas the non-VCS-MSs face a loss of 133.7 million euro. The simulated results provide insight into the order of magnitude of the impacts of VCS on the EU sugar sector and their distribution over MSs.

\footnotetext{
${ }^{12}$ In these calculations, changes in land use has not been included. However, the major financial effect is the extra premium on the existing sugar beet area in the VCS-MS. This effect is much more important than the expansion of the sugar beet area and production.
} 
Table 5.2 Calculated monetary impacts (gain or loss) associated with the introduction of the VCS system for EU MSs per year

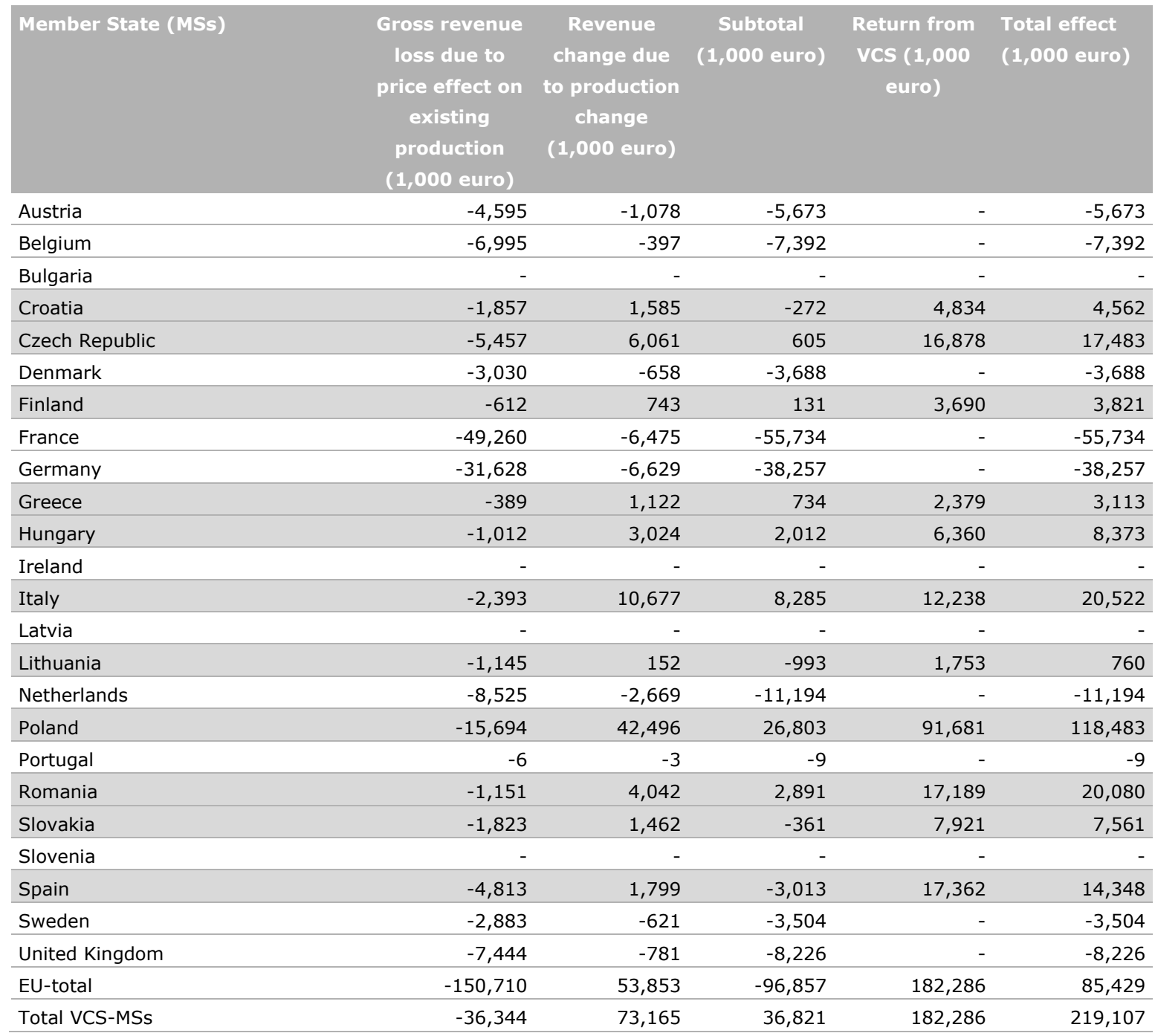

Source: own model calculations. 


\section{$6 \quad$ Legitimacy of VCS support}

\subsection{Introduction}

The 2014-2020 CAP reform has on the one hand continued in the direction of an increased market orientation (convergence of direct payments between MSs), while on the other hand it allowed MSs to couple direct payments to selected sectors. This option, which was voluntary, was implemented in the sugar beet sector in ten MSs. This has led to an asymmetric and uneven implementation of coupled payments between MSs. The previous chapters showed, that this support has an impact on each MS market, as well as on the aggregate EU market. Whereas the decoupled support shows a tendency to converge, the coupled support is diverging, which has positive as well as adverse impacts on production and prices. This raises the issue of coherence and motivates a further look into the aspects of this voluntary coupled support as it has been implemented in the sugar beet sector.

A number of research questions have been formulated with respect to the appropriateness and legitimacy of the voluntary coupled support:

1. Does VCS contradict the basic EU-principle of creating a level playing field?

2. Is it legitimate to support regions to go out of sugar (beets) in 2006 and to come back in business with VCS?

3. Does VCS lead to a stabilisation of the sugar beet area in 'weak' regions or to an increase in those regions and/or in stronger regions in the same MS?

4. How can VCS be applied without adverse production and market effects?

5. Are there reasons to deal with VCS differently in sugar beet than in other crops? E.g. export dependency, direct competition of sugar beet with other arable crops?

This chapter is structured as follows. First, the legal conditions and implemented voluntary coupled support are discussed (Section 6.2). Subsequently, the five research questions are answered (Sections 6.3 to 6.7 ), while Section 6.8 concludes with some closing remarks.

\subsection{Legal conditions and VCS support implementation}

According to EU Regulation 1307-2013, MSs are allowed to use part of their national envelope for direct payments for coupled support in certain clearly-defined cases. The resources that may be used for any coupled support should be limited to specific sectors or regions in a MS where specific types of farming or agricultural sectors are particularly important for economic, environmental and/or social reasons. The 'particular situations' refer to sectors that 'undergo certain difficulties' (cf. Article 52(3)) and to the extent necessary to 'create an incentive to maintain current levels of production in the sectors or regions concerned' (cf. Article 52(5)).

With respect to sugar beet production, Croatia, Czech Republic, Finland, Greece, Hungary, Italy, Poland, Romania, Slovakia and Spain in 2015 and 2016, plus Lithuania in 2017, decided to apply VCS to the sugar beet sector, with payments varying between $€ 81$ (Finland) and $€ 784$ (Romania) per hectare, although support is limited (e.g., in 2015 to 479,200 ha). As indicated in Map 3.1, the coupled payments tend to be granted in a generic way, applying to all sugar beet producing regions within a MS rather than targeted at specific regions facing difficulty (although Slovakia was an exception as it exceeded its limit in 2015). This may be due to the fact that the sugar beet area has generally declined in all sugar beet producing MSs during the last decade (see Figure 3.2).

Table 6.1 provides more detailed, country-level information on sugar beet. Eleven MSs implemented voluntary coupled support in 2017. Using the joint criteria of 'importance' and 'facing difficulties' (at the MS level), as referred to in EU Regulation 1307-2013, no MS would qualify to apply VCS as a 
generic country-wide support measure. When evaluating at a lower, regional level, results may be different, but this would then only justify regionally targeted VCS.

Table 6.1 Characteristics of voluntary coupled support provided by MSs, 2015

\begin{tabular}{|c|c|c|c|c|c|c|c|c|c|}
\hline & \multirow[t]{5}{*}{ MSs } & (1) & (2) & (3) & (4) & (5) & (6) & (7) & (8) \\
\hline & & $\%$ & Area & Area & vCS & Yield & vCs & estimated & VCS as $\%$ \\
\hline & & change & Limit & covered & $(\varepsilon / h a)$ a) & (tonnes/ha) & ( $\varepsilon /$ tonne) & price & price \\
\hline & & $2005-$ & ha) & ('000s & & & & & \\
\hline & & 2015 & & ha) & & & & & \\
\hline Czech Rep & & 13.8 & 62.4 & 53.6 & 289 & 59.4 & 4.52 & 32 & 14.1 \\
\hline Finland & & -12.0 & 14.8 & 12.5 & 81 & 32.8 & 2.03 & 32 & 6.3 \\
\hline Greece & & 4.1 & 13.4 & 4.9 & 523 & 52.3 & 8.96 & 26 & 34.4 \\
\hline Hungary & & -8.7 & 20.2 & 15.0 & 522 & 58.7 & 9.19 & 26 & 35.3 \\
\hline Italy & & -13.1 & 62.3 & 38.1 & 442 & 57.3 & 7.49 & 26 & 28.8 \\
\hline Slovakia & & 1.8 & 20.4 & 21.7 & 370 & 56.0 & 6.35 & 30 & 21.2 \\
\hline Spain & & 0.0 & 40.1 & 37.0 & 475 & 95.9 & 5.24 & 37 & 14.2 \\
\hline Lithuania b) & & 19.5 & 19.2 & 12.3 & 120 & 50.6 & 2.25 & 30 & 7.5 \\
\hline
\end{tabular}

a Source: DG Agriculture, EU Commission (2017).

b Lithuania introduced a VCS in 2017; area planted is authors' estimate.

Source: Authors calculations based on Eurostat and CEFS data; where price information was missing, a price equivalent to the estimated world market price of $€ 26 /$ tonne was used.

\subsection{VCS and the basic EU-principle of a level playing field}

As has been shown in Table 3.1 (and also in Figure 3.4) the coupled support is very unevenly distributed over MSs and their sugar beet growers. Up to now, 11 MSs implemented VCS support in the sugar beet sector, whereas eight other MSs with sugar beet production did not. The VCS-support rates per hectare and per tonne of sugar beets vary a lot between the VCS-MSs, ranging from about $€ 5$ to about $€ 50$ per tonne of sugar beets. As it has been argued in Chapter 5 , the price equivalent of the coupled support can be interpreted as either a mark-up to the market price of sugar beets or as a subsidy, reducing the effective (variable) costs of production of sugar beets. By affecting the cost of production level (or more generally the profitability of sugar beet growing) the competitiveness of sugar beet growers in VCS-MSs improves relative to their colleagues in the non-VCS-MSs). The uneven distribution of the support (see Table 3.1) also implies that within the group of MSs applying coupled support the relative competitiveness of their sugar sectors is affected.

Concluding, the voluntary coupled support measures as it is implemented by different MSs does conflict with the principle of the single market and a level playing field. MSs whose sugar beet sector competitiveness has been especially enhanced, are those with relatively high coupled support rates (measured in sugar beet incentive price equivalent), among which are Romania, Greece, Hungary, and Poland.

\subsection{Exit in 2006 and come back in business with VCS?}

From the legislation it can be derived that the aim of the voluntary coupled support measure is to contribute to 'create an incentive to maintain current levels of production in the sectors or regions concerned' (cf. Article 52(5)). Its aim is not to restart production after an exit during the great Sugar Reform in $\mathbf{2 0 0 6}$ or to enhance production beyond current levels. So the legislation rules out any significant degree of sugar beet production expansion beyond current production (or non-production) 
levels. However, this clause is currently under discussion. At the time of writing this report, the EU Commission, Parliament and Council are discussing the so-called Omnibus-Regulation. This discussion might result in a compromise to have paragraph 5 of Article 52 of Regulation 1307/2013 deleted. If this clause will be deleted, it will provide MSs with further room for manoeuvre. In the latter case, MSs could implement coupled support with the aim to reinstall sugar beet production.

\subsection{VCS effects in 'weak' and stronger regions}

As has been shown in Table 3.1, all VCS-MSs applied this measure in a generic and country-wide way. They could do this because the defined area limits are in general not constraining even though the complete national sown area is supported (see Table 6.1, columns (2) and (3)). This means that under the current implementation no discrimination takes place between weak and strong regions within the VCS-MSs, but that all sugar beet growers in a MSs benefit in a similar way from the support. As can be deduced from this research a more differentiated implementation, better taking into account the regional heterogeneity, could have contributed to a better support for 'weak' regions. Currently the voluntary coupled support measure is applied in a not very targeted way. One could argue that this has led to an over-compensation of the strong regions and an under-compensation of the weak regions within VCS-MSs.

Aside from affecting the level playing field between MSs, VCS also affects the position of sugar beet in the crop mix farmers choose, with the competitive position of sugar beet strengthened relative to that of other crops such as wheat, barley, oilseeds, etc. These alternative crops may also receive coupled support, but will more likely often not receive such support.

\subsection{VCS application without adverse production and market effects}

As has been shown in Chapter 5, the VCS measure leads to adverse production effects. These originate from the induced expansion of EU sugar beet production by the coupled payments. This expansion generates a downward pressure on EU sugar beet prices. The decline in sugar beet prices due to the coupled support generates, as a secondary effect, a reduction in the supply of sugar beets (as farmers shift to other crops). This second order effect takes place in all sugar beet producing MSs. However, in VCS-MSs, there is also a positive first order effect (the coupled support leading to an increase in the sugar beet supply), which is in general dominating the negative second order effect (see the discussion of the simulation results discussed in the previous chapter).

Reducing the adverse effect generated by the coupled support would only be possible by reducing the first order production enhancement effects of the coupled support. This could be done for example by applying more strict area limits than are currently implemented (see Table 6.1, columns (2) and (3)).

\subsection{Differences between sugar beet and other crops?}

As has been shown in the introduction (Chapter 1), VCS is heavily applied in protein crops, the beef and veal, dairy, and sheep and goats sectors in the EU. An important difference between dairy farmers and arable farmers is that dairy farmers have hardly any alternative rather than producing milk (with some beef as a joint side product), whereas arable farmers have many alternatives in that they can and actually nearly always do grow more than one crop on their land. As regards dairy, this is a highly specialised type of production, with high fixed costs and production specific investments (asset specificity, sunk costs). As regards the beef sector, the picture is more mixed. A significant part of EU beef production takes place in marginal production areas, where farmers have not many alternatives to beef production, and might even abandon the land if the profitability of this activity declines. Aside from this, there are forms of specialised intensive beef (and veal) production systems where there 
might be some alternatives and/or there is less risk of land abandonment in case of reduced support. The revenue and even more the income dependence of beef producers from the direct payments including coupled support is in general much higher than in the sugar beet sector.

The sugar beet, milk and beef sectors all rely on processing of their products. For all three sectors, it holds that the capital intensity of this downstream stage of the supply chain (sugar beet processors, dairy manufacturers, slaughtering houses) is high and that the processing facilities have hardly any alternative use opportunities (asset specificity). Given the already mentioned alternatives arable farmers have, the sugar beet processing industry is likely to be more vulnerable to variability with respect to their sourcing of input (sugar beets) than the other two sectors (dairy, beef).

VCS may affect the functioning of the supply chain as a whole and can, when there is market power, lead to a shift of rents or profits along the chain partners. As such, even though VCS is paid to farmers, they are not necessarily the (only) ones that profit. Sugar beet processors may reduce the price they pay to farmers for sugar beets, since a lower compensation to farmers may already be sufficient to guarantee adequate sourcing of the processing sector. ${ }^{13}$

Dairy, beef and veal, sheep and goat, and sugar beet sectors are similar in that these activities can contribute, at least within certain bounds, to biodiversity and/or soil quality (see crop rotation and permanent grassland requirements in the EU's greening policy).

Summarising, the key difference between the sugar sector and other sectors with VCS is that arable farmers have more alternatives compared to dairy, beef and sheep farmers, which makes them less dependent on one specific activity.

\subsection{Concluding remarks}

Voluntary coupled support is a tricky instrument: on the one hand it can contribute to sustain production in regions where production is in decline or facing difficulties. As such, it has a social function and may also contribute to the stewardship function of agriculture. On the other hand voluntary coupled support, when unevenly applied, may hamper the idea of the single market and negatively affect a level playing field. The wording in the legislation suggests a targeted rather than a generic application of voluntary coupled support to sectors. However, the application of voluntary coupled support to sugar beet growing as well as to other sectors has generally been applied in a country-wide way, including all producers. This has been facilitated by the area ceilings granted to MSs, which are so generous that they allow for the inclusion of a MS's whole sugar beet production. As a result, MSs are not enforced to prioritise between producers who are more and less in need of this type of support. As such an evaluation of the implementation of VCS as it has been applied is needed to assess whether the instrument has been properly used so far and when this is questioned to come with proposals how to better apply the instrument.

\footnotetext{
${ }^{13}$ There may be a difference between private and cooperative processors. In the case that sugar beet growers are a member of a cooperative processor, they will probably receive a higher sugar beet price and/or payments for their membership shares. In case of private processors, they could exercise their market power, in case they have this, to attract part of the rents in the supply chain, implying that sugar beet growers may not benefit from the full amount of the VCS payment (due to receiving a lower price for sugar beets than would have been otherwise the case).
} 


\section{$7 \quad$ Conclusions and recommendations}

\subsection{Current situation}

The first research question was: Which data and facts are available about the sugar beet areas in the EU and the VCS support levels in the ten VCS-MSs? Chapter 3 provides data in tables and figures on sugar beet areas in the EU and the developments since 2015, specifically of the VCS-MSs and the 60 major sugar beet growing regions within these ten MSs. Also data on VCS amounts per MS involved are presented. Additional information is given on the number of sugar beet growers and the farm structure in the VCS-MSs. The analysis of these data led to the following conclusions:

- In most VCS-MSs, there is a relatively small sugar beet area per grower compared to the other sugar beet growing MSs and they have relatively low sugar beet yields per ha;

- Sugar beet growing is on average less profitable in the VCS-MSs and they benefit less from economies of scale compared to the rest of the EU;

- In the ten VCS-MSs analysed, 71,000 sugar beet growers were involved or $45 \%$ of the total number of growers in the EU. In 2015, they produced 24.5 million tonnes of sugar beet or $22 \%$ of the EUproduction;

- There are 60 regions in ten VCS-MSs with significant sugar beet areas. In these regions sugar beets are grown under very different climatic conditions, varying from dry and hot in Spain, Italy and Greece, partly compensated for with irrigation or growing winter beets (in Spain) to cold and rain fed (Finland and parts of Poland);

- In 2015, 4.1 billion (or 9\%) of the total direct payments in 2015 (45.4 billion euro) were paid as coupled support; for sugar beet this was only $0.4 \%$ of the annual amount. A share of $0.4 \%$ seems a relatively small figure, but an average VCS amount of 354 euro/ha is relatively high compared to the direct payments per ha.

\subsection{Production costs of sugar beet growing in VCS- and other MSs}

The second research question was: How high are the production costs of sugar beet growing in these countries and in the other sugar beet growing MSs? Standard Output data of sugar beet and alternative crops (cereals and rapeseed) were collected and analysed for the VCS-MSs and compared with a number of MSs without VCS, because no data about production costs in all VCS-MSs were available. This indicator appeared to be a good indicator to compare the competitiveness of sugar beet with other crops per MS and even per region within an MS. The following conclusions were drawn:

- In the VCS-MSs-VCS the SO of sugar beet is on average 1,950 euro/ha, which is more than 500 euro/ha lower than in the non-VCS-MSs. When the VCS is included in the payments per ha, on average 330 euro/ha, then the difference with the non-VCS-MSs is only 230 euro/ha. On average, sugar beet growing in the VCS-MSs can compete with sugar beet growing in the non-VCS-MSs.

- Sugar beet is a competitive crop in all VCS-MSs compared to cereals and rapeseed, even without a VCS premium. The only exception is Finland, where a relatively small VCS of 67 euro/ha plus an additional coupled premium for sugar beet growing of 350 euro/ha improved its competitiveness towards cereals and rapeseed.

\subsection{Effects of VCS support on sugar beet areas and the EU-sugar market}

The third research question was: Which effects does the VCS-support for sugar beet growing have on the sugar beet areas in the ten VCS-MSs and in the other sugar beet growing MSs without VCS- 
support, and on the EU sugar market? On average, as a result of the VCS, EU sugar beet production has been estimated to increase by about $1.3 \%$, which generates an induced price decline of about 4.5\%. Sugar beet growers in MSs that apply VCS in general benefit, because they receive a subsidy (VCS-premium) per tonne of sugar beet produced. However, sugar beet growers in MSs that do not apply the VCS instrument are negatively affected, because of the induced price decline. Aggregating all effects there is a net gain at EU-28 level for the sugar beet growers, which amounts about 83 million euro. MSs that apply VCS gain 215.9 million euro, whereas the MSs not applying VCS face a loss of 132.7 million euro. The simulated results provide an insight into the order of magnitude of the impacts of VCS on the EU sugar sector and their distribution over MSs, conditional on a number of assumptions that had to be made to be able to make the quantitative calculations.

\subsection{Legitimacy of national or regional VCS-support}

The fourth research question was: In how far is national or regional VCS support legitimate? Voluntary coupled support is an instrument which generates different impacts on EU policy objectives (chapter 6). On the one hand it can contribute to sustain production in regions where production is in decline or facing difficulties. As such, it has a social function and may also contribute to the stewardship function of agriculture. On the other hand voluntary coupled support, when unevenly applied, may hamper the idea of the single market and negatively affect a level playing field. The wording in the legislation suggests a targeted rather than a generic application of voluntary coupled support to sectors.

However, the application of voluntary coupled support to sugar beets, as well as to other sectors has generally been applied in a country-wide way, including all producers. This has been facilitated by the area ceilings granted to MSs, which are so generous that they allow for the inclusion of a MS's whole sugar beet production. As a result, MSs are not enforced to prioritise between producers who are more and less in need of this type of support. As such an evaluation of the implementation of VCS as it has been applied is needed to assess whether the instrument has been properly used so far and when this is questioned to come with proposals how to better apply the instrument. This advice is based on the following observations and reasoning:

- There is apparently no relationship between sugar beet yields and the amount of VCS per ha granted throughout the group of VCS-MSs;

- On average, the sugar beet prices were not significantly lower in the VCS-MSs than in the non-VCSMSs (34.2 and 36.0 euro/tonne).

- For the VCS-group as a total, the average income was significantly lower $(14,000$ euro) than in the other five MSs. However, these data probably do not give a complete picture of the income situation of the farms. But still if the total income situation would be structurally insufficient, there are serious doubts whether a coupled support measure is an appropriate instrument to solve the income problem.

\subsection{Recommendations}

Based on the foregoing analysis, three recommendations are made:

- The analysis of VCS as provided in this report on sugar beets is one of the first analyses on the market impact of VCS. As the analysis shows, the VCS instrument distorts the level playing field in sugar beet production. Although the theoretical basis for this is clear the empirical impact measurement faced difficulties as in the sugar beet sector a policy regime switch (quota abolition) has taken place, which obscures the measurement of the MS sugar beet supply curves and, as a consequence, the derived VCS impact on supply. A more refined analysis is needed to achieve a more robust assessment of the impact as well as its magnitude;

- Whereas this study shows the estimated impact of VCS in the EU sugar beet sector, VCS is also and sometimes to a greater extent applied in other sectors (e.g. beef, sheep, dairy), for which reason it is recommended to complement this analysis with similar analyses of other sectors;

- This study raises doubts about whether the application of VCS by MSs is in accordance with the spirit of the EU legislation even though it may fit according to its letter. Therefore, it is recommended to 
request a serious assessment of MSs when choosing to implement VCS, motivating their choice. Such a request would be in line with the recent Communication of the EU Commission with respect to the future of the CAP, which requests MSs to provide CAP strategic plans and emphasises its role to preserve a level playing field (EU Single Market). ${ }^{14}$ 


\section{References and websites}

Burrell, A., M. Himics, B. van Doorslaer, P. Ciaian, and S. Shrestha (2014). EU sugar policy: A sweet transition after 2015? Sevilla, European Commission, Joint Research Centre, Institute for Prospective Technological Studies.

Buysse, J., B. Fernagut, O. Harmignie, B. Henry de Frahan, L. Lauwers, P. Polomé, G. van Huylenbroeck, and J. van Meensel (2007). Farm-based modelling of the EU sugar reform: impact on Belgian sugar beet suppliers. European Review of Agricultural Economics 34: 21-52.

CEFS (2016). CEFS Sugar Statistics 2016. Brussels, Comité Européen des Fabricants de Sucre. http://www.comitesucre.org/site/statistics/cefs-sugar-statistics-2016/

DG Agri (2016). Communication to the Commission - 2016/2017, R 952/2006 Art 22 para 3.

DG Agri (2017). Voluntary Coupled Support (VCS) / Sugar beet, Civil Dialogue Group - Sugar\&Starch 15 Sept 2017, presentation.

EC (2015). Voluntary coupled support - Sectors mostly supported; Notification of decisions taken by Member States by 1 August 2014; Informative note, 30 July 2015, http://ec.europa.eu/agriculture/sites/agriculture/files/direct-support/directpayments/docs/voluntary-coupled-support-note_en.pdf

EP (2013). Regulation (EU) No 1308/2013 of the European Parliament and of the Council of 17 December 2013 establishing a common organisation of the markets in agricultural products and repealing Council Regulations (EEC) No 922/72, (EEC) No 234/79, (EC) No 1037/2001 and (EC) No 1234/2007.

Gardner, B.L. (1987). The economics of agricultural policies. New York, McGraw-Hill.

Gohin, A., and J.-C. Bureau (2006). Modelling the EU sugar supply to assess sectoral policy reforms. European Review of Agricultural Economics 33: 233-247.

Hanse, B., F. Tijink, O. Mußhoff, and B. Märländer (2010). Comparison of costs and yields of 'type top' and 'type average' growers in Dutch sugarbeet growing, Sugar Industry / Zuckerindustrie 135 (2010) No. 9, 550-560.

Harrington, D.H., and R. Dubman (2008). Equilibrium Displacement Mathematical Programming Model Methodology and a Model of the U.S. Agricultural Sector. Washington DC, USDA-ERS, Technical Bulletin Number 1918.

KWIN (2015). Kwantitatieve Informatie Akkerbouw en Vollegrondsgroenteteelt (Quantitative Information Arable farming and Field vegetable growing; In Dutch). Wageningen UR, PPO-publication 643.

Nolte, S., J. Buysse, and G. van Huylenbrouck (2012). Modelling the effects of an abolition of the EU sugar quota on internal prices, production and imports. European Review of Agricultural Economics 39 (1): 75-94.

Sumner, D.A., and M.K. Wohlgenant (1985). Effects of an Increase in the Federal Excise Tax on Cigarettes, American Journal of Agricultural Economics. Vol. 67(May): 235-242.

Sumner, D.A. (2005). Boxed In: Conflicts Between U.S. Farm Policies and WTO Obligations. Trade Policy Analysis No. 32, CATO Institute, Washington, DC.

Wohlgenant, M.K. (2011). Consumer Demand and Welfare in Equilibrium Displacement Models. In: Jayson L. Lusk, Jutta Roosen, and Jason F. Shogren (eds.) The Oxford Handbook of the Economics of Food Consumption and Policy. Oxford, OUP. 


\section{Appendix 1 Sugar beet areas in the EU in different MSs over time ${ }^{15}$}

The ten countries with VCS support for sugar beet growing are marked in grey

\begin{tabular}{|c|c|c|c|c|c|c|c|c|}
\hline \multirow{2}{*}{$\begin{array}{l}\text { Member State } \\
\text { EU }\end{array}$} & \multicolumn{6}{|c|}{ Sugar beet area $(* 1,000 \mathrm{ha})$ in the year: } & \multirow{2}{*}{$\begin{array}{l}\text { Share in } \\
\text { EU ( } \%) \\
\text { a) }\end{array}$} & \multirow{2}{*}{$\begin{array}{c}\text { Applicable } \\
\text { quantitative } \\
\text { limit (1,000 } \\
\text { ha) }\end{array}$} \\
\hline & 2005 & 2007 & 2010 & 2013 & 2015 & 2016 & & \\
\hline Austria & 44.4 & 44.2 & 44.8 & 50.3 & 45.4 & 43.6 & 3 & \\
\hline Belgium & 85.5 & 82.7 & 59.3 & 58.7 & 53.7 & 56.3 & 4 & \\
\hline Bulgaria & 1 & 1.4 & 0 & 0 & 0 & 0 & 0 & \\
\hline Croatia & 0 & 0 & 32.8 & 26.5 & 16.2 & n.a. b) & 0 & 23 \\
\hline Czech Republic & 65 & 54.1 & 56.4 & 62.9 & 53.6 & 61 & 4 & 62.4 \\
\hline Denmark & 47.4 & 39.3 & 39.1 & 38.7 & 24.8 & 32.7 & 2 & \\
\hline Finland & 31.3 & 16 & 14.6 & 12 & 12.5 & 11 & 1 & 14.8 \\
\hline France & 383 & 393 & 384 & 397 & 350 & 367 & 26 & \\
\hline Germany & 420 & 405 & 364 & 357 & 283 & 299 & 21 & \\
\hline Greece & 38.5 & 13.9 & 18.7 & 4.7 & 4.9 & 5.1 & 0 & 13.4 \\
\hline Hungary & 54.8 & 33.7 & 15.5 & 17.9 & 15 & 13.7 & 1 & 20.2 \\
\hline Ireland & 31 & 1.5 & 0.8 & 0.9 & 0 & 0 & 0 & \\
\hline Italy & 195 & 84.2 & 58.7 & 40.4 & 38.1 & 33.1 & 2 & 62.3 \\
\hline Latvia & 12.8 & 0.3 & 0 & 0 & 0 & 0 & 0 & \\
\hline Lithuania & 22 & 16.4 & 15.4 & 17.8 & 12.3 & 14.7 & 1 & \\
\hline Netherlands & 91.3 & 82 & 70.6 & 73.2 & 56.9 & 70.1 & 5 & \\
\hline Poland & 286 & 247 & 206 & 194 & 172 & 203 & 15 & 211.3 \\
\hline Portugal & 7.2 & 2.3 & 0.1 & 0.6 & 0.1 & 0.1 & 0 & \\
\hline Romania & 23.6 & 29.2 & 25.3 & 25.1 & 23.6 & 24 & 2 & 29.3 \\
\hline Slovakia & 32.7 & 18.9 & 17.9 & 20.3 & 21.7 & 22.1 & 2 & 20.4 \\
\hline Slovenia & 5 & 0 & 0 & 0 & 0 & 0 & 0 & \\
\hline Spain & 112 & 83.2 & 48.6 & 33.2 & 37 & 37 & 3 & 40.1 \\
\hline Sweden & 49.5 & 40.7 & 38 & 35.6 & 19 & 30 & 2 & \\
\hline United Kingdom & 148 & 125 & 119 & 117 & 74.2 & 70.8 & 5 & \\
\hline Total & 2,187 & 1,814 & 1,630 & 1,584 & 1,314 & 1,394 & 100 & \\
\hline Total VCS-MSs & 800.4 & 566.3 & 475.8 & 432.3 & 389.7 & 404.9 & 29 & 497.2 \\
\hline
\end{tabular}

a) In 2016;

b) not available.

Sources: Eurostat; DG Agri, 2016.

\footnotetext{
${ }^{15}$ Some EU member states have not grown sugar beet at all during this period of time and are left out of the table: Cyprus, Luxembourg, Estonia and Malta.
} 


\section{Appendix 2 Voluntary Coupled Support amounts for sugar beet for the MSs involved}

Sugar beet

\begin{tabular}{|c|c|c|c|c|c|c|c|c|c|c|c|c|c|c|}
\hline \multirow[t]{2}{*}{ MS } & \multirow[t]{2}{*}{ Measure } & \multirow{2}{*}{$\begin{array}{l}\text { Applicable } \\
\text { quantitative } \\
\text { limit (ha) }\end{array}$} & \multicolumn{6}{|c|}{ Amount of VCS support (euro per hectare) } & \multicolumn{6}{|c|}{ Total amount of VCS support (in million euro) } \\
\hline & & & 2015 & 2016 & 2017 & 2018 & 2019 & 2020 & 2015 & 2016 & 2017 & 2018 & 2019 & 2020 \\
\hline$E U-28$, tot & & 497,222 & 350 & 356 & 358 & 360 & 362 & 341 & 174.25 & 176.98 & 177.99 & 179.10 & 180.22 & 169.36 \\
\hline Poland & Payment for sugar beets & 211,340 & 384 & 386 & 388 & 390 & 392 & 348 & 81.20 & 81.60 & 82.00 & 82.46 & 82.93 & 73.58 \\
\hline $\begin{array}{l}\text { Czech } \\
\text { Rep. }\end{array}$ & Sugar beets & 62,400 & 267 & 267 & 267 & 267 & 267 & 267 & 16.67 & 16.67 & 16.67 & 16.67 & 16.67 & 16.67 \\
\hline Italy & Sugar beets & 62,266 & 276 & 273 & 269 & 266 & 262 & 262 & 17.21 & 16.99 & 16.76 & 16.55 & 16.34 & 16.34 \\
\hline \multirow[t]{3}{*}{ Spain } & Sugar beets, all & 40,100 & $311-445$ & $311-445$ & $311-445$ & $311-445$ & 311-445 & 311-445 & 16.84 & 16.84 & 16.84 & 16.84 & 16.84 & 16.84 \\
\hline & $\begin{array}{l}\text { Coupled support for sugar } \\
\text { beet (spring sown) }\end{array}$ & 32,500 & 445 & 445 & 445 & 445 & 445 & 445 & 14.47 & 14.47 & 14.47 & 14.47 & 14.47 & 14.47 \\
\hline & $\begin{array}{l}\text { Coupled support for sugar } \\
\text { beet (autumn sown) }\end{array}$ & 7,600 & 311 & 311 & 311 & 311 & 311 & 311 & 2.37 & 2.37 & 2.37 & 2.37 & 2.37 & 2.37 \\
\hline Romania & $\begin{array}{l}\text { Measure for coupled } \\
\text { support for sugar beets }\end{array}$ & 29,300 & 600 & 610 & 620 & 630 & 640 & 645 & 17.58 & 17.87 & 18.17 & 18.46 & 18.75 & 18.90 \\
\hline Croatia & $\begin{array}{l}\text { Coupled Support for } \\
\text { Sugar beet production }\end{array}$ & 23,000 & 121 & 133 & 159 & 184 & 209 & 201 & 2.78 & 3.07 & 3.65 & 4.23 & 4.81 & 4.63 \\
\hline Slovakia & $\begin{array}{l}\text { Coupled payment for } \\
\text { the cultivation of sugar } \\
\text { beet }\end{array}$ & 20,429 & 390 & 393 & 396 & 399 & 402 & 351 & 7.98 & 8.03 & 8.09 & 8.16 & 8.22 & 7.18 \\
\hline Hungary & $\begin{array}{l}\text { Coupled support for } \\
\text { sugar beet }\end{array}$ & 20,200 & 396 & 396 & 395 & 395 & 395 & 374 & 8.00 & 7.99 & 7.98 & 7.98 & 7.98 & 7.54 \\
\hline Finland & Sugar beet premium & 14,820 & 67 & 67 & 67 & 67 & 67 & 67 & 1.00 & 1.00 & 1.00 & 1.00 & 1.00 & 1.00 \\
\hline Greece & $\begin{array}{l}\text { Coupled Support for } \\
\text { Sugar beet production }\end{array}$ & 13,367 & 374 & 518 & 511 & 506 & 500 & 500 & 5.00 & 6.92 & 6.84 & 6.76 & 6.68 & 6.68 \\
\hline
\end{tabular}




\section{Appendix 3 Characteristics of the 60 most relevant regions in the ten VCS-MSs}

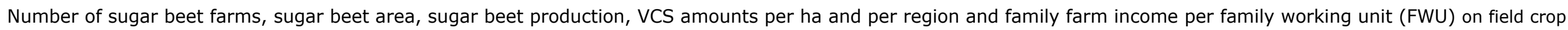
farms, with a ranking per MS involved.

\begin{tabular}{|c|c|c|c|c|c|c|c|c|c|c|}
\hline MS & Code & Region & $\begin{array}{l}\text { Number of } \\
\text { farmers }\end{array}$ & Area (ha) & $\begin{array}{l}\text { Production } \\
\text { (1,000 tonnes) }\end{array}$ & $\begin{array}{l}\text { VCS-support } \\
\text { (euro/ha) }\end{array}$ & $\begin{array}{l}\text { Total support } \\
\text { region } \\
\text { ( } 1,000 \text { euros) }\end{array}$ & $\begin{array}{l}\text { family farm } \\
\text { income/FWU } \\
\text { (euro) }\end{array}$ & $\begin{array}{l}\text { national/regional } \\
\text { data }\end{array}$ & $\begin{array}{l}\text { Production per } \\
\text { ha (tonnes) }\end{array}$ \\
\hline Croatia & HRO4 & Kontinentalna Hrvatska & 870 & 20,250 & 1,051 & 121 & 2,450 & 5,555 & regional & 51.9 \\
\hline $\begin{array}{l}\text { Czech } \\
\text { Republic }\end{array}$ & CZO2 & Strední Cechy & 260 & 17,450 & 1,056 & 267 & 4,659 & 24,224 & national & 60.5 \\
\hline $\begin{array}{l}\text { Czech } \\
\text { Republic }\end{array}$ & CZ04 & Severozápad & 30 & 2,660 & 158 & 267 & 710 & 24,224 & national & 59.4 \\
\hline $\begin{array}{l}\text { Czech } \\
\text { Republic }\end{array}$ & CZ05 & Severovýchod & 270 & 16,460 & 985 & 267 & 4,395 & 24,224 & national & 59.8 \\
\hline $\begin{array}{l}\text { Czech } \\
\text { Republic }\end{array}$ & CZ06 & Jihovýchod & 70 & 5,680 & 324 & 267 & 1,517 & 24,224 & national & 57.0 \\
\hline $\begin{array}{l}\text { Czech } \\
\text { Republic }\end{array}$ & CZ07 & Strední Morava & 180 & 13,660 & 840 & 267 & 3,647 & 24,224 & national & 61.5 \\
\hline $\begin{array}{l}\text { Czech } \\
\text { Republic }\end{array}$ & CZ08 & Moravskoslezsko & 90 & 6,650 & 390 & 267 & 1,776 & 24,224 & national & 58.7 \\
\hline Finland & FI19 & Länsi-Suomi & 310 & 5,210 & 185 & 67 & 349 & 14,169 & national & 35.6 \\
\hline Finland & FI1B & Helsinki-Uusimaa & 20 & 320 & 0 & 67 & 21 & 14,169 & national & 0.0 \\
\hline Finland & FI1C & Etelä-Suomi & 430 & 6,400 & 262 & 67 & 429 & 16,795 & regional & 41.0 \\
\hline Greece & EL11 & Anatoliki Makedonia, Thraki (NUTS 2010) & 360 & 860 & 51 & 374 & 322 & 11,788 & national & 59.5 \\
\hline Greece & EL12 & Kentriki Makedonia (NUTS 2010) & 740 & 2,200 & 129 & 374 & 823 & 11,788 & national & 58.8 \\
\hline Greece & EL13 & Dytiki Makedonia (NUTS 2010) & 100 & 620 & 35 & 374 & 232 & 11,788 & national & 56.1 \\
\hline Greece & EL14 & Thessalia (NUTS 2010) & 270 & 960 & 62 & 374 & 359 & 15,041 & regional & 64.7 \\
\hline
\end{tabular}




\begin{tabular}{|c|c|c|c|c|c|c|c|c|c|c|}
\hline MS & Code & Region & $\begin{array}{l}\text { Number of } \\
\text { farmers }\end{array}$ & Area (ha) & $\begin{array}{l}\text { Production } \\
\text { (1,000 tonnes) }\end{array}$ & $\begin{array}{l}\text { VCS-support } \\
\text { (euro/ha) }\end{array}$ & $\begin{array}{l}\text { Total support } \\
\text { region } \\
\text { ( } 1,000 \text { euros) }\end{array}$ & $\begin{array}{l}\text { family farm } \\
\text { income/FWU } \\
\text { (euro) }\end{array}$ & $\begin{array}{l}\text { national/regional } \\
\text { data }\end{array}$ & $\begin{array}{l}\text { Production per } \\
\text { ha (tonnes) }\end{array}$ \\
\hline Hungary & HU10 & Közép-Magyarország & 80 & 420 & 26 & 396 & 166 & 30,597 & national & 61.0 \\
\hline Hungary & HU21 & Közép-Dunántúl & 90 & 3,920 & 216 & 396 & 1,552 & 30,597 & national & 55.1 \\
\hline Hungary & HU22 & Nyugat-Dunántúl & 180 & 1,700 & 84 & 396 & 673 & 30,597 & national & 49.7 \\
\hline Hungary & HU23 & Dél-Dunántúl & 190 & 5,860 & 313 & 396 & 2,321 & 30,597 & national & 53.4 \\
\hline Hungary & HU31 & Észak-Magyarország & 60 & 190 & 11 & 396 & 75 & 34,907 & regional & 57.6 \\
\hline Hungary & HU32 & Észak-Alföld & 220 & 2,770 & 143 & 396 & 1,097 & 30,597 & national & 51.7 \\
\hline Hungary & HU33 & Dél-Alföld & 140 & 3,030 & 150 & 396 & 1,200 & 30,597 & national & 49.6 \\
\hline Italy & ITC1 & Piemonte & 300 & 1,940 & 48 & 276 & 535 & 21,642 & regional & 24.9 \\
\hline Italy & ITC4 & Lombardia & 360 & 2,220 & 31 & 276 & 613 & 19,829 & regional & 14.0 \\
\hline Italy & ITH3 & Veneto & 1680 & 9,470 & 66 & 276 & 2,614 & 25,696 & regional & 7.0 \\
\hline Italy & ITH4 & Friuli-Venezia Giulia & 20 & 240 & 0 & 276 & 66 & 14,944 & regional & 0.0 \\
\hline Italy & ITH5 & Emilia-Romagna & 2170 & 20,340 & 534 & 276 & 5,614 & 28,241 & regional & 26.3 \\
\hline Italy & ITI1 & Toscana & 40 & 160 & 0 & 276 & 44 & 13,267 & regional & 17.0 \\
\hline Italy & ITI3 & Marche & 140 & 560 & 0 & 276 & 155 & 14,077 & regional & 24.0 \\
\hline Italy & ITI4 & Lazio & 40 & 380 & 0 & 276 & 105 & 18,234 & regional & 22.0 \\
\hline Italy & ITF2 & Molise & 20 & 170 & 0 & 276 & 47 & 16,167 & regional & 0.0 \\
\hline Italy & ITF4 & Puglia & 250 & 4,700 & 94 & 276 & 1,297 & 34,340 & regional & 20.0 \\
\hline Poland & PL11 & Lódzkie & 2080 & 5,850 & 304 & 384 & 2,246 & 6,773 & national & 51.9 \\
\hline Poland & PL12 & Mazowieckie & 2570 & 9,800 & 601 & 384 & 3,763 & 6,773 & national & 61.4 \\
\hline Poland & PL21 & Malopolskie & 500 & 1,350 & 63 & 384 & 518 & 6,773 & national & 46.4 \\
\hline Poland & PL22 & Slaskie & 730 & 1,790 & 98 & 384 & 687 & 6,773 & national & 54.7 \\
\hline Poland & PL31 & Lubelskie & 9370 & 33,150 & 1,854 & 384 & 12,730 & 6,773 & national & 55.9 \\
\hline Poland & PL32 & Podkarpackie & 1220 & 3,760 & 210 & 384 & 1,444 & 6,773 & national & 56.0 \\
\hline Poland & PL33 & Swietokrzyskie & 1490 & 4,420 & 233 & 384 & 1,697 & 6,773 & national & 52.8 \\
\hline Poland & PL41 & Wielkopolskie & 8440 & 41,400 & 2,444 & 384 & 15,898 & 6,773 & national & 59.0 \\
\hline Poland & PL42 & Zachodniopomorskie & 750 & 9,430 & 596 & 384 & 3,621 & 6,773 & national & 63.2 \\
\hline Poland & PL43 & Lubuskie & 130 & 1,090 & 69 & 384 & 419 & 6,773 & national & 63.2 \\
\hline Poland & PL51 & Dolnoslaskie & 2310 & 17,250 & 951 & 384 & 6,624 & 6,773 & national & 55.1 \\
\hline Poland & PL52 & Opolskie & 2070 & 14,310 & 797 & 384 & 5,495 & 6,773 & national & 55.7 \\
\hline Poland & PL61 & Kujawsko-Pomorskie & 8030 & 37,080 & 2,239 & 384 & 14,239 & 6,773 & national & 60.4 \\
\hline Poland & PL62 & Warminsko-Mazurskie & 130 & 2,770 & 175 & 384 & 1,064 & 6,773 & national & 63.1 \\
\hline Poland & PL63 & Pomorskie & 1270 & 10,220 & 592 & 384 & 3,924 & 6,773 & national & 58.0 \\
\hline
\end{tabular}




\begin{tabular}{|c|c|c|c|c|c|c|c|c|c|c|}
\hline MS & Code & Region & $\begin{array}{l}\text { Number of } \\
\text { farmers }\end{array}$ & Area (ha) & $\begin{array}{l}\text { Production } \\
\text { ( } 1,000 \text { tonnes) }\end{array}$ & $\begin{array}{l}\text { VCS-support } \\
\text { (euro/ha) }\end{array}$ & $\begin{array}{l}\text { Total support } \\
\text { region } \\
\text { ( } 1,000 \text { euros) }\end{array}$ & $\begin{array}{l}\text { family farm } \\
\text { income/FWU } \\
\text { (euro) }\end{array}$ & $\begin{array}{l}\text { national/regional } \\
\text { data }\end{array}$ & $\begin{array}{l}\text { Production per } \\
\text { ha (tonnes) }\end{array}$ \\
\hline Romania & RO11 & Nord-Vest & 650 & 3,680 & 131 & 600 & 2,208 & 4,574 & regional & 35.6 \\
\hline Romania & RO12 & Centru & 1780 & 7,560 & 297 & 600 & 4,536 & 5,501 & regional & 39.3 \\
\hline Romania & $\mathrm{RO} 21$ & Nord-Est & 9990 & 10,370 & 0 & 600 & 6,222 & 4,989 & regional & 34.0 \\
\hline Romania & $\mathrm{RO} 22$ & Sud-Est & 50 & 770 & 30 & 600 & 462 & 14,707 & regional & 38.6 \\
\hline Romania & RO31 & Sud - Muntenia & 940 & 50 & 0 & 600 & 30 & 5,298 & regional & 0.0 \\
\hline Romania & RO41 & Sud-Vest Oltenia & 100 & 10 & 0 & 600 & 6 & 5,271 & regional & 0.0 \\
\hline Romania & $\mathrm{RO} 42$ & Vest & 220 & 2,610 & 89 & 600 & 1,566 & 13,510 & regional & 34.1 \\
\hline Slovakia & SK01 & Bratislavský kraj & 10 & 1,380 & 89 & 390 & 538 & 13,855 & national & 64.2 \\
\hline Slovakia & SK02 & Západné Slovensko & 180 & 18,840 & 1,053 & 390 & 7,348 & 13,855 & national & 55.9 \\
\hline Spain & ES11 & Galicia & 90 & 10 & 0 & 420 & 4 & 20,316 & regional & 0.0 \\
\hline Spain & ES21 & País Vasco & 170 & 2,090 & 153 & 420 & 877 & 20,813 & regional & 73.0 \\
\hline Spain & ES23 & La Rioja & 140 & 1,150 & 105 & 420 & 483 & 21,131 & regional & 91.5 \\
\hline Spain & ES41 & Castilla y León & 4420 & 25,290 & 2,029 & 420 & 10,612 & 12,354 & regional & 80.2 \\
\hline Spain & ES61 & Andalucía & 670 & 4,600 & 324 & 420 & 1,930 & 42,512 & regional & 70.4 \\
\hline Total & & 60 regions & 70,209 & 409,190 & 22,771 & & 151,053 & & & \\
\hline
\end{tabular}




\section{Appendix 4 Distribution of sugar beet areas per farm in the VCS- MSs (in 2013)}

\begin{tabular}{|c|c|c|c|c|c|c|c|c|c|}
\hline \multirow[t]{2}{*}{ MS } & \multicolumn{9}{|c|}{ Number of farms with .. ha of sugar beet } \\
\hline & $<2$ & $2-4.9$ & $5-9.9$ & $10-19.9$ & $20-29.9$ & $30-49.9$ & $50-99.9$ & $>100$ & Total \\
\hline Croatia & 0 & 10 & 30 & 110 & 100 & 180 & 260 & 190 & 880 \\
\hline Czech Republic & 30 & 30 & 0 & 20 & 20 & 50 & 140 & 620 & 920 \\
\hline Finland & 0 & 0 & 20 & 50 & 80 & 190 & 250 & 160 & 760 \\
\hline Greece & 0 & 310 & 310 & 370 & 220 & 200 & 60 & 20 & 1,470 \\
\hline Hungary & 400 & 70 & 40 & 50 & 40 & 30 & 60 & 260 & 960 \\
\hline Italy & 70 & 590 & 660 & 1,030 & 800 & 640 & 800 & 490 & 5,090 \\
\hline Poland & 1,010 & 1,950 & 5,800 & 14,200 & 7,310 & 5,870 & 3,310 & 1,630 & 41,090 \\
\hline Romania & 6,770 & 4,710 & 1,140 & 420 & 150 & 120 & 110 & 320 & 13,730 \\
\hline Slovakia & 0 & 0 & 0 & 0 & 0 & 0 & 10 & 180 & 190 \\
\hline Spain & 210 & 330 & 280 & 360 & 480 & 1,070 & 1,450 & 1,350 & 5,520 \\
\hline Total VCS-MSs & 8,490 & 8,000 & 8,280 & 16,610 & 9,200 & 8,350 & 6,450 & 5,220 & 70,610 \\
\hline Total EU & 8,670 & 8,560 & 10,180 & 22,240 & 15,780 & 22,230 & 31,210 & 37,770 & 156,670 \\
\hline
\end{tabular}

Source: Eurostat, adapted by Wageningen Economic Research.

\begin{tabular}{|c|c|c|c|c|c|c|c|c|c|}
\hline \multirow[t]{2}{*}{ MS } & \multicolumn{9}{|c|}{ Number of farms with .. ha of sugar beet ( $\%)$} \\
\hline & $<2$ & $2-4.9$ & $5-9.9$ & $10-19.9$ & $20-29.9$ & $30-49.9$ & $50-99.9$ & $>100$ & Total \\
\hline Croatia & 0 & 1 & 3 & 13 & 11 & 20 & 30 & 22 & 100 \\
\hline Czech Republic & 3 & 3 & 0 & 2 & 2 & 5 & 15 & 67 & 100 \\
\hline Finland & 0 & 0 & 3 & 7 & 11 & 25 & 33 & 21 & 100 \\
\hline Greece & 0 & 21 & 21 & 25 & 15 & 14 & 4 & 1 & 100 \\
\hline Hungary & 42 & 7 & 4 & 5 & 4 & 3 & 6 & 27 & 100 \\
\hline Italy & 1 & 12 & 13 & 20 & 16 & 13 & 16 & 10 & 100 \\
\hline Poland & 2 & 5 & 14 & 35 & 18 & 14 & 8 & 4 & 100 \\
\hline Romania & 49 & 34 & 8 & 3 & 1 & 1 & 1 & 2 & 100 \\
\hline Slovakia & 0 & 0 & 0 & 0 & 0 & 0 & 5 & 95 & 100 \\
\hline Spain & 4 & 6 & 5 & 7 & 9 & 19 & 26 & 24 & 100 \\
\hline Total VCS-MSs & 12 & 11 & 12 & 24 & 13 & 12 & 9 & 7 & 100 \\
\hline Total EU & 6 & 5 & 6 & 14 & 10 & 14 & 20 & 24 & 100 \\
\hline
\end{tabular}




\section{Appendix 5 Distribution of sugar beet areas over area categories in the VCS-MSs (in 2013)}

\begin{tabular}{|c|c|c|c|c|c|c|c|c|c|}
\hline \multirow[t]{2}{*}{ MS } & \multicolumn{9}{|c|}{ Area of sugar beets on farms with .. ha of sugar beet ( 1,000 ha) } \\
\hline & $<2$ & 2-4.9 & 5-9.9 & $10-19.9$ & $20-29.9$ & $30-49.9$ & $50-99.9$ & $>100$ & Total \\
\hline Croatia & 0 & 0 & 80 & 780 & 640 & 1,440 & 3,500 & 13,810 & 20,250 \\
\hline Czech Republic & 0 & 10 & 0 & 120 & 130 & 290 & 2,410 & 59,940 & 62,890 \\
\hline Finland & 0 & 0 & 80 & 360 & 780 & 2,300 & 3,940 & 4,510 & 11,970 \\
\hline Greece & 0 & 400 & 510 & 1,000 & 870 & 1,200 & 510 & 180 & 4,660 \\
\hline Hungary & 50 & 60 & 100 & 340 & 170 & 330 & 750 & 16,090 & 17,900 \\
\hline Italy & 50 & 1,410 & 1,460 & 3,380 & 4,690 & 6,370 & 9,440 & 13,640 & 40,440 \\
\hline Poland & 590 & 1,840 & 8,680 & 35,070 & 25,990 & 30,200 & 27,940 & 63,360 & 193,670 \\
\hline Romania & 500 & 580 & 500 & 450 & 450 & 720 & 1,370 & 20,480 & 25,050 \\
\hline Slovakia & 0 & 0 & 0 & 0 & 0 & 0 & 190 & 20,030 & 20,310 \\
\hline Spain & 170 & 460 & 350 & 920 & 1,630 & 4,000 & 9,700 & 16,010 & 33,230 \\
\hline Total VCS-MSs & 1,360 & 4,760 & 11,760 & 42,420 & 35,350 & 46,850 & 59,750 & 228,050 & 430,370 \\
\hline Total EU & 1,450 & 5,440 & 15,840 & 59,360 & 62,840 & 126,530 & 285,280 & $1,031,970$ & $1,588,780$ \\
\hline
\end{tabular}

\begin{tabular}{|c|c|c|c|c|c|c|c|c|c|}
\hline \multirow[t]{2}{*}{ MS } & \multicolumn{9}{|c|}{ Area of sugar beets on farms with .. ha of sugar beet ( $\%)$} \\
\hline & $<2$ & 2-4.9 & $5-9.9$ & $10-19.9$ & $20-29.9$ & $30-49.9$ & $50-99.9$ & $>100$ & Total \\
\hline Croatia & 0 & 0 & 0 & 4 & 3 & 7 & 17 & 68 & 100 \\
\hline Czech Republic & 0 & 0 & 0 & 0 & 0 & 0 & 4 & 95 & 100 \\
\hline Finland & 0 & 0 & 1 & 3 & 7 & 19 & 33 & 38 & 100 \\
\hline Greece & 0 & 9 & 11 & 21 & 19 & 26 & 11 & 4 & 100 \\
\hline Hungary & 0 & 0 & 1 & 2 & 1 & 2 & 4 & 90 & 100 \\
\hline Italy & 0 & 3 & 4 & 8 & 12 & 16 & 23 & 34 & 100 \\
\hline Poland & 0 & 1 & 4 & 18 & 13 & 16 & 14 & 33 & 100 \\
\hline Romania & 2 & 2 & 2 & 2 & 2 & 3 & 5 & 82 & 100 \\
\hline Slovakia & 0 & 0 & 0 & 0 & 0 & 0 & 1 & 99 & 100 \\
\hline Spain & 1 & 1 & 1 & 3 & 5 & 12 & 29 & 48 & 100 \\
\hline Total VCS-MSs & 0 & 1 & 3 & 10 & 8 & 11 & 14 & 53 & 100 \\
\hline Total EU & 0 & 0 & 1 & 4 & 4 & 8 & 18 & 65 & 100 \\
\hline
\end{tabular}




\section{Appendix 6 Sugar beet areas in the VCS- MSs and in the regions in these MSs with the largest area in 2013}

\begin{tabular}{|c|c|c|c|c|}
\hline \multirow[t]{2}{*}{ MS } & \multirow[t]{2}{*}{ Region } & \multicolumn{2}{|c|}{ Area of sugar beets (ha) in: } & \multirow{2}{*}{$\begin{array}{r}\text { Share in MS (\%) } \\
\text { a) }\end{array}$} \\
\hline & & MS & Region & \\
\hline Croatia & Total & 20,250 & & 100 \\
\hline Croatia & Kontinentalna Hrvatska & & 20,250 & 100 \\
\hline Czech Republic & Total & 62,890 & & 100 \\
\hline Czech Republic & Strední Cechy & & 17,450 & 28 \\
\hline Czech Republic & Severovýchod & & 16,460 & 26 \\
\hline Czech Republic & Strední Morava & & 13,660 & 22 \\
\hline Czech Republic & Moravskoslezsko & & 6,650 & 11 \\
\hline Finland & Total & 11,970 & & 100 \\
\hline Finland & Etelä-Suomi & & 6,400 & 53 \\
\hline Finland & Länsi-Suomi & & 5,210 & 44 \\
\hline Finland & Helsinki-Uusimaa & & 320 & 3 \\
\hline Greece & Total & 4,660 & & 100 \\
\hline Greece & Kentriki Makedonia & & 2,200 & 47 \\
\hline Greece & Thessalia & & 960 & 21 \\
\hline Greece & Anatoliki Makedonia, Thraki & & 860 & 18 \\
\hline Greece & Dytiki Makedonia & & 620 & 13 \\
\hline Hungary & Total & 17,900 & & 87 \\
\hline Hungary & Dél-Dunántúl & & 5,860 & 33 \\
\hline Hungary & Közép-Dunántúl & & 3,920 & 22 \\
\hline Hungary & Dél-Alföld & & 3,030 & 17 \\
\hline Hungary & Észak-Alföld & & 2,770 & 15 \\
\hline Italy & Total & 40,440 & & 91 \\
\hline Italy & Emilia-Romagna & & 20,340 & 50 \\
\hline Italy & Veneto & & 9,470 & 23 \\
\hline Italy & Puglia & & 4,700 & 12 \\
\hline Italy & Lombardia & & 2,220 & 5 \\
\hline Poland & Total & 193,670 & & 67 \\
\hline Poland & Wielkopolskie & & 41,400 & 21 \\
\hline Poland & Kujawsko-Pomorskie & & 37,080 & 19 \\
\hline Poland & Lubelskie & & 33,150 & 17 \\
\hline Poland & Dolnoslaskie & & 17,250 & 9 \\
\hline Romania & Total & 25,050 & & 97 \\
\hline Romania & Nord-Est & & 10,370 & 41 \\
\hline Romania & Centru & & 7,560 & 30 \\
\hline Romania & Nord-Vest & & 3,680 & 15 \\
\hline Romania & Vest & & 2,610 & 10 \\
\hline Slovakia & Total & 20,310 & & 100 \\
\hline Slovakia & Západné Slovensko & & 18,840 & 93 \\
\hline Slovakia & Bratislavský kraj & & 1,380 & 7 \\
\hline Spain & Total & 33,230 & & 100 \\
\hline Spain & Castilla y León & & 25,290 & 76 \\
\hline Spain & Andalucía & & 4,600 & 14 \\
\hline Spain & País Vasco & & 2,090 & 6 \\
\hline Spain & La Rioja & & 1,150 & 3 \\
\hline Total VCS-MSs & Largest of (maximum) four regions & 430,370 & 340,150 & 79 \\
\hline
\end{tabular}

a) The value per MS indicates the total share of the sugar beet area of the regions presented for that specific MS;

Source: Eurostat, adapted by Wageningen Economic Research. 


\section{Appendix 7 Sugar beet area distribution in the regions in the VCS-MSs with the largest area in 2013}

\begin{tabular}{|c|c|c|c|c|c|c|c|c|c|c|}
\hline \multirow[t]{3}{*}{ MS } & \multirow[t]{3}{*}{ Region } & \multicolumn{9}{|c|}{ Area of sugar beets on farms with .. ha of sugar beet (ha) } \\
\hline & & $<2$ & $2-4.9$ & $5-9.9$ & $10-$ & 20- & 30- & $50-$ & $>100$ & Total \\
\hline & & & & & 19.9 & 29.9 & 49.9 & 99.9 & & \\
\hline Croatia & Kontinentalna Hrvatska & 0 & 0 & 80 & 780 & 640 & 1,440 & 3,500 & 13,810 & 20,250 \\
\hline Croatia & Jadranska Hrvatska & $\mathrm{n} / \mathrm{a}$ & $\mathrm{n} / \mathrm{a}$ & $\mathrm{n} / \mathrm{a}$ & $\mathrm{n} / \mathrm{a}$ & $\mathrm{n} / \mathrm{a}$ & $\mathrm{n} / \mathrm{a}$ & $\mathrm{n} / \mathrm{a}$ & $\mathrm{n} / \mathrm{a}$ & $\mathrm{n} / \mathrm{a}$ \\
\hline Czech Republic & Strední Cechy & 0 & 0 & 0 & 30 & 0 & 160 & 620 & 16,650 & 17,450 \\
\hline Czech Republic & Severovýchod & 0 & 0 & 0 & 0 & 0 & 0 & 1,100 & 15,310 & 16,460 \\
\hline Czech Republic & Strední Morava & 0 & 10 & 0 & 90 & 130 & 0 & 330 & 13,100 & 13,660 \\
\hline Czech Republic & Moravskoslezsko & 0 & 0 & 0 & 0 & 0 & 50 & 230 & 6,360 & 6,650 \\
\hline Finland & Etelä-Suomi & 0 & 0 & 0 & 200 & 430 & 1,290 & 1,980 & 2,470 & 6,400 \\
\hline Finland & Länsi-Suomi & 0 & 0 & 50 & 160 & 340 & 960 & 1,850 & 1,830 & 5,210 \\
\hline Finland & Helsinki-Uusimaa & 0 & 0 & 0 & 0 & 0 & 0 & 110 & 170 & 320 \\
\hline Finland & Itä-Suomi & $\mathrm{n} / \mathrm{a}$ & $\mathrm{n} / \mathrm{a}$ & $\mathrm{n} / \mathrm{a}$ & $\mathrm{n} / \mathrm{a}$ & $\mathrm{n} / \mathrm{a}$ & $\mathrm{n} / \mathrm{a}$ & $\mathrm{n} / \mathrm{a}$ & $\mathrm{n} / \mathrm{a}$ & $\mathrm{n} / \mathrm{a}$ \\
\hline Greece & Kentriki Makedonia & 0 & 170 & 270 & 500 & 300 & 720 & 150 & 0 & 2,200 \\
\hline Greece & Thessalia & 0 & 80 & 120 & 300 & 250 & 150 & 40 & 0 & 960 \\
\hline Greece & Anatoliki Makedonia, Thraki & 0 & 130 & 110 & 160 & 260 & 120 & 70 & 0 & 860 \\
\hline Greece & Dytiki Makedonia & 0 & 10 & 0 & 30 & 50 & 220 & 240 & 70 & 620 \\
\hline Hungary & Dél-Dunántúl & 10 & 10 & 0 & 130 & 0 & 40 & 340 & 5,260 & 5,860 \\
\hline Hungary & Közép-Dunántúl & 0 & 0 & 0 & 0 & 0 & 0 & 50 & 3,860 & 3,920 \\
\hline Hungary & Dél-Alföld & 10 & 20 & 0 & 60 & 30 & 0 & 0 & 2,840 & 3,030 \\
\hline Hungary & Észak-Alföld & 10 & 20 & 50 & 90 & 70 & 240 & 150 & 2,150 & 2,770 \\
\hline Italy & Emilia-Romagna & 40 & 260 & 1,040 & 1,060 & 2,840 & 2,480 & 4,320 & 8,290 & 20,340 \\
\hline Italy & Veneto & 0 & 810 & 320 & 1,700 & 930 & 1,040 & 1,180 & 3,510 & 9,470 \\
\hline Italy & Puglia & 0 & 0 & 0 & 40 & 110 & 2,220 & 1,840 & 500 & 4,700 \\
\hline Italy & Lombardia & 0 & 0 & 0 & 290 & 190 & 500 & 730 & 520 & 2,220 \\
\hline Poland & Wielkopolskie & 30 & 140 & 1,870 & 8,410 & 5,770 & 5,630 & 4,950 & 14,590 & 41,400 \\
\hline Poland & Kujawsko-Pomorskie & 30 & 170 & 1,100 & 7,180 & 6,300 & 7,950 & 6,350 & 7,990 & 37,080 \\
\hline Poland & Lubelskie & 210 & 610 & 2,920 & 8,740 & 5,460 & 6,350 & 4,770 & 4,110 & 33,150 \\
\hline Poland & Dolnoslaskie & 0 & 130 & 470 & 1,690 & 1,210 & 1,750 & 2,380 & 9,620 & 17,250 \\
\hline Romania & Nord-Est & 330 & 330 & 90 & 50 & 10 & 10 & 210 & 9,330 & 10,370 \\
\hline Romania & Centru & 100 & 180 & 350 & 360 & 420 & 650 & 980 & 4,520 & 7,560 \\
\hline Romania & Nord-Vest & 20 & 30 & 60 & 20 & 10 & 0 & 40 & 3,480 & 3,680 \\
\hline Romania & Vest & 10 & 20 & 0 & 0 & 0 & 0 & 0 & 2,440 & 2,610 \\
\hline Slovakia & Západné Slovensko & 0 & 0 & 0 & 0 & 0 & 0 & 130 & 18,620 & 18,840 \\
\hline Slovakia & Bratislavský kraj & 0 & 0 & 0 & 0 & 0 & 0 & 0 & 1,380 & 1,380 \\
\hline Slovakia & Stredné Slovensko & $\mathrm{n} / \mathrm{a}$ & $\mathrm{n} / \mathrm{a}$ & $\mathrm{n} / \mathrm{a}$ & $\mathrm{n} / \mathrm{a}$ & $\mathrm{n} / \mathrm{a}$ & $\mathrm{n} / \mathrm{a}$ & $\mathrm{n} / \mathrm{a}$ & $\mathrm{n} / \mathrm{a}$ & $\mathrm{n} / \mathrm{a}$ \\
\hline Spain & Castilla y León & 160 & 360 & 350 & 370 & 1,310 & 2,730 & 7,770 & 12,250 & 25,290 \\
\hline Spain & Andalucía & 0 & 100 & 0 & 430 & 250 & 650 & 830 & 2,330 & 4,600 \\
\hline Spain & País Vasco & 0 & 0 & 0 & 0 & 0 & 360 & 650 & 1,060 & 2,090 \\
\hline Spain & La Rioja & 0 & 0 & 0 & 80 & 50 & 240 & 450 & 330 & 1,150 \\
\hline Total VCS- MSs & $\begin{array}{l}\text { Largest of (maximum) four } \\
\text { regions a) }\end{array}$ & 1,0 & 3,6 & 9,3 & 33,0 & 27,4 & 38,0 & 48,3 & 188,8 & 349,8 \\
\hline Total EU-28 & & 1,5 & 5,4 & 15,8 & 59,4 & 62,8 & 126,5 & 285,3 & $1,032,0$ & $1,588,8$ \\
\hline
\end{tabular}

a) 1,000 ha

Source: Eurostat, adapted by Wageningen Economic Research. 
Relative sugar beet area distribution in the regions in the VCS-MSs with the largest area in 2013

\begin{tabular}{|c|c|c|c|c|c|c|c|c|c|c|}
\hline \multirow[t]{3}{*}{ MS } & \multirow[t]{3}{*}{ Region } & \multicolumn{9}{|c|}{ Area of sugar beets on farms with .. ha of sugar beet ( $\%)$} \\
\hline & & $<2$ & 2-4.9 & 5-9.9 & & & & & $>100$ & Total \\
\hline & & & & & 19.9 & 29.9 & 49.9 & 99.9 & & \\
\hline Croatia & Jadranska Hrvatska & $\mathrm{n} / \mathrm{a}$ & $\mathrm{n} / \mathrm{a}$ & $\mathrm{n} / \mathrm{a}$ & $\mathrm{n} / \mathrm{a}$ & $\mathrm{n} / \mathrm{a}$ & $\mathrm{n} / \mathrm{a}$ & $\mathrm{n} / \mathrm{a}$ & $\mathrm{n} / \mathrm{a}$ & $\mathrm{n} / \mathrm{a}$ \\
\hline Czech Republic & Strední Cechy & 0 & 0 & 0 & 0 & 0 & 1 & 4 & 95 & 100 \\
\hline Czech Republic & Strední Morava & 0 & 0 & 0 & 1 & 1 & 0 & 2 & 96 & 100 \\
\hline Czech Republic & Moravskoslezsko & 0 & 0 & 0 & 0 & 0 & 1 & 3 & 96 & 100 \\
\hline Finland & Etelä-Suomi & 0 & 0 & 0 & 3 & 7 & 20 & 31 & 39 & 100 \\
\hline Finland & Länsi-Suomi & 0 & 0 & 1 & 3 & 7 & 18 & 36 & 35 & 100 \\
\hline Greece & Thessalia & 0 & 8 & 13 & 31 & 26 & 16 & 4 & 0 & 100 \\
\hline Greece & Anatoliki Makedonia, Thraki & 0 & 15 & 13 & 19 & 30 & 14 & 8 & 0 & 100 \\
\hline Greece & Dytiki Makedonia & 0 & 2 & 0 & 5 & 8 & 35 & 39 & 11 & 100 \\
\hline Hungary & Dél-Dunántúl & 0 & 0 & 0 & 2 & 0 & 1 & 6 & 90 & 100 \\
\hline Hungary & Közép-Dunántúl & 0 & 0 & 0 & 0 & 0 & 0 & 1 & 98 & 100 \\
\hline Hungary & Dél-Alföld & 0 & 1 & 0 & 2 & 1 & 0 & 0 & 94 & 100 \\
\hline Hungary & Észak-Alföld & 0 & 1 & 2 & 3 & 3 & 9 & 5 & 78 & 100 \\
\hline Italy & Emilia-Romagna & 0 & 1 & 5 & 5 & 14 & 12 & 21 & 41 & 100 \\
\hline Italy & Veneto & 0 & 9 & 3 & 18 & 10 & 11 & 12 & 37 & 100 \\
\hline Poland & Dolnoslaskie & 0 & 1 & 3 & 10 & 7 & 10 & 14 & 56 & 100 \\
\hline Romania & Nord-Est & 3 & 3 & 1 & 0 & 0 & 0 & 2 & 90 & 100 \\
\hline Romania & Centru & 1 & 2 & 5 & 5 & 6 & 9 & 13 & 60 & 100 \\
\hline Romania & Nord-Vest & 1 & 1 & 2 & 1 & 0 & 0 & 1 & 95 & 100 \\
\hline Romania & Vest & 0 & 1 & 0 & 0 & 0 & 0 & 0 & 93 & 100 \\
\hline Slovakia & Západné Slovensko & 0 & 0 & 0 & 0 & 0 & 0 & 1 & 99 & 100 \\
\hline Slovakia & Bratislavský kraj & 0 & 0 & 0 & 0 & 0 & 0 & 0 & 100 & 100 \\
\hline Slovakia & Stredné Slovensko & $n / a$ & $n / a$ & $\mathrm{n} / \mathrm{a}$ & $\mathrm{n} / \mathrm{a}$ & $\mathrm{n} / \mathrm{a}$ & $n / a$ & $\mathrm{n} / \mathrm{a}$ & $\mathrm{n} / \mathrm{a}$ & $n / a$ \\
\hline Spain & Castilla y León & 1 & 1 & 1 & 1 & 5 & 11 & 31 & 48 & 100 \\
\hline Spain & Andalucía & 0 & 2 & 0 & 9 & 5 & 14 & 18 & 51 & 100 \\
\hline Spain & País Vasco & 0 & 0 & 0 & 0 & 0 & 17 & 31 & 51 & 100 \\
\hline Spain & La Rioja & 0 & 0 & 0 & 7 & 4 & 21 & 39 & 29 & 100 \\
\hline Total VCS-MSs & $\begin{array}{l}\text { Largest of (maximum) four } \\
\text { regions c) }\end{array}$ & 0 & 1 & 3 & 9 & 8 & 11 & 14 & 54 & 100 \\
\hline Total EU-28 & & 0 & 0 & 1 & 4 & 4 & 8 & 18 & 65 & 100 \\
\hline
\end{tabular}




\section{Appendix 8 Standard Outputs (2010) of sugar beets and alternative crops in some important sugar beet production regions (VCS-MSs)}

\begin{tabular}{|c|c|c|c|c|c|c|c|c|}
\hline MS & Region & $\begin{array}{r}\text { Sugar } \\
\text { beet }\end{array}$ & $\begin{array}{r}\text { Common } \\
\text { wheat }\end{array}$ & $\begin{array}{l}\text { Durum } \\
\text { wheat }\end{array}$ & Barley & $\begin{array}{c}\text { Cereals } \\
\text { (total) }\end{array}$ & Rapeseed & Potatoes \\
\hline Croatia & Kontinentalna Hrvatska & 1,819 & 884 & 934 & 669 & 934 & 965 & 3,683 \\
\hline Czech Republic & Ceská republika & 1,993 & 826 & 826 & 735 & 826 & 1,060 & 3,799 \\
\hline \multirow[t]{3}{*}{ Finland } & Etelä-Karjala & 889 & 579 & & 499 & 579 & 458 & 4,421 \\
\hline & Keski-Suomi & 747 & 507 & & 405 & 507 & 404 & 2,787 \\
\hline & Helsinki-Uusimaa & 1,172 & 597 & & 585 & 597 & 487 & 3,118 \\
\hline \multirow[t]{2}{*}{ Greece } & Makedonia & 2,515 & 395 & 291 & 357 & 395 & 1,224 & 8,823 \\
\hline & Thessalia & 2,474 & 417 & 361 & 295 & 417 & 1,224 & 10,943 \\
\hline \multirow[t]{4}{*}{ Hungary } & Dél-Dunántúl & 1,935 & 724 & 780 & 586 & 780 & 947 & 4,779 \\
\hline & Közép-Dunántúl & 1,935 & 724 & 780 & 586 & 780 & 947 & 4,779 \\
\hline & Dél-Alföld & 1,939 & 612 & 767 & 508 & 767 & 771 & 4,650 \\
\hline & Észak-Alföld & 1,939 & 612 & 767 & 508 & 767 & 771 & 4,650 \\
\hline \multirow[t]{4}{*}{ Italy } & Emilia-Romagna & 3,262 & 1,386 & 1,721 & 988 & 1,721 & 716 & 12,083 \\
\hline & Veneto & 3,433 & 1,396 & 1,834 & 1,093 & 1,834 & 631 & 12,838 \\
\hline & Puglia & 2,741 & 683 & 842 & 508 & 842 & 499 & 8,583 \\
\hline & Lombardia & 2,416 & 1,308 & 1,718 & 1,032 & 1,718 & 672 & 8,484 \\
\hline Lithuania & Lietuva & 1,750 & 681 & & 447 & 681 & 731 & 2,384 \\
\hline \multirow[t]{3}{*}{ Poland } & Kujawsko-Pomorskie & 1,685 & 920 & & 640 & 920 & 974 & 2,683 \\
\hline & Lubelskie & 1,533 & 725 & & 574 & 725 & 841 & 2,013 \\
\hline & Dolnoslaskie & 1,685 & 920 & & 640 & 920 & 974 & 2,683 \\
\hline Romania & Romania & 1,245 & 530 & 394 & 456 & 530 & 613 & 3,121 \\
\hline \multirow[t]{2}{*}{ Slovakia } & Zapadne Slovensko & 1,552 & 777 & 718 & 728 & 777 & 969 & 2,453 \\
\hline & Bratislavsky & 1,772 & 605 & 886 & 609 & 886 & 941 & 3,503 \\
\hline \multirow[t]{4}{*}{ Spain } & Castilla y Leon & 3,038 & 675 & 615 & 554 & 675 & 575 & 5,251 \\
\hline & Andalucia & 2,487 & 542 & 622 & 368 & 622 & 363 & 6,941 \\
\hline & Pais Vasco & 2,882 & 1,113 & 517 & 761 & 1,113 & 695 & 4,810 \\
\hline & La Rioja & 2,704 & 834 & 803 & 659 & 834 & 733 & 5,443 \\
\hline
\end{tabular}

Source: Eurostat. 


\section{Appendix 9 Sugar beet yields in the EU in 2011 until 2015}

\begin{tabular}{|c|c|c|c|c|c|c|}
\hline \multirow[t]{2}{*}{ MS a) } & \multicolumn{6}{|c|}{ Sugar beet yield (tonnes/ha) in: } \\
\hline & 2011 & 2012 & 2013 & 2014 & 2015 & average \\
\hline Austria & 74.2 & 63.2 & 68.2 & 83.9 & 62.8 & 70.5 \\
\hline Belgium & 87.0 & 78.9 & 80.4 & 88.1 & 85.1 & 83.9 \\
\hline Bulgaria & 0.0 & 0.0 & 0.0 & 0.0 & 54.0 & 10.8 \\
\hline Croatia & 53.8 & 39.1 & 51.9 & 63.6 & 54.5 & 52.6 \\
\hline Cyprus & 0.0 & 0.0 & 0.0 & 0.0 & 0.0 & 0.0 \\
\hline Czech Republic & 66.8 & 63.3 & 60.0 & 70.3 & 59.4 & 64.0 \\
\hline Denmark & 67.5 & 64.9 & 52.5 & 59.6 & 67.5 & 62.4 \\
\hline Estonia & 0.0 & 0.0 & 0.0 & 0.0 & 0.0 & 0.0 \\
\hline Finland & 47.9 & 34.7 & 38.3 & 45.7 & 32.8 & 39.9 \\
\hline France & 96.9 & 86.6 & 85.7 & 93.3 & 87.0 & 89.9 \\
\hline Germany & 74.3 & 68.9 & 63.9 & 79.9 & 72.2 & 71.8 \\
\hline Greece & 58.9 & 54.0 & 58.6 & 68.3 & 52.3 & 58.4 \\
\hline Hungary & 56.5 & 47.1 & 52.6 & 69.2 & 58.7 & 56.8 \\
\hline Ireland & 0.0 & 0.0 & 0.0 & 0.0 & 0.0 & 0.0 \\
\hline Italy & 57.0 & 54.9 & 53.0 & 72.8 & 57.3 & 59.0 \\
\hline Latvia & 0.0 & 0.0 & 0.0 & 0.0 & 0.0 & 0.0 \\
\hline Lithuania & 49.9 & 52.2 & 54.6 & 59.7 & 50.6 & 53.4 \\
\hline Luxembourg & 0.0 & 0.0 & 0.0 & 0.0 & 0.0 & 0.0 \\
\hline Malta & 0.0 & 0.0 & 0.0 & 0.0 & 0.0 & 0.0 \\
\hline Netherlands & 79.9 & 78.6 & 78.5 & 91.0 & 83.3 & 82.2 \\
\hline Poland & 57.4 & 58.3 & 58.0 & 68.3 & 52.0 & 58.8 \\
\hline Portugal & 24.9 & 51.1 & 26.0 & 38.1 & 57.6 & 39.5 \\
\hline Romania & 35.1 & 26.4 & 36.6 & 44.7 & 39.1 & 36.4 \\
\hline Slovakia & 64.1 & 45.3 & 56.3 & 69.8 & 56.0 & 58.3 \\
\hline Slovenia & 0.0 & 0.0 & 0.0 & 0.0 & 0.0 & 0.0 \\
\hline Spain & 93.2 & 88.8 & 78.6 & 96.9 & 95.9 & 90.7 \\
\hline Sweden & 63.0 & 59.3 & 64.2 & 73.5 & 60.8 & 64.2 \\
\hline United Kingdom & 75.3 & 60.8 & 72.1 & 80.3 & 69.1 & 71.5 \\
\hline Total & 76.2 & 69.3 & 69.0 & 80.4 & 71.7 & 73.3 \\
\hline Total VCS-MSs & 60.9 & 56.7 & 56.8 & 69.0 & 56.7 & 60.0 \\
\hline
\end{tabular}

a) The ten countries with VCS support for sugar beet growing are marked in grey.

Source: Eurostat, adapted by Wageningen Economic Research. 


\section{Appendix 10 Regional indicators for evaluation of VCS-support in ten VCS-MSs}

\begin{tabular}{|c|c|c|c|c|c|c|c|c|c|c|c|c|c|c|c|c|}
\hline & \multirow[t]{4}{*}{ NUTS2 } & \multirow[t]{4}{*}{ Region name } & \multirow{4}{*}{$\begin{array}{r}\text { Number of } \\
\text { growers }\end{array}$} & \multirow{4}{*}{$\begin{array}{r}\text { Sugar beet } \\
\text { area (ha) }\end{array}$} & \multirow{4}{*}{$\begin{array}{r}\text { Sugar } \\
\text { beet } \\
\text { production } \\
(1,000 \\
\text { tonnes })\end{array}$} & \multirow{4}{*}{$\begin{array}{l}\text { VCS- } \\
\text { support } \\
\text { euro/ha) }\end{array}$} & \multirow{4}{*}{$\begin{array}{l}\text { Total } \\
\text { support } \\
\text { region } \\
(1,000 \\
\text { euro) }\end{array}$} & \multirow{2}{*}{\multicolumn{3}{|c|}{$\begin{array}{l}\text { Farm family Productivity } \\
\text { income 2012- (tonne/ha) }\end{array}$}} & \multicolumn{3}{|c|}{ Standard Outputs (euro/ha) } & \multirow{4}{*}{$\begin{array}{r}\text { VCS } \\
\text { (euro/ } \\
\text { tonnes } \\
\text { b) }\end{array}$} & \multirow{4}{*}{$\begin{array}{l}\text { Price in } 2015 \\
\text { (euro/tonne) }\end{array}$} & \multirow{4}{*}{$\begin{array}{r}\text { VCS } \\
\text { share } \\
(\%)\end{array}$} \\
\hline & & & & & & & & & & & Sugar c & Zereals & Rape & & & \\
\hline & & & & & & & & Value & National & & & & & & & \\
\hline & & & & & & & & & /regional & & & & & & & \\
\hline Croatia & HR04 & Kontinentalna Hrvatska & 870 & 20,250 & 1,051 & 121 & 2,450 & 5,200 & regional & 51.9 & 1,819 & 934 & 965 & 2.3 & 27.8 & 8.4 \\
\hline Czech Republic & CZO2 & Strední Cechy & 260 & 17,450 & 1,056 & 267 & 4,659 & 24,000 & national & 59.3 & 1,993 & 826 & 1,060 & 4.5 & 31.2 & 14.4 \\
\hline Czech Republic & CZO4 & Severozápad & 30 & 2,660 & 158 & 267 & 710 & 24,000 & national & 59.4 & 1,993 & 826 & 1,060 & 4.5 & 31.2 & 14.4 \\
\hline Czech Republic & CZO5 & Severovýchod & 270 & 16,460 & 985 & 267 & 4,395 & 24,000 & national & 59.8 & 1,993 & 826 & 1,060 & 4.5 & 31.2 & 14.3 \\
\hline Czech Republic & CZ06 & Jihovýchod & 70 & 5,680 & 324 & 267 & 1,517 & 24,000 & national & 57.0 & 1,993 & 826 & 1,060 & 4.7 & 31.2 & 15.0 \\
\hline Czech Republic & CZO7 & Strední Morava & 180 & 13,660 & 840 & 267 & 3,647 & 24,000 & national & 61.5 & 1,993 & 826 & 1,060 & 4.3 & 31.2 & 13.9 \\
\hline Czech Republic & CZ08 & Moravskoslezsko & 90 & 6,650 & 390 & 267 & 1,776 & 24,000 & national & 58.7 & 1,993 & 826 & 1,060 & 4.6 & 31.2 & 14.6 \\
\hline Finland & FI19 & Länsi-Suomi & 310 & 5,210 & 185 & 67 & 349 & 7,400 & regional & 35.6 & 1,040 & 644 & 481 & 1.9 & 31.1 & 6.1 \\
\hline Finland & FI1B & Helsinki-Uusimaa & 20 & 320 & - & 67 & 21 & 12,800 & national & 38.3 & 1,172 & 597 & 487 & 1.8 & 31.1 & 5.6 \\
\hline Finland & FI1C & Etelä-Suomi & 430 & 6,400 & 262 & 67 & 429 & 15,800 & regional & 41.0 & 1,059 & 617 & 498 & 1.6 & 31.1 & 5.3 \\
\hline Greece & EL11 & Anatoliki Makedonia, Thraki & 360 & 860 & 51 & 374 & 322 & 11,100 & national & 59.5 & 2,515 & 395 & 1,224 & 6.3 & 26.3 & 23.9 \\
\hline Greece & EL12 & Kentriki Makedonia & 740 & 2,200 & 129 & 374 & 823 & 12,400 & national & 58.8 & 2,515 & 395 & 1,224 & 6.4 & 26.3 & 24.1 \\
\hline Greece & EL13 & Dytiki Makedonia & 100 & 620 & 35 & 374 & 232 & 12,400 & national & 56.1 & 2,515 & 395 & 1,224 & 6.7 & 26.3 & 25.3 \\
\hline Greece & EL14 & Thessalia & 270 & 960 & 62 & 374 & 359 & 16,000 & regional & 64.7 & 2,474 & 417 & 1,224 & 5.8 & 26.3 & 22.0 \\
\hline Hungary & HU10 & Közép-Magyarország & 80 & 420 & 26 & 396 & 166 & 30,300 & national & 61.0 & 1,939 & 767 & 771 & 6.5 & 36.1 & 18.0 \\
\hline Hungary & $\mathrm{HU} 21$ & Közép-Dunántúl & 90 & 3,920 & 216 & 396 & 1,552 & 30,300 & national & 55.1 & 1,935 & 780 & 947 & 7.2 & 36.1 & 19.9 \\
\hline Hungary & $\mathrm{HU} 22$ & Nyugat-Dunántúl & 180 & 1,700 & 84 & 396 & 673 & 30,300 & national & 49.7 & 1,935 & 780 & 947 & 8.0 & 36.1 & 22.1 \\
\hline Hungary & $\mathrm{HU} 23$ & Dél-Dunántúl & 190 & 5,860 & 313 & 396 & 2,321 & 29,000 & regional & 53.4 & 1,935 & 780 & 947 & 7.4 & 36.1 & 20.6 \\
\hline Hungary & HU31 & Észak-Magyarország & 60 & 190 & 11 & 396 & 75 & 35,800 & regional & 57.6 & 1,895 & 726 & 673 & 6.9 & 36.1 & 19.1 \\
\hline Hungary & HU32 & Észak-Alföld & 220 & 2,770 & 143 & 396 & 1,097 & 30,400 & regional & 51.7 & 1,939 & 767 & 771 & 7.7 & 36.1 & 21.2 \\
\hline Hungary & HU33 & Dél-Alföld & 140 & 3,030 & 150 & 396 & 1,200 & 30,300 & national & 49.6 & 1,939 & 767 & 771 & 8.0 & 36.1 & 22.1 \\
\hline Italy & ITC1 & Piemonte & 300 & 1,940 & 48 & 276 & 535 & 22,700 & regional & 24.9 & 3,172 & 1,336 & 492 & 11.1 & 44.2 & 25.1 \\
\hline Italy & ITC4 & Lombardia & 360 & 2,220 & 31 & 276 & 613 & 20,600 & regional & 14.0 & 2,416 & 1,718 & 672 & 19.7 & 44.2 & 44.6 \\
\hline Italy & ITH3 & Veneto & 1,680 & 9,470 & 66 & 276 & 2,614 & 27,300 & regional & 7.0 & 3,433 & 1,834 & 631 & 39.4 & 44.2 & 89.2 \\
\hline
\end{tabular}




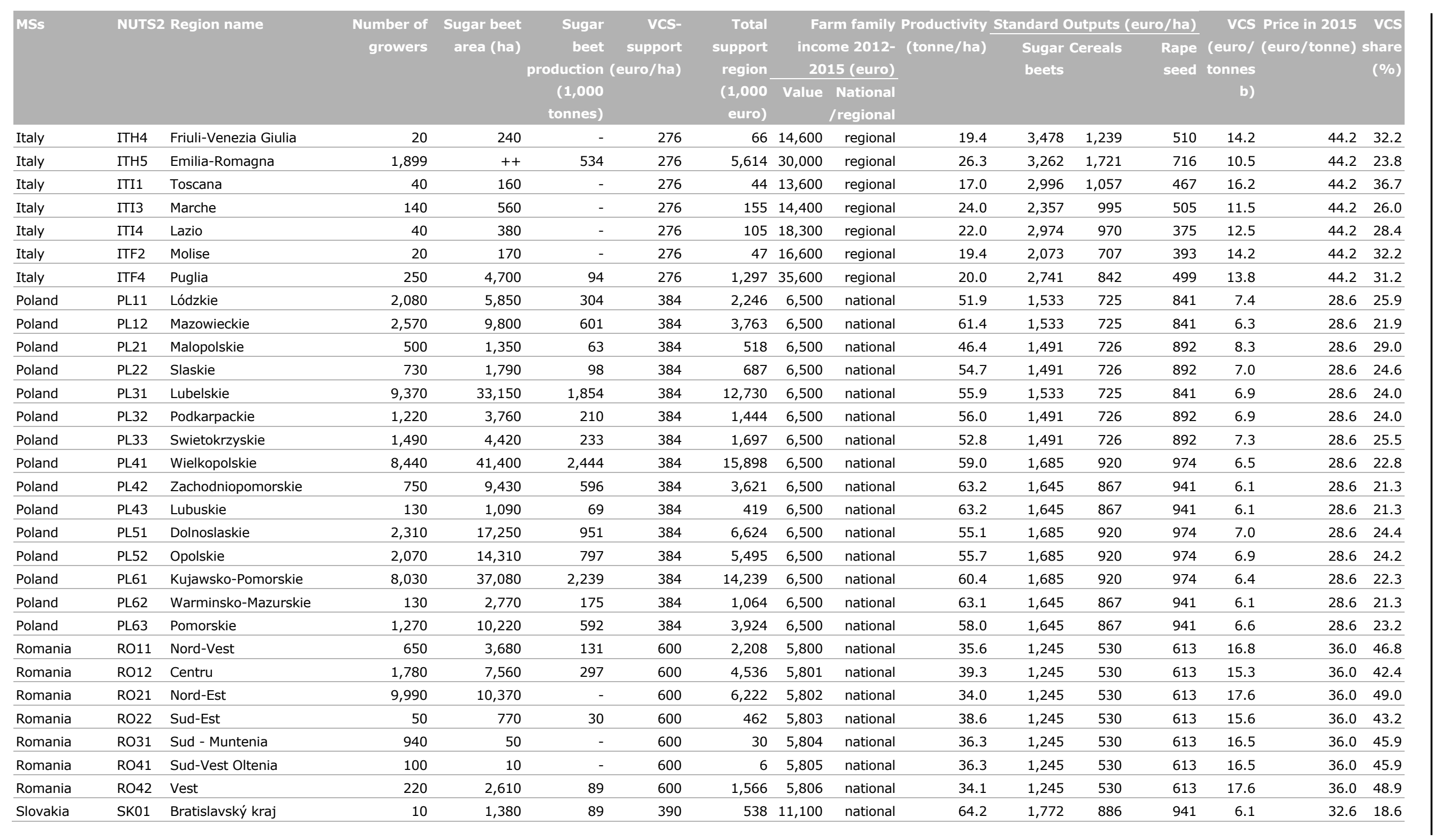




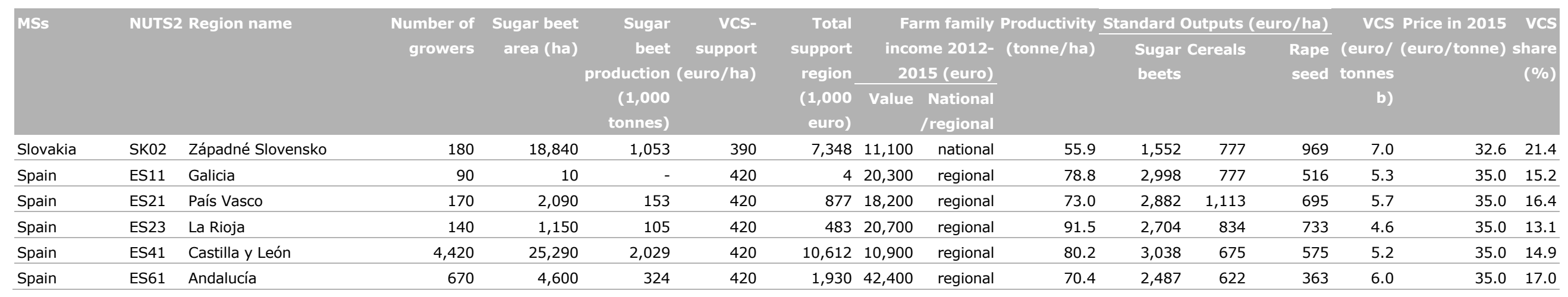


Wageningen Economic Research P.O. Box 29703

2502 LS The Hague

The Netherlands

$\mathrm{T}+31(0) 703358330$

E communications.ssg@wur.nl

www.wur.eu/economic-research

Wageningen Economic Research REPORT

2017-114
The mission of Wageningen University and Research is "To explore the potential of nature to improve the quality of life". Under the banner Wageningen University \& Research, Wageningen University and the specialised research institutes of the Wageningen Research Foundation have joined forces in contributing to finding solutions to important questions in the domain of healthy food and living environment. With its roughly 30 branches, 5,000 employees and 10,000 students, Wageningen University \& Research is one of the leading organisations in its domain. The unique Wageningen approach lies in its integrated approach to issues and the collaboration between different disciplines.

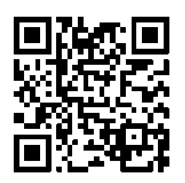





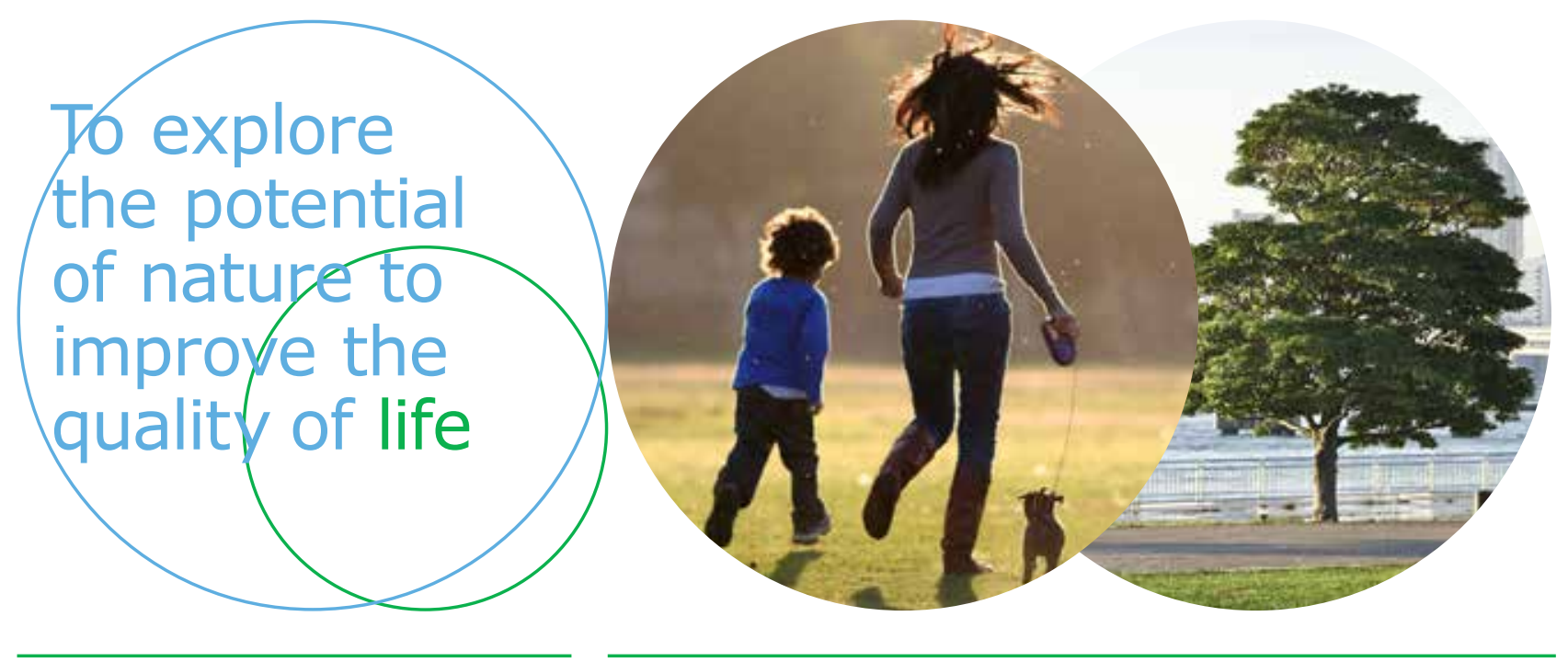

Wageningen Economic Research P.O. Box 29703

2502 LS Den Haag

The Netherlands

E communications.ssg@wur.nl www.wur.eu/economic-research

Report 2017-114

ISBN 978-94-6343-243-6
The mission of Wageningen University and Research is "To explore the potential of nature to improve the quality of life". Under the banner Wageningen University \& Research, Wageningen University and the specialised research institutes of the Wageningen Research Foundation have joined forces in contributing to finding solutions to important questions in the domain of healthy food and living environment. With its roughly 30 branches, 5,000 employees and 10,000 students, Wageningen University \& Research is one of the leading organisations in its domain. The unique Wageningen approach lies in its integrated approach to issues and the collaboration between different disciplines. 